\title{
\#USGS
}

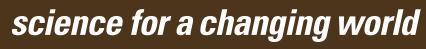

Anatomical and Genetic Variation of Western Oxyloma (Pulmonata: Succineidae) Concerning the Endangered Kanab Ambersnail (Oxyloma haydeni kanabense) in Arizona and Utah

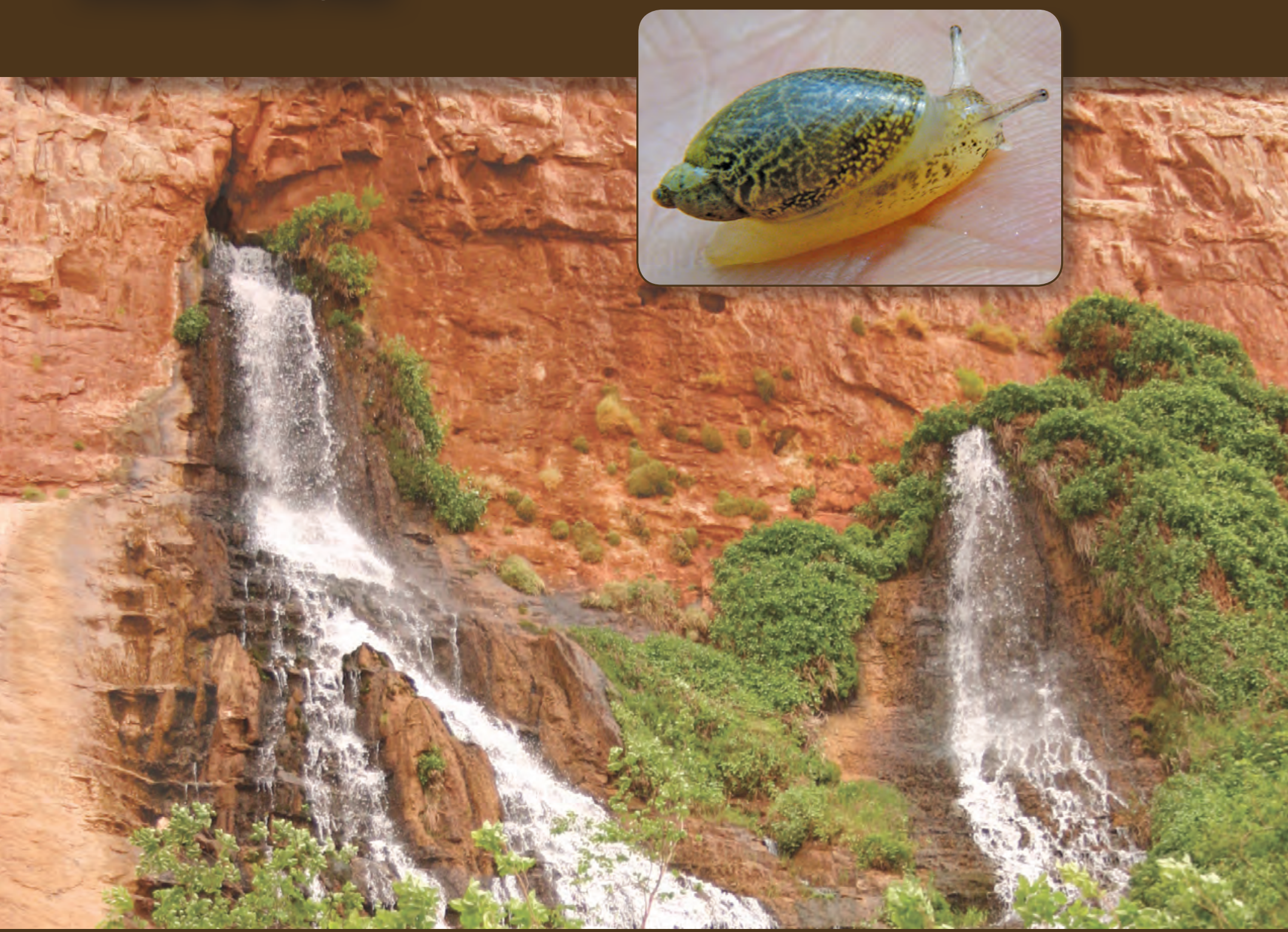

Scientific Investigations Report 2013-5164 
Cover:

Foreground photograph: Kanab ambersnail (Oxyloma haydeni kanabense).

Background photograph: Vasey's Paradise waterfalls, Colorado River, Arizona.

Photograph taken by Jeff Sorensen, Arizona Game and Fish Department. 


\section{Anatomical and Genetic Variation of Western Oxyloma (Pulmonata: Succineidae) Concerning the Endangered Kanab Ambersnail (Oxyloma haydeni kanabense) in Arizona and Utah}

By Melanie Culver, Hans-Werner Herrmann, Mark Miller, Barry Roth, and Jeff Sorenson

Scientific Investigations Report 2013-5164 


\title{
U.S. Department of the Interior SALLY JEWELL, Secretary
}

\section{U.S. Geological Survey \\ Suzette M. Kimball, Acting Director}

\author{
U.S. Geological Survey, Reston, Virginia: 2013
}

For more information on the USGS - the Federal source for science about the Earth, its natural and living resources, natural hazards, and the environment, visit http://www.usgs.gov or call 1-888-ASK-USGS.

For an overview of USGS information products, including maps, imagery, and publications, visit http://www.usgs.gov/pubprod

To order this and other USGS information products, visit http://store.usgs.gov

Any use of trade, firm, or product names is for descriptive purposes only and does not imply endorsement by the U.S. Government.

Although this information product, for the most part, is in the public domain, it also may contain copyrighted materials as noted in the text. Permission to reproduce copyrighted items must be secured from the copyright owner.

Suggested citation:

Culver, Melanie, Herrmann, Hans-Werner, Miller, Mark, Roth, Barry, and Sorenson, Jeff, 2013, Anatomical and genetic variation of western Oxyloma (Pulmonata: Succineidae) concerning the endangered Kanab ambersnail (Oxyloma haydeni kanabense) in Arizona and Utah: U.S. Geological Survey Scientific Investigations Report, 2013-5164, 66 p., http://pubs.usgs.gov/sir/2013/5164/. 


\section{Contents}

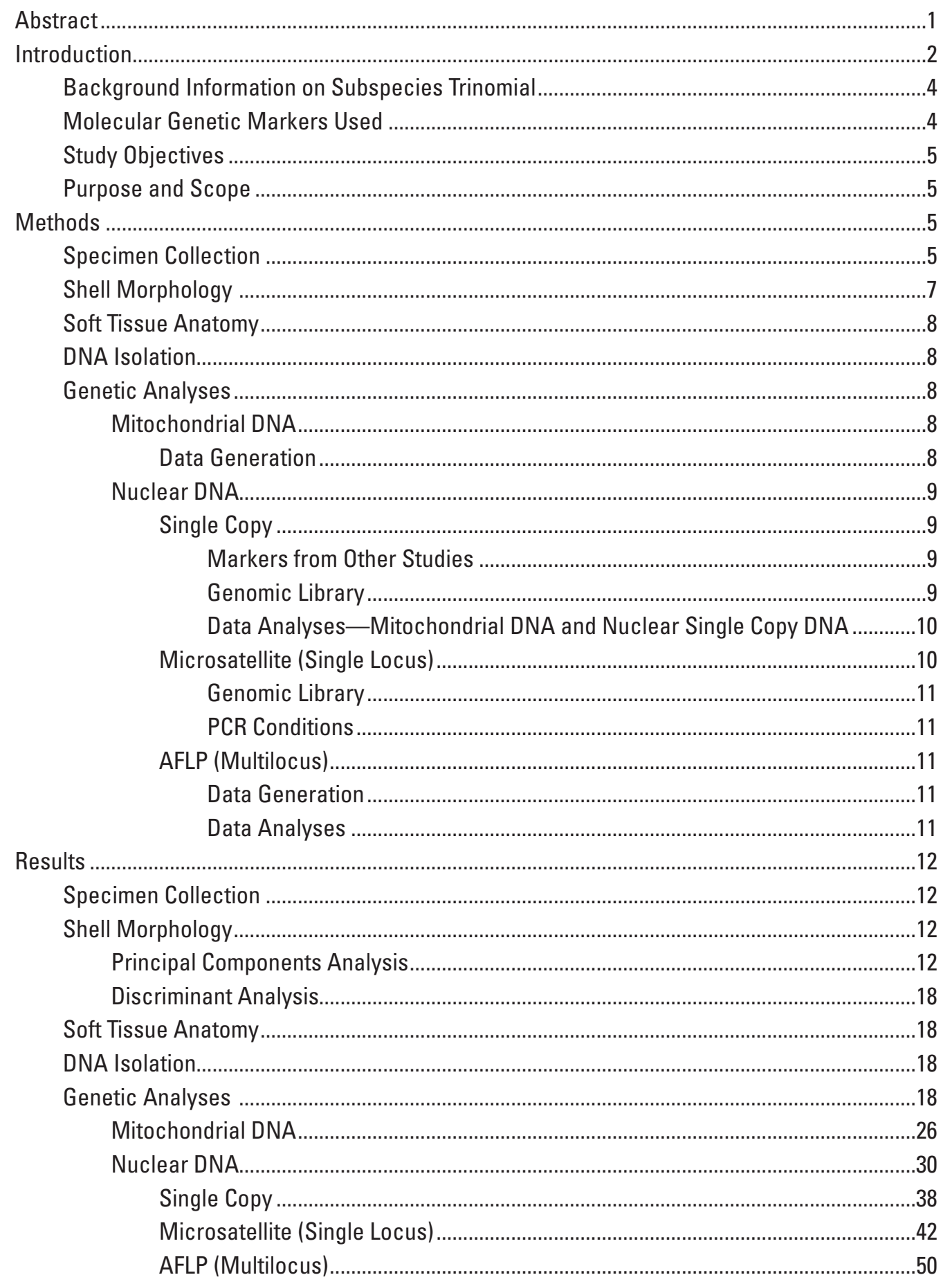




\section{Contents-Continued}

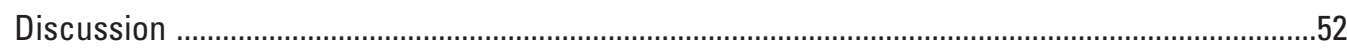

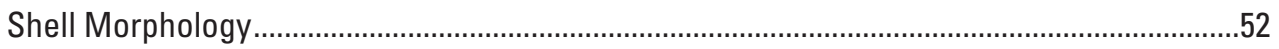

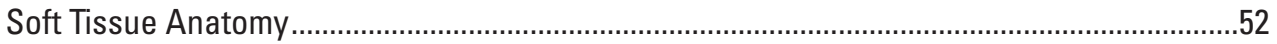

Morphology and Anatomy_-Taxonomic-Nomenclatural Considerations..............................53

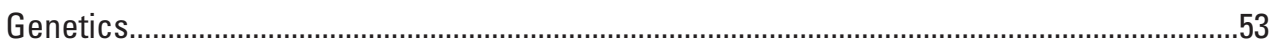

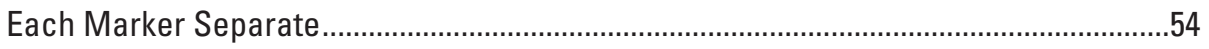

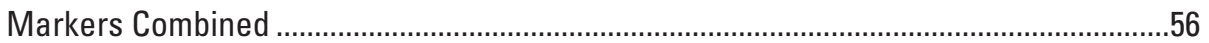

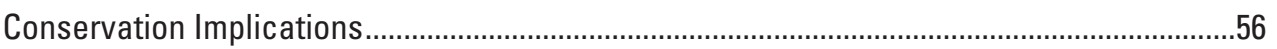

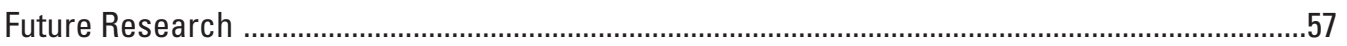

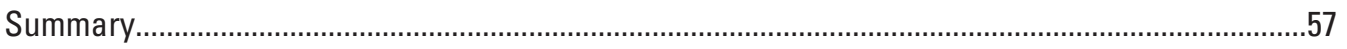

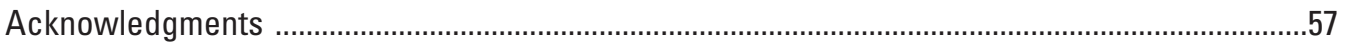

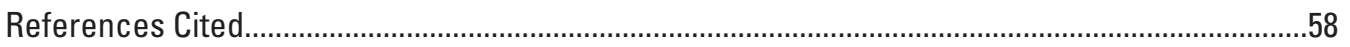

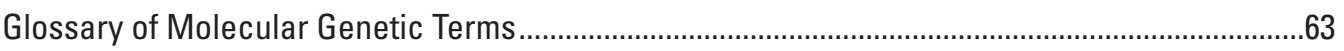

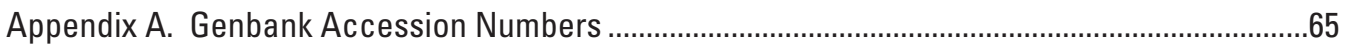

Appendix B. DNA Sequences for Random Ambersnail Nuclear Clone 356 ……............................65

Appendix C. DNA Sequences for Ribosomal First and Second Internal Transcribed Spacer.......65

\section{Figures}

1. Map showing sampling locations for Oxyloma populations used in this study from Arizona and Utah

2. Graph showing scores of Oxyloma specimens from all study samples in Arizona and Utah on principal components 2 and 3 ("factors") from principal components analysis

3. Graphs showing scores of Oxyloma specimens from individual sampling locations in Arizona and Utah on principal components 2 and 3 ("factors") from principal components analysis

4. Graphs showing scores of Oxyloma specimens from sampling locations in Arizona and Utah individually on principal components 3 and 4 ("factors") from principal components analysis

5. Canonical scores plot of discriminant analysis using shell dimension variables SL (shell length), SD (shell maximum diameter), SAL (shell aperture length), SAW (shell aperture width), and SMD (height of maximum diameter).

6. Diagram showing anatomical features for Oxyloma specimens analyzed for this study.

7. Maximum likelihood tree diagram showing the concatenated mitochondrial DNA dataset (mtconcat) including the cytochrome oxidase subunit I (COI) and cytochrome $b$ (cyt $b$ ) genes for Oxyloma populations, used to show position of the outgroups. 


\section{Figures-Continued}

8. Bayesian (MB) 50-percent majority rule consensus tree diagram showing mitochondrial cytochrome oxidase subunit I gene (COI) dataset analyzed for Oxyloma populations sampled.

9. Median-joining haplotype network diagram showing mitochondrial cytochrome oxidase subunit I gene (COI) dataset analyzed for Oxyloma populations sampled.........32

10. Bayesian 50-percent majority rule consensus tree diagram showing mitochondrial cytochrome $b$ gene (cyt b) dataset analyzed for Oxyloma populations sampled ............34

11. Median-joining haplotype network diagram showing mitochondrial cytochrome b gene (cyt $b$ ) dataset analyzed for Oxyloma populations sampled.

12. Bayesian 50-percent majority rule consensus tree diagram showing concatenated mitochondrial DNA dataset (mtconcat) including the cytochrome oxidase subunit I (COI) and cytochrome $b$ (cyt $b$ ) genes analyzed for Oxyloma populations sampled.......37

13. Median-joining haplotype network drawing showing concatenated mitochondrial DNA dataset (mtconcat) including the cytochrome oxidase subunit I (COI) and cytochrome $b$ (cyt $b$ ) genes analyzed for Oxyloma populations sampled.

14. Bayesian 50-percent majority rule consensus tree diagram showing ribosomal gene introns S7-1 and S7-2 (S7) dataset analyzed for Oxyloma populations sampled...39

15. Median joining haplotype network diagram showing ribosomal gene introns S7-1 and S7-2 (S7) dataset analyzed for Oxyloma populations sampled. S7 partial 1 and 2 (below the main network) represent magnified parts of the complete network

16. Bayesian 50-percent majority rule consensus tree diagram of the ribosomal DNA first and second internal transcribed spacer (ITS) dataset analyzed for Oxyloma populations sampled

17. Bayesian 50-percent majority rule consensus tree diagram showing random ambersnail nuclear clone 356 (356) dataset analyzed for Oxyloma populations sampled

18. Median-joining haplotype network diagram showing random ambersnail nuclear clone 356 (356) dataset analyzed for Oxyloma populations sampled

19. Bayesian 50-percent majority rule consensus tree diagram showing random ambersnail nuclear clone 458 (458) dataset analyzed for Oxyloma populations sampled.

20. Median-joining haplotype network diagram showing random ambersnail nuclear clone 458 (458) dataset analyzed for Oxyloma populations sampled.

21. Diagram showing nuclear microsatellite alleles present in each individual, indicated by cells with allele sizes listed across columns and individuals listed down rows

22. Unweighted Pair Group Method with Arithmetic mean (UPGMA) tree diagram showing Amplified Fragment Length Polymorphism (AFLP) data analyzed for Oxyloma populations sampled.

23. Diagram showing results of a Bayesian STRUCTURE analysis of the Amplified Fragment Length Polymorphism (AFLP) data analyzed for Oxyloma populations sampled 


\section{Tables}

1. Site name and locality description of ambersnail populations in Arizona and Utah sampled for the anatomical and genetic analyses described in this study...

2. Number of ambersnail samples per population in Arizona and Utah, sequenced for two mitochondrial DNA (mtDNA) loci, the concatenated mtDNA loci, the four nuclear DNA loci, and the Amplified Fragment Length Polymorphism (AFLP) analyses

3. Polymerase Chain Reaction (PCR) primer sequences used for PCR amplification and the appropriate PCR annealing temperatures for each of the five nuclear loci used in this study of Oxyloma populations

4. Summary statistics of ambersnail shell morphology variables used in principal components analysis and discriminant analysis, by sample localities in Arizona and Utah

5. Pearson correlation pairwise matrix for ambersnail shell characters submitted to principal components analysis and discriminant analysis used to analyze Oxyloma populations

6. Component loadings of variables measured in 0xyloma populations, eigenvalues, and percent of total variance explained by the first four components in principal components analysis of shells of Oxyloma

7. Summary of Oxyloma anatomical data collected for this study, by sample localities in Arizona and Utah....

8. Analysis of molecular variance used to estimate genetic variation within versus among populations; and Mantel test to assess correlation between genetic distance and geographic distance for six different mitochondrial and nuclear DNA loci and one concatenated mtDNA dataset used to analyze genetic variation in Oxyloma populations.

9. Tajima's $D$ (a test for demographic expansion or contraction) values for 6 mitochondrial and nuclear DNA loci and 1 concatenated mitochondrial DNA region in 12 Oxyloma populations from Arizona and Utah

10. Fu's $F$ statistic (a test for population expansion) for 6 mitochondrial and nuclear DNA loci and 1 concatenated mitochondrial DNA region in 12 Oxyloma populations from Arizona and Utah.

11. Roza's $R^{2}$ value (a test for population growth) for 6 mitochondrial and nuclear DNA loci, 1 concatenated mitochondrial DNA region, and 1 concatenated nuclear DNA region in 12 Oxyloma populations from Arizona and Utah

12. Pairwise distance matrices for mitochondrial DNA datasets for Oxyloma populations from Arizona and Utah 


\section{Conversion Factors}

Inch/Pound to SI

\begin{tabular}{ccc}
\hline Multiply & By & To obtain \\
\hline cubic foot per second $\left(\mathrm{ft}^{3} / \mathrm{s}\right)$ & Flow rate & \\
\hline
\end{tabular}

SI to inch/pound

\begin{tabular}{lcl}
\hline \multicolumn{1}{c}{ Multiply } & \multicolumn{1}{c}{ By } & \multicolumn{1}{c}{ To obtain } \\
\hline & Length \\
\hline millimeter $(\mathrm{mm})$ & 0.03937 & inch (in.) \\
kilometer $(\mathrm{km})$ & 0.6214 & mile (mi) \\
\hline \multicolumn{3}{c}{ Volume } \\
\hline microliter $(\mu \mathrm{L})$ & 0.000034 & ounce, fluid (fl. oz) \\
\hline \multicolumn{3}{c}{ Mass } \\
\hline gram $(\mathrm{g})$ & 0.03527 & ounce, avoirdupois (oz) \\
\hline
\end{tabular}

Temperature in degrees Celsius $\left({ }^{\circ} \mathrm{C}\right)$ may be converted to degrees Fahrenheit $\left({ }^{\circ} \mathrm{F}\right)$ as follows:

${ }^{\circ} \mathrm{F}=\left(1.8 \times{ }^{\circ} \mathrm{C}\right)+32$. 
This page intentioanlly left blank. 


\title{
Anatomical and Genetic Variation of Western Oxyloma (Pulmonata: Succineidae) Concerning the Endangered Kanab Ambersnail (Oxyloma haydeni kanabense) in Arizona and Utah
}

\author{
By Melanie Culver ${ }^{1}$, Hans-Werner Herrmann'ㄹ, Mark Miller ${ }^{3}$, Barry Roth ${ }^{4}$, and Jeff Sorenson ${ }^{5}$
}

\section{Abstract}

The land snail genus Oxyloma (Pulmonata: Succineidae) includes the Federally endangered Kanab ambersnail (Oxyloma haydeni kanabense Pilsbry), which is known at the time of this study from only two locations in the United States: Three Lakes, Utah, and Vaseys Paradise, Arizona, on the Colorado River in Grand Canyon National Park. Since 1994, the Kanab ambersnail has received much attention because its presence at Vaseys Paradise has implications for the ecosystem-wide management of the Colorado River. This attention is primarily because an experimental high-flow release of water from Glen Canyon Dam in 1996 destroyed or degraded Kanab ambersnail habitat at Vaseys Paradise. This experimental high flow was designed to replicate natural flow regimes throughout the Grand Canyon river corridor. However, as a result of the habitat destruction at Vaseys Paradise, in 1996, the U.S. Fish and Wildlife Service ruled that no further experimental high-discharge floods could be carried out until additional Kanab ambersnail populations were discovered or established. This mandate created a situation where the management of a single endangered species conflicted directly with the management of an entire ecosystem. Although since 1996, the U.S. Fish and Wildlife Service has permitted the use of flows as high as stage heights equivalent to 44,000 cubic feet per second, higher flows were requested by various Grand Canyon stakeholders and scientists but were not possible owing to low storage of Lake Powell.

\footnotetext{
${ }^{1}$ U.S. Geological Survey, Arizona Cooperative Fish and Wildlife Research Unit and University of Arizona, School of Natural Resources and the Environment, Tucson.

${ }^{2}$ University of Arizona, Department of Plant Sciences, Tucson.

${ }^{3}$ U.S. Geological Survey, Forest and Rangeland Ecosystem Science Center, Corvallis, Oregon.

${ }^{4}$ Consultant, San Francisco.

${ }^{5}$ Arizona Game and Fish Department, Phoenix.
}

Adding to the controversy about Oxyloma and the Kanab ambersnail were previous anatomical and genetic analyses of the genus, which showed that genetic characteristics of specimens did not correspond with their identifications based on traditional taxonomic criteria, raising questions about the validity of the taxonomy of Oxyloma and the protected status of Kanab ambersnails. Specifically, a previous study suggested that the endangered Kanab ambersnail population at Three Lakes was more closely related to other, non-endangered ambersnail populations across the Southwest. In contrast, the Kanab ambersnail population at Vaseys Paradise appeared to be genetically distinct from all other ambersnail populations studied.

Management options for the ambersnail population at Vaseys Paradise, at the time of this study, conflict with ecosystem-wide measures proposed to benefit other natural resources in the Grand Canyon. The U.S. Fish and Wildlife Service will not revise the 1995 Kanab Ambersnail Recovery Plan until further genetic and anatomical analyses provide more fine-scale taxonomic resolution of the identity of Oxyloma populations on the Colorado Plateau and elsewhere in the American Southwest. Likewise, interagency cooperators cannot revise down-listing criteria for the Kanab ambersnail until substantial evidence is provided identifying distinct Oxyloma taxa or a larger group of conspecifics that reasonably could be managed as one species. Therefore, given the current controversy about the taxonomy of Oxyloma and the endangered Kanab ambersnail, new detailed analyses were completed of morphological and genetic variation from many Oxyloma specimens collected at 12 western North American locations. These new data have allowed us to evaluate many issues related to Kanab ambersnail taxonomy. Using this dataset, the study of shells and anatomy indicates that the holotype of Oxyloma haydeni kanabense plausibly can be regarded as a member of the same species as the populations of Oxyloma analyzed in this study. Additionally, the presence of gene flow among all populations is evidence that they are members of the same species. Almost all the observed genetic diversity can be accounted for by short-distance or 
long-distance dispersal events between populations in this study. Our major taxonomic conclusion is that all samples collected for this study were drawn from populations of the same species.

\section{Introduction}

The land snail genus Oxyloma (Pulmonata: Succineidae) contains about 16 described taxa throughout the United States and Canada (Pilsbry and Ferris, 1911; Pilsbry, 1948; Turgeon and others, 1998) and includes the federally endangered Kanab ambersnail (Oxyloma haydeni kanabense Pilsbry). (Note: Although it is spelled "kanabensis" in most of the literature, this taxon name should be "kanabense" to agree in gender with the neuter noun Oxyloma [Turgeon and others, 1998]. Similarly, Oxyloma nuttalliana and O. retusa should be $O$. nuttallianum and $O$. retusum, respectively.)

The taxon Oxyloma haydeni kanabense Pilsbry previously has been recognized at only two locations: Three Lakes, Utah, and Vaseys Paradise, Arizona, on the Colorado River in Grand Canyon National Park (fig. 1). It is protected under the Endangered Species Act as an endangered subspecies (U.S. Fish and Wildlife Service, 1992a and 1992b), although some consider it deserves full species status (Oxyloma kanabense: Harris and Hubricht, 1982; Spamer and Bogan, 1993). The Kanab ambersnail purportedly differs from other Oxyloma in its shell morphology, whose "spire is more slender and drawn out than O. haydeni” (Pilsbry, 1948), and reproductive anatomy (genitalia). According to Pilsbry (1948), "the genitalia show some resemblance to $O$. nuttalliana, but this species differs by the short penis, more coiled epiphallus, the twinned seminal vesicles and (in the specimen dissected), the massive hermaphroditic duct.” There are many cases where the U.S. Fish and Wildlife Service (USFWS) is uncertain whether a group of populations should be classified as a subspecies or a species, and this issue is controversial (Scott and others, 2006). The term "evolutionarily significant unit (ESU)" is sometimes used to describe the same level of population divergence as a typical subspecies, so subspecies and ESU are often used synonymously (Moritz, 1994).

Since 1994, the Kanab ambersnail has received much attention because its presence at Vaseys Paradise has implications for the ecosystem-wide management of the Colorado River. In 1996, an experimental high-water discharge from Glen Canyon Dam destroyed or degraded about 17 percent of Kanab ambersnail habitat at Vaseys Paradise (Stevens and others, 2001). This planned flood release was designed to let resource managers evaluate an alternate strategy for Glen Canyon Dam operations and to allow the restoration of more natural flow regimes throughout the Grand Canyon river corridor. The ultimate goal was to mimic natural floods that occurred in the canyon prior to the completion of the dam in 1963. As a result of the habitat destruction at Vaseys Paradise in 1996, the USFWS ruled that no further experimental high-flows could be done until additional Kanab ambersnail populations were discovered or established (U.S. Fish and Wildlife Service, 1996, 1997). This mandate created a situation where the management of a single endangered species conflicted directly with the management of an entire ecosystem (Meretsky and others, 2000). Although since 1966, the USFWS permitted the use of flows as high as stage heights equivalent to 44,000 cubic feet per second (U.S. Fish and Wildlife Service, 1996, 1997), various Grand Canyon stakeholders and scientists requested higher flows. These higher flows, although potentially beneficial to the Grand Canyon ecosystem, would result in habitat destruction at Vaseys Paradise. Until the USFWS declares a new Finding of No Significant Impact for the High Flow Equivalent protocol Environmental Assessment, it is not clear what they find acceptable, although the USFWS has allowed three tests of that magnitude since the Environmental Impact Statement was completed.

In previous work on the genus Oxyloma (Miller and others, 2000), Amplified Fragment Length Polymorphism (AFLP) markers and deoxyribonucleic acid (DNA) sequences were used to characterize genetic diversity in southwestern Oxyloma populations. This analysis was performed on individuals from the two known Kanab ambersnail populations and individuals from the only two known southwestern populations of the widespread, non-endangered, Niobrara ambersnail (Oxyloma haydeni haydeni) from Indian Garden, in Grand Canyon National Park, and the Minus 9-Mile Spring, upstream of Lees Ferry on the Colorado River. A controversial result of this analysis was the indication that the Kanab ambersnail population at Three Lakes is closely related to the non-endangered Niobrara ambersnail population at Indian Garden. Additionally, the Vaseys Paradise population appeared to be distinct from the other three populations. These findings raised multiple questions about the taxonomic status of the Kanab ambersnail and its protected status under the Endangered Species Act.

Because of the conflicting morphological and molecular genetic information from Miller and others (1996) and Stevens and others (2000) on the evolution of the genus Oxyloma, a discrepancy existed, as the actual taxonomic and conservation status of the Kanab ambersnail was unclear. As a result of this discrepancy, efforts were made to locate additional southwestern populations of Oxyloma, and field surveys identified many new populations of the genus throughout the Southwest (Meretsky and others, 2002). 


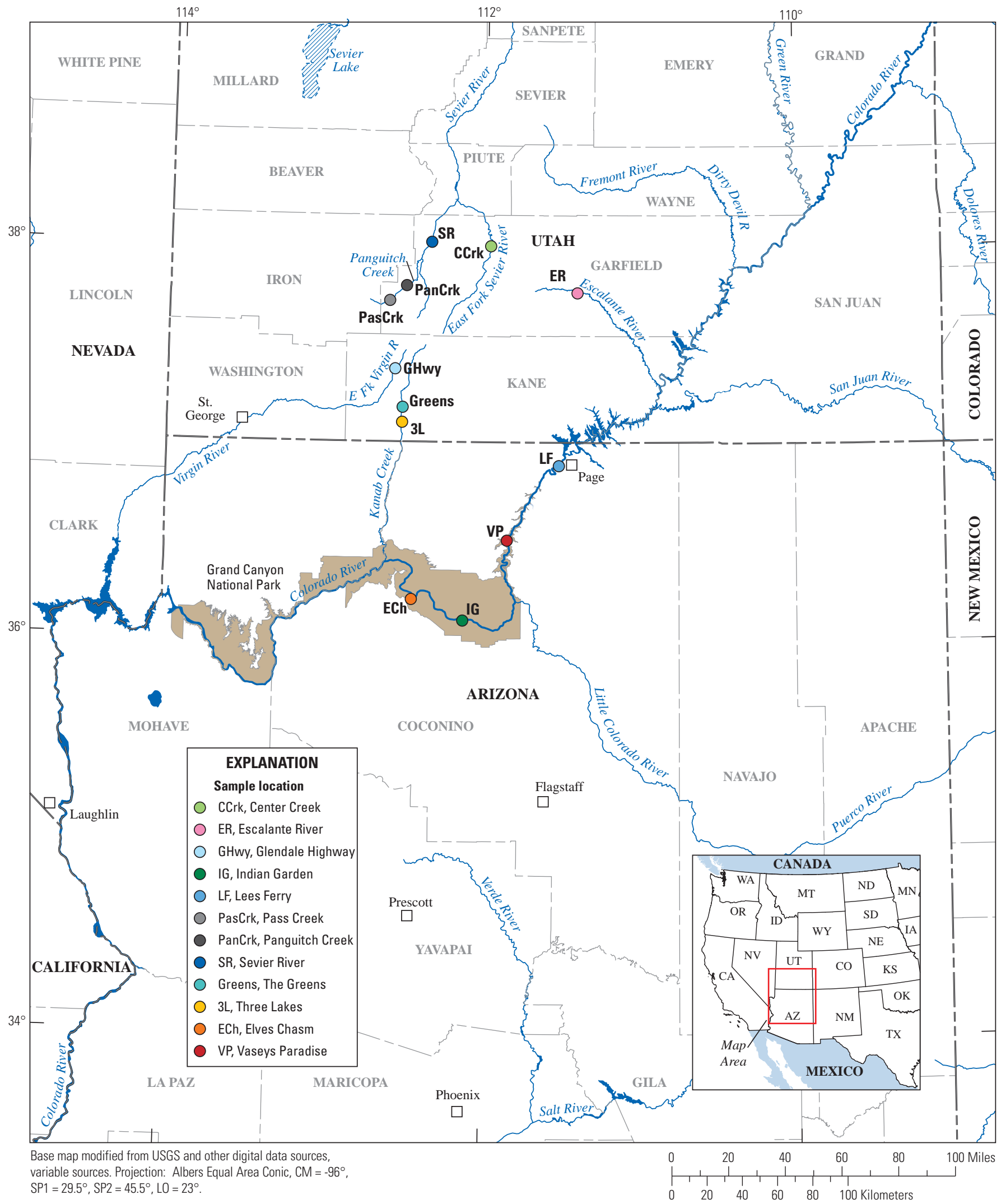

Figure 1. Sampling locations for Oxyloma populations used in this study from Arizona and Utah. Each location is coded with a different color. These colors are consistent for those same populations in the phylogenetic trees figures. 
Given the discovery of new Oxyloma populations, Stevens and others (2000) conducted new analyses of anatomical and mitochondrial genetic variation (cytochrome $b$, $c y t b$ ) in succineids from across western North America. These analyses corroborated findings of the previous study by Stevens and others (2000) in that taxonomic designations of Oxyloma specimens did not correspond with their mitochondrial haplotypes. For example, the Kanab ambersnail population at Three Lakes and the Niobrara ambersnail population at Indian Garden (Haplotype BB), when included with a sample of a more diverse set of populations, continued to form part of the same evolutionary clade. Similarly, the Vaseys Paradise population, which seemed distinct from the other three populations previously studied, appeared in its own basal group outside the other Oxyloma specimens included in analyses. This suggested that the Vaseys Paradise population diverged from other Oxyloma populations early in the evolutionary history of the genus in western North America. Interestingly, whereas the Kanab ambersnail population at Three Lakes seemed closely related to other newly discovered southwestern Oxyloma populations, the anatomical studies indicated that none of the new populations contained Kanab ambersnails. Instead, individuals identified as $O$. haydeni haydeni and $O$. retusum seemed closely related to specimens from the Three Lakes population.

\section{Background Information on Subspecies Trinomial}

Because the Kanab ambersnail was listed under the Endangered Species Act as a subspecies, it is relevant to give some background information on the issue of subspecies, particularly with respect to conservation. The term

"subspecies," as a Latin trinomial, was introduced by Esper to designate geographical varieties (Mayr, 1982). In 1942, Mayr defined a subspecies as "a geographically defined aggregate of local populations which (sic) differ taxonomically from other subdivisions of the species." However, Wilson and Brown (1953) dismissed the subspecies trinomial as arbitrary, too subjective to be useful, a taxonomic designation that is often based on insignificant groupings or clines, and widely exploited. In 1981, with the emergence of conservation biology as a science and the legal incorporation of subspecies into the Endangered Species Act, debate over subspecies was revived at an ornithological forum (Barrowclough, 1982; Gill, 1982; Mayr, 1982). Later, Avise and Ball (1990) suggested that subspecies designations should be made based on "concordant distribution of multiple independent genetic traits," and that this would reduce the subjective and arbitrary nature of trinomials. Subsequent to Avise and Ball's definition, O'Brien and Mayr (1991) proposed that members of a subspecies would share (1) a unique geographic range, (2) a set of "phylogenetically concordant phenotypic characters," (3) a suite of molecular genetic similarities, and (4) derived adaptations relative to other subspecies. Furthermore, a subspecies could (1) go extinct, (2) become a new subspecies by hybridization with another subspecies, (3) become a new subspecies by changing its genetic character through stochastic processes like genetic drift, (4) become a new species by becoming reproductively isolated such as by developing intrinsic barriers, or (5) remain the same. Subspecies should be on their own "evolutionary trajectory," not yet reproductively isolated but with the future potential to be isolated, as suggested by Moritz (1994) in his development of the Evolutionarily Significant Unit (ESU) concept; many systematists use the term ESU synonymously with subspecies.

\section{Molecular Genetic Markers Used}

With the advance of molecular markers, in the 1990s, as a high-resolution tool to determine phylogenetically distinguishable intraspecific populations, molecular markers have revealed that subspecific taxonomy does not always represent evolutionary relationships (Avise and Ball, 1990; O’Brien and Mayr 1991). Additionally, the results of phylogenetic reconstruction with one gene do not always agree with the results of phylogenetic reconstruction with another gene, and results with one gene can differ among species (Avise, 1991; Graur and Li, 2000). Therefore, several different genes and several independent markers were selected for this study.

The first class of markers used here is mitochondrial DNA (mtDNA) genes. The mtDNA genome does not recombine and is inherited maternally (Brown, 1983; Harrison, 1989; Gyllensten and others, 1991). Additionally, the mtDNA genome is rapidly evolving, making it useful in examining recently diverged populations (Brown, 1985; Wilson and others, 1985; Moritz and others, 1987; Avise, 1991). The second class of markers used is nuclear microsatellite DNA. These markers, composed of tandem repeats of 1-6 base pair (bp) units, are highly polymorphic nuclear markers that are randomly distributed throughout the genome (Weber, 1993; Tautz and others, 1986; Tautz, 1989; Edwards and others, 1992). Because microsatellites have high levels of polymorphism, they are ideal for examining populations within a species. The next class of molecular markers is nuclear DNA sequence for genes and random regions. The nuclear DNA sequences complement the mtDNA because they are inherited bi-parentally instead of maternally. The final marker used in this study is Amplified Fragment Length Polymorphisms (AFLP), which is a multilocus marker that simultaneously can type hundreds of loci across the genome. The advantage of AFLPs is their ability to sample broadly across the nuclear genome of the organism. Each marker is characterized by distinct rates of evolution and thereby possesses different levels of resolution from resulting data and analyses, and was selected to analyze recent divergences. 


\section{Study Objectives}

The main objective of this study was to obtain additional information to help resolve the controversial Oxyloma haydeni taxa at the species and subspecies-population level. The first step in resolving differences among datasets required a thorough understanding of the anatomical variation used at the time of this study to distinguish taxa and to designate conservation units. This step is essential, given that previous anatomical analyses of southwestern Oxyloma were performed on very small sample sizes (1-3 individuals) from each location (Stevens and others, 2000). Furthermore, in the course of performing the new anatomical work, tissue samples were preserved separately and used to obtain DNA for genetic and molecular evolutionary analyses of nuclear and mitochondrial genetic variation. This provided an unprecedented opportunity to generate molecular and morphologic datasets from an identical array of specimens. We sampled a relatively large number of individuals (about 20) within each of 12 populations. Generation of these new genetic data, along with the new anatomical information, allowed us to address the following questions:

1. What are the extent and nature of anatomical variation among individuals within populations?

2. Does the anatomical variation within populations appear to reflect the presence of one or more species at a location?

3. Do anatomical investigations tend to confirm the taxonomic significance of structures originally regarded as significant by Pilsbry (1948), or do other anatomical characters better reflect the evolutionary history of Oxyloma in the western United States?

4. Does the previous pattern observed in Stevens and others (2000) hold when large numbers of individuals from each location are used for analyses?

5. Do the genetic data suggest the presence of distinct evolutionary lineages within and among populations?

6. Do the genetic data, when interpreted as a whole along with data from analyses of anatomical variation, suggest that one of the three hypotheses described in questions 2 , 3 , or 4 is likely correct?

Question 1 is observational; questions 2, 3, and 4 are interpretive. Interpretations of explicit criteria have been made for species definitions (Roth, 2004).

\section{Purpose and Scope}

This report documents all known land snail populations of the genus Oxyloma in Arizona and Utah and examines taxonomic distinctions among populations. Additional taxonomic considerations at the subspecies level are discussed as relevant to the Kanab ambersnail. The Kanab ambersnail was listed as federally endangered in 1992, and the endangered subspecies is thought to occur at Vaseys Paradise, Arizona. The management of ambersnails at Vaseys Paradise, Arizona, is balanced with ecosystem-wide management of other natural resources in the Grand Canyon. Data used to resolve the taxonomic status of ambersnails include anatomical variation, morphological variation, and genetic variation of mitochondrial and nuclear DNA. Much data were collected for anatomical, morphological, and genetic markers for ambersnails from 12 populations across Arizona and Utah.

\section{Methods}

A combination of morphological and molecular methods was used in this study, starting with careful sampling of all 12 known ambersnail populations in Arizona and Utah. The same samples were used for all data collection methods; a small part of each sample was used for mitochondrial and nuclear genetic analyses and the remainder was used for anatomical and morphological analyses.

\section{Specimen Collection}

We restricted the sample collections to 12 southwestern ambersnail populations that were selected based on their historical or conservation importance, previous taxonomic designations applied to specimens obtained from these locations, or because the population in question recently has been discovered and has never been the subject of genetic or morphological analyses. Samples were collected from 12 locations in Arizona and Utah (table 1). Sample collections were also attempted at one location in Nevada (Maggie Creek), but several trips there did not reveal any snails. Each of the 12 sampling locations generated a "batch" of samples: Batches 1-12, corresponding to each of 12 sampling locations. Between 20 and 25 samples were collected from each location except Batch 1 (with 14 samples) and Batch 12 (with 16 samples). Because samples from Batch 11 were not mature individuals, Batch 11 sample specimens were not included in the anatomical analyses. Four additional batches were sampled (test batches A, B, C, and D), which were used exclusively 
Table 1. Site name and locality description of ambersnail populations in Arizona and Utah sampled for the anatomical and genetic analyses described in this study.

[Information is provided about the taxonomic designations of the limited numbers of snails previously identified from the 12 sampling locations. Abbreviations: km, kilometer; mi, mile]

\begin{tabular}{|c|c|c|c|c|}
\hline $\begin{array}{l}\text { Batch } \\
\text { No. }\end{array}$ & Site name & State & Locality & Previous taxonomic designation \\
\hline 1 & Sonoita Creek & Arizona & Near Fresno Canyon & Catinella \\
\hline 3 & Indian Garden & Arizona & $\begin{array}{l}\text { Indian Garden Campground in Grand Canyon } \\
\text { National Park }\end{array}$ & Oxyloma haydeni haydeni \\
\hline 5 & The Greens ${ }^{2}$ & Utah & $\begin{array}{l}\text { Best Friends Ranch along Highway } 89 \text { north of } \\
\text { Kanab, Utah }\end{array}$ & Oxyloma retusum, O. haydeni haydeni \\
\hline 6 & Glendale Highway & Utah & $\begin{array}{l}\text { KOA Campground } 3 \text { km north of Glendale on } \\
\text { Highway } 89\end{array}$ & Oxyloma retusum \\
\hline 9 & Three Lakes & Utah & 6 km north of Kanab, Utah, along Kanab Creek & Oxyloma haydeni kanabense \\
\hline 10 & Pass Creek & Utah & $\begin{array}{l}\text { Along Highway 143, } 0.5 \text { mi north of Pass Creek Road, } \\
\text { north of Panguitch Lake }\end{array}$ & Oxyloma? (undescribed species) \\
\hline 11 & Panguitch Creek & Utah & Pole Hollow Bridge & Oxyloma retusum \\
\hline 12 & Escalante River & Utah & Wet meadow upstream & Oxyloma? \\
\hline
\end{tabular}

${ }^{1}$ River Mile (RM) is used to describe distances along the Colorado River in the study area. The use of the river mile has historical precedent and provides a reproducible method for describing location. Lees Ferry is considered the reference point, RM 0, with mileage measured for both upstream and downstream locations. Locations upstream of Lees Ferry in the Glen Canyon National Recreation Area are assigned negative river-mile designations. "R” in “31.5R” refers to the right bank of the river viewed in the downstream direction.

${ }^{2}$ Although considered to be the Kanab ambersnail (Oxyloma haydeni kanabense) type locality, no Kanab ambersnails have been observed there since 1991 (Meretsky and others, 2002).

for genetic testing. Samples from Batches 1-10 and 12 are considered voucher specimens and are curated by Barry Roth for placement into a museum. DNA sequences linked to these voucher specimens have been deposited in GenBank ${ }^{\circledR}$ (appendix A) with the exceptions of nuclear 356 sequences, which were too short to deposit in GenBank ${ }^{\circledR}$, and nuclear internal transcribed spacer (ITS) sequences, which had a high likelihood of homoplasy (convergent evolution). Because multiple copies of the ITS sequence were located throughout the genome of each individual, we were uncertain if the comparable versions of the ITS gene among individuals were being analyzed. Instead, the sequences for 356 and ITS are included in appendixes B and $\underline{C}$, respectively.

Sterile sample vials and fresh preservative solutions were used for all collections to prevent possible contamination. All snails were handled with clean forceps. Live specimens were drowned in a closed container of water and transferred by stages to 70 percent ethanol (EtOH). Following the initial drowning, a small piece of foot tissue from each animal was preserved separately in 95 percent EtOH for use in genetic analyses. Each specimen was labeled with a unique identification number that was linked to a database of information indicating the specimen's population affiliation, collection date, and other relevant information. This information was duplicated in a field journal as backup. When satellite coverage was available, a Garmin ${ }^{\mathrm{TM}}$ GPS unit was used to record locality information: a minimum of 180 waypoints were averaged and saved to improve accuracy of site location. Representative digital photographs were made of each locality for later reference. Localities and their descriptions are provided in figure 1 and table 1 , respectively, with the figure including only Oxyloma localities and the table including descriptions of Oxyloma and Catinella localities. 


\section{Shell Morphology}

The counts, dimensions, and calculated values recorded from shells in the samples were selected to provide a dataset that effectively expresses size and shape variability in the system of shell characters. The succineid shell is simple for a gastropod shell; there is little surface sculpture (none considered significant during this investigation) and there is no departure from the initial coiling trajectory as an individual nears adulthood, unlike in some other land-snail families. For this reason, relatively few parameters were adequate to characterize the shells in the samples at an acceptable level of generality. More measurements would introduce the risk of tracking individual, secular variation that would amount to noise in the phylogenetic system.

Shells were released from the soft parts (held with fine forceps) by gentle, twisting pressure. Where necessary, algal film on the surface was removed by brief immersion in an ultrasonic pen cleaner (Koh-i-noor $\left.{ }^{\circledR}\right)$. Shells were photographed digitally in standard apertural view with both shell axis and maximum width of the aperture in the plane of the page. The images were printed at a standard enlargement (8.5 times). On the resulting prints, two lines were drawn tangent to the right and left sides of the first whorl and the body whorl, respectively, delineating the apical angle of the shell. The coiling axis was delineated by a line from the vertex of this angle through the columellar side of the aperture.

The following measurements and counts were recorded for each shell image (SI):

Apical angle (APA) - angle between two lines tangent to the right and left sides of the first whorl and the body whorl, respectively, measured with a protractor.

SI (shell image) length (IL) - distance between the apex of the shell and the lowest extent of the aperture, measured parallel to the axis.

SI maximum diameter (ID) — greatest width of the shell measured normal to the axis.

SI height of maximum diameter (IMD)—distance from the lowest extent of the aperture to the point of greatest diameter, measured parallel to the axis.

SI aperture length (IAL) - distance from the junction of the posterior lip of the aperture with the preceding whorl to the lowest extent of the aperture, measured parallel to the axis.

SI aperture width (IAW) - maximum width of the aperture measured perpendicular to the axis.
Number of whorls (WN) — counted by the method of Verduin (1982).

Width of whorl 1 (W1) — distance from axis to insertion of first whorl upon suture of second whorl, on apertural (anatomically, right) side of shell, measured perpendicular to the axis.

Width of whorl 2 (W2) - distance from insertion of first whorl to insertion of second whorl upon suture of third whorl, on apertural side of shell, measured perpendicular to the axis.

Width of whorl 3 (W3) - distance from insertion of second whorl to insertion of third whorl upon suture of fourth whorl, on apertural side of shell, measured perpendicular to the axis.

Width of whorl 4 (W4) — distance from insertion of third whorl to maximum extent of fourth whorl, on apertural side of shell, measured perpendicular to the axis.

These SI measurements were divided by 8.5 to convert them to the following shell dimensions: Shell length (SL), shell maximum diameter (SD), height of maximum diameter (SMD), shell aperture length (SAL), and shell aperture width (SAW). Shell dimensions, rather than SI measurements, were used in statistical analysis.

From these dimensions, the following sum and ratios were calculated, generating some of the traditional characters used in the description of gastropod shells and used in this study as characters for phylogenetic analysis:

Shell size (SS) — shell length plus shell maximum diameter (SL + SD); for use of this sum as a measure of overall size, see Gould (1969) and Galler and Gould (1979).

Relative height (SRH)—shell length/shell maximum diameter (SL/SD).

Relative aperture height (SRA)—shell aperture length/ shell length (SAL/SL).

Aperture asymmetry (APY) — height of maximum diameter/shell aperture length (SMD/SAL). This character expresses the departure of the shape of the aperture from, approximately, an ellipse. A value of 0.50 represents a figure with its widest extent at its midpoint, like an ellipse. A low value produces what is traditionally described as an "effuse" aperture, which is wide near the anterior end. 
Shell coiling parameters (Raup, 1966; also see Kohn and Riggs, 1975; Lindberg, 1985) were calculated from unconverted image measurements:

S (“apertural shape”) = SI aperture length/SI aperture width.

$\mathrm{W}$ (“whorl expansion rate”) $=(\mathrm{W} 1 / \mathrm{W} 2+\mathrm{W} 2 / \mathrm{W} 3+$ $\mathrm{W} 3 / \mathrm{W} 4) /(\mathrm{WN}-1)$

$\mathrm{T}$ ("translation") $=\mathrm{Y} / \mathrm{R}$, where $\mathrm{Y}$ is the distance of the center of the generating curve from the apex of the shell, measured parallel to the axis (calculated herein as shell image length minus one-half of SI aperture length), and $\mathrm{R}$ is the distance of the center of the generating curve from the axis (calculated herein as one-half the SI aperture width).

A fourth coiling parameter, D (Raup, 1966), representing the distance of the generating curve from the axis, was observed, from inspection of the shells, to equal zero in all cases. No specimens had an umbilicus, the void created down the center of a shell when the generating curve migrates away from the coiling axis. This parameter was not considered further in the study.

The data on samples identified as Oxyloma (that is, all but the sample from Sonoita Creek, Arizona, which is a sample of Catinella included in the study to serve as an outgroup in phylyogenetic analysis) were examined by principal components analysis and discriminant analysis with the software SYSTAT $12{ }^{\circledR}$ for Windows. Principal components analysis was used to examine the sources of variation among the entered variables and to generate a reduced set of factors ("components") to express that variation in coherent terms. Discriminant analysis was used to assess the performance of individual variables for discriminating among samples. Three sets of variables were subjected to discriminant analysis, representing three different approaches of traditional taxonomy toward recognizing discrete taxonomic units.

The holotype of Oxyloma haydeni kanabensis Pilsbry, 1948 (Academy of Natural Sciences of Philadelphia specimen 103166) was submitted to discriminant analysis as an unclassified case, to determine to which of the established groups it would be assigned. Previous studies using discriminant analysis to assign type specimens to subsequently defined or recognized categories include those of Shaklee and Tamaru (1981) and Lindberg (1985).

\section{Soft Tissue Anatomy}

Specimens were dissected on paraffin in 70 percent EtOH following standard methods for this type of anatomical examination (for example, Patterson, 1973; Hoagland and Davis, 1987). Soft parts were held with fine forceps and released from the shells by gentle, twisting pressure. Color and patterning of the mantle and head-foot were recorded. The body cavity was opened by dorsal or right-lateral incision and by paring back the mantle over the lung. Organs of the body cavity were observed in place. Anatomical features examined included the character and size of the hermaphrodite duct, albumen gland, prostate gland, spermatheca and its duct, vas deferens, epiphallus, penis, penial appendix (where present), vagina, and free oviduct.

\section{DNA Isolation}

We extracted DNA from 292 snail tissue samples (foot pieces and whole soft bodies) from 12 populations and 4 batches of samples used only for testing marker variability. We used phenol-chloroform and standard silica-based methods of DNA extraction and purification, and DNA was quantified using PicoGreen ${ }^{\circledR}$ and measured in a fluorometer.

\section{Genetic Analyses}

Several types of molecular genetic markers were used to analyze the ambersnail specimens. In total these markers represented a mixture of coding regions (or genes) and noncoding regions (including repetitive and non-repetitive DNA).

\section{Mitochondrial DNA}

Mitochondrial DNA evolves more rapidly than nuclear DNA and is maternally inherited. Two genes were selected within the mitochondrial genome based on their rate of evolution and widespread use in other mollusk studies.

\section{Data Generation}

Two mitochondrial genes were sequenced for use in the analyses. First, we used the universal molluscan primers HCO12198 and LCO1490 described in Folmer and others (1994) to amplify about $600 \mathrm{bp}$ of the mitochondrial cytochrome oxidase subunit I gene (COI). Likewise, we used the universal primers of Merritt and others (1998) to amplify about $410 \mathrm{bp}$ of the mitochondrial cytochrome $b$ gene (cyt $b$ ). Fragments were sequenced bi-directionally on an ABI3730 DNA sequencer using standard methods. Sequence chromatograms were aligned and edited using the Seqman and Megalign software packages (Lasergene ${ }^{\circledR}$, Inc.). After editing, sequences were trimmed to $510 \mathrm{bp}$ for the COI gene and to $366 \mathrm{bp}$ for the cyt $b$ gene. In total, 176 individuals were sequenced for the COI gene and 183 individuals were sequenced for the cyt $b$ gene. Specific information on sample sizes from each location is provided in table 2. Five members of the Catinella outgroup population amplified and we also downloaded three mtDNA COI sequences from GenBank ${ }^{\circledR}$ to use as outgroups for this study, from Catinella baldwini (GenBank ${ }^{\circledR}$ accession number AY148571.1), and Neosuccinea kofui (GenBank ${ }^{\circledR}$ accession number AY150085.1).

Additionally, we sequenced the partial COI gene for Succinea concordialis. 
Table 2. Number of ambersnail samples per population in Arizona and Utah, sequenced for two mitochondrial DNA (mtDNA) loci, the concatenated mtDNA loci, the four nuclear DNA loci, and the Amplified Fragment Length Polymorphism (AFLP) analyses.

[Samples from the introduced Elves Chasm population were not sequenced for mtDNA loci nor included in the AFLP analyses. C OI: cytochrome oxidase subunit I gene. cyt $\boldsymbol{b}$ : cytochrome $b$ gene. mtconcat: mitochondrial genes concatenated. S7: ribosomal gene introns S7-1 and S7-2. ITS: ribosomal DNA first and second internal transcribed spacer. 356: random ambersnail nuclear clone 356. 458: random ambersnail nuclear clone 458. AFL P: Amplified Fragment Length Polymorphism. -, no data]

\begin{tabular}{|c|c|c|c|c|c|c|c|c|}
\hline \multirow{2}{*}{ Locality } & \multicolumn{8}{|c|}{ DNA genes or regions } \\
\hline & $\mathrm{COI}$ & cyt $b$ & mtconcat & S7 & ITS & 356 & 458 & AFLP \\
\hline Minus 9-Mile Spring-Lees Ferry (LF) & 19 & 20 & 16 & 22 & 20 & 12 & 10 & 23 \\
\hline Indian Garden (IG) & 23 & 20 & 19 & 21 & 7 & 0 & 9 & 25 \\
\hline Vaseys Paradise (VP) & 13 & 16 & 13 & 17 & 17 & 13 & 16 & 18 \\
\hline The Greens (Greens) & 19 & 21 & 16 & 24 & 1 & 24 & 21 & 24 \\
\hline Glendale Highway (GHwy) & 17 & 21 & 15 & 22 & 20 & 14 & 9 & 25 \\
\hline Center Creek (CCrk) & 16 & 20 & 16 & 18 & 3 & 18 & 4 & 19 \\
\hline Sevier River (SR) & 5 & 11 & 4 & 17 & 0 & 10 & 9 & 19 \\
\hline Three Lakes (3L) & 13 & 4 & 2 & 20 & 16 & 16 & 0 & 20 \\
\hline Pass Creek (PasCrk) & 9 & 14 & 8 & 15 & 6 & 3 & 2 & 17 \\
\hline Panguitch Creek (PanCrk) & 0 & 2 & 0 & 20 & 10 & 5 & 12 & 0 \\
\hline Escalante River (ER) & 7 & 14 & 7 & 16 & 16 & 16 & 9 & 16 \\
\hline Elves Chasm (ECh) & - & - & - & 10 & 10 & 7 & 8 & 0 \\
\hline Total & 141 & 163 & 116 & 222 & 126 & 138 & 109 & 206 \\
\hline
\end{tabular}

\section{Nuclear DNA}

Nuclear DNA has a broad variety of marker types from coding, non-coding, single copy, multilocus, and repetitive regions - each with different evolutionary rates. Our selection of nuclear markers included all these categories and spanned a sampling of the entire nuclear genome.

\section{Single Copy}

To identify nuclear loci for Polymerase Chain Reaction (PCR) amplification, we applied two strategies. First, we tested published primers, which had previously been used in other studies, and, second, we created a genomic library.

\section{Markers from Other Studies}

We designed primers and optimized PCR amplification conditions for seven different nuclear loci: an intron of the aminopeptidase N gene (AP54; Sokolova and Boulding, 2004), ribosomal DNA first and second internal transcribed spacer (ITS-1 and ITS-2; Armbruster and others, 2000), large subunit 28S rDNA (LSU; Teshima and others, 2003), 6-phosphogluconate dehydrogenase (PGD; Lee and Foighil, 2002), and S7 ribosomal gene introns (S7-1 and S7-2; Chow and Hazama, 1998). These loci had been used in genetic studies in different animal groups ranging from gastropods to fish. We designed new primers for some loci (AP54, ITS and S7). Next, we sequenced 10 different DNA fragments from 6 of the initial 7 published loci for one snail from Vaseys Paradise ("Kanab ambersnail”), and one snail from Indian Garden ("Niobrara ambersnail”). We were able to align sequences in 8 of the 10 fragments. An 800-bp fragment of S7-1 (S7) and a 400-bp fragment of ITS-1 (ITS) showed much variation between the Vaseys Paradise and the Indian Garden specimens. The other eight fragments showed no variation between the specimens of the two populations and, therefore, were determined to be uninformative for this study.

\section{Genomic Library}

We constructed a non-enriched genomic library to develop a set of random single nucleotide polymorphism (SNP) markers for Oxyloma. We amplified 250 positive clones and sequenced 150 clones for a total of about 65 kilo base pairs (kbp). We designed primers using OLIGO 6.6 (Molecular Biology Insights, Inc.) and PRIMER3 (Rozen and Skaletzky, 2000), and optimized PCR reactions to amplify and sequence snail test panels from different populations to assess marker variability and informativeness. Two cloned sequence fragments, 458 and 356, showed much variation and were suitable for this study. However, there were many variable sites per clone, instead of single sites typical for SNPs. We, therefore, performed genotyping by sequencing the complete fragment for all individuals. For primer sequences and annealing temperatures, see table 3 . 
Table 3. Polymerase Chain Reaction (PCR) primer sequences used for PCR amplification and the appropriate PCR annealing temperatures for each of the five nuclear loci used in this study of Oxyloma popul ations.

[Samples from the introduced Elves Chasm population were not sequenced for mtDNA loci nor included in the AFLP analyses. Primer sequence $\left(\mathbf{5}^{\prime} \rightarrow \mathbf{3}^{\prime}\right)$ : 5 prime to 3 prime. A bbreviations: $\mathrm{T}_{\mathrm{a}}$, annealing temperature; ${ }^{\circ} \mathrm{C}$, degrees Celsius; F, forward; R, reverse; S7, ribosomal gene introns S7-1 and S7-2; ITS, ribosomal DNA first and second internal transcribed spacer; 356, random ambersnail nuclear clone 356; 458, random ambersnail nuclear clone 458; KS6511, simple tandem repeat (STR) locus KS6511]

\begin{tabular}{llc}
\hline \multicolumn{1}{c}{ Locus } & \multicolumn{1}{c}{ Primer sequence $\left(\mathbf{5}^{\prime} \rightarrow \mathbf{3}^{\prime}\right)$} & $\mathbf{T}_{\mathbf{a}}\left({ }^{\circ} \mathbf{C}\right)$ \\
\hline S7 & F: CTGACTTTGTTCTGTTTCTGT & 50 \\
& R: TCTATCTCCTGGTTCATTGAT & \\
ITS & F: TGCGGAAGGATCATTATCGT & 56 \\
& R: CGCTTAAAGTTGTCAGATGA & \\
356 & F: TGATCGGCTAATGCTCTTGG & 58 \\
& R: AAAACAAACATTAAACACCCAGTAGA & \\
458 & F: TAAAATATGGTTTGGTTTCGTT & 51 \\
\multirow{2}{*}{ KS6511 } & R: CGTTGGTGTTGGTCAGCA & \\
& F: TATTGGCACGCTGCTTAATG & 53 \\
\hline
\end{tabular}

DNA fragments were sequenced bidirectionally on an ABI3730XL DNA Analyzer. Sequences were assembled and aligned with SEQUENCHER 4.2.2. (Gene Codes Corporation, 2010) and edited using MacClade version 4.03 (Maddison and Maddison, 2001). As analysis software treats indels as missing data, we recoded indels of the same length and at the same position as an additional binary nucleotide site. If we encountered indels of different lengths at the same position, we treated each indel defined by a specific number of nucleotides as a separate binary character. If polymorphism was present within one individual, this could be detected from direct sequencing using our DNA sequencing methodology, allowing both alleles to be scored for an individual. After sequence alignment, the program PHASE 2.1 (Stephens and others, 2001; Stephens and Scheet, 2005), which uses a Bayesian algorithm, was used for haplotype reconstruction of autosomal loci (to set phase for each allele and to determine haplotypes in polymorphic individuals).

\section{Data Analyses-Mitochondrial DNA and Nuclear Single Copy DNA}

We performed an analysis of molecular variance (AMOVA) (Excoffier and others, 1992), using the program package ARLEQUIN 3.1 (Excoffier and others, 2006), and likewise calculated pairwise $\mathrm{F}_{\text {st }}$ values between all analyzed populations. We graphically visualized pairwise $\mathrm{F}_{\mathrm{st}}$ values between populations by applying multidimensional scaling (MDS) using NTSSpc 2.0 (Applied Biostatistics Inc.).

To test for isolation by distance, we used NTSSpc 2.0 (Applied Biostatistics Inc.) to perform Mantel tests (to estimate the correlation between geographical distances and genetic distances between populations) (Slatkin and Maddison, 1990). The analysis was performed separately for each gene.

To test for neutrality and demographic stability, we computed Tajima's D (Tajima, 1989), Fu’s F (Fu, 1997), and mismatch distribution (Rogers and Harpending, 1992) using ARLEQUIN 3.1. Values for $\mathrm{R}_{2}$ (Ramos-Onsins and Rozas, 2002) were calculated with DNASP 4.10 (Rozas and others, 2003).

Median joining haplotype networks were constructed with the program NETWORK 4.2.0.1 of Fluxus Technology Ltd. (Bandelt and others, 1999). For phylogenetic analyses, we used the software package PAUP 4.0b10 (Swofford, 2002). We performed neighbor joining (NJ) analyses as well as maximum parsimony (MP) analyses with heuristic searches, tree bisection and reconnection (TBR), and branch swapping and bootstrapping (100 replicates). Additionally, we performed Bayesian analyses (MB) using the program MrBayes version 3.1 (Ronquist and Huelsenbeck, 2003). We calculated the best fitting model of nucleotide substitution by using MODELTEST 3.7 (Posada and Crandall, 1998). The following models were found: COI TVM+I+G, cyt $b$ $\mathrm{HKY}+\mathrm{I}+\mathrm{G}$, concatenated mitochondrial loci TVM+I+G, 356 K81uf+I, 458 TVM+I, ITS GTR+G, S7 HKY+I, and concatenated autosomal loci TVM+I+G. MrBayes ran with 10,000,000 generations in four Markov Chain Monte Carlo chains. An appropriate burnin was selected by assessing the MrBayes trace files with the program TRACER 1.3 (Rambaut and Drummond, 2005). The number of generations at burnin was 4,000 in all analyses. Because no outgroup data were available for many of the analyses, some of the phylogenetic analyses were performed without an outgroup. Those phylogenetic trees, therefore, are unrooted. However, a single outgroup rooted tree was performed using COI sequences from GenBank ${ }^{\circledR}$ from the outgroups Catinella, Succinea, and Neosuccinea. These sequences were aligned with mtDNA concatenated sequences from this study, and a maximum likelihood phylogenetic analysis was performed with RAxML 7.0.3 (Stamatakis, 2006). RAxML parameters were set to GTRGAMMA substitution model, 1,000 bootstrap iterations, and Catinella was designated as the outgroup.

\section{Microsatellite (Single Locus)}

Because of the repetitive sequences at microsatellite loci, these markers have rapid evolutionary rates. As a result, microsatellites are a high-resolution molecular genetic tool suitable for subspecies-level taxonomic analyses. 


\section{Genomic Library}

For microsatellite analyses, we constructed a Kanab ambersnail genomic library, enriched for microsatellite motifs following the protocol by Hamilton and others (1999) using the Invitrogen TOPO ${ }^{\circledR}$ TA Cloning ${ }^{\circledR}$ Kit. We developed multiple different primer pairs that were designed to amplify nuclear genomic regions containing short tandem repeats within the genus Oxyloma. These microsatellite primers were designed following analyses of about 200 microsatellite enriched clones of restriction fragments from the Oxyloma genome. Unfortunately, almost all subsequent attempts at implementing these microsatlellite primers in the full dataset were uninformative. Microsatellite primers frequently could not be amplified across all populations from the dataset, and often also produced multiple peaks that were inconsistent with amplification of a single Mendelian genetic locus. Only one microsatellite locus, KS6511, successfully amplified across all populations using forward and reverse primers, which are listed in table 3. Although we have included data from microsatellite KS6511 in this study, given our goal of characterizing nuclear variation within the genus Oxyloma, we subsequently implemented the AFLP procedure to generate "highly variable" multilocus nuclear genetic data for our full dataset, as described in section AFLP (Multilocus) of the Methods section.

\section{PCR Conditions}

PCR conditions for the one microsatellite locus that amplified, KS6511, were 10 ng DNA in 10 millimolar (mM) Tris $\mathrm{pH}$ 8.3, $50 \mathrm{mM}$ potassium chloride $(\mathrm{KCl}), 2.5 \mathrm{mM}$ magnesium chloride ( $\mathrm{MgCl}_{2}$ ), $1 \mathrm{mM}$ dNTPs, 0.5 Units Platinum Taq (Invitrogen), 2 picomolar (pM) forward primer (with M13 5' extension TGTAAAACGACGGCCAGT), 4 pM reverse primer (with PIGtail 5' extension GTTTCTT), 4 pM M13 primer with fluorescent label (FAM6) in a final volume of $10 \mu \mathrm{L}$. The cycling conditions were: initial denaturation at $94^{\circ} \mathrm{C}$ for 3 minutes, followed by 20 cycles of denaturation at $94^{\circ} \mathrm{C}$ for 30 seconds, annealing at $55^{\circ} \mathrm{C}$ for 30 seconds, and extension at $72^{\circ} \mathrm{C}$ for 30 seconds; then 15 cycles of denaturation at $94^{\circ} \mathrm{C}$ for 30 seconds, annealing at $53^{\circ} \mathrm{C}$ for 30 seconds, and extension at $72^{\circ} \mathrm{C}$ for 30 seconds; followed by a final extension at $72^{\circ} \mathrm{C}$ for 10 minutes.

\section{AFLP (Multilocus)}

AFLPs have a moderate mutation rate, but tend to be informative because many loci are typed at one time. Multilocus markers, such as AFLPs, have the advantage of being useful markers when not much information is available about the study organism's genome.

\section{Data Generation}

We used the AFLP procedure of Vos and others (1995) to generate nuclear genetic markers for 206 individuals (see table 2 for information about sample sizes from each population). AFLP reactions were performed using the methods described in Miller and others (2006). In total, the second selective PCR reaction (the stage at which multilocus AFLP fingerprints were generated) was performed using two different sets of primers: Eco-ACG/Mse-ACG and Eco-ACG/ Mse-ATC. AFLP fragments produced in the second selective PCR reaction were resolved with an ABI 3100 automated DNA sequencer (Applied Biosystems, Inc.) using the manufacturer's protocols and analyzed using the GeneScan ${ }^{\circledR}$ Analysis software package (Life Technologies Corp., 2013). After analysis, we viewed sample files and scored the presence or absence of individual AFLP markers using Genographer 1.6 (Benham, 2001). In total, data from 69 polymorphic loci were recorded from the two primer combinations examined.

\section{Data Analyses}

AFLP data initially were analyzed using the Unweighted Pair Group Method with Arithmetic mean (UPGMA) clustering algorithm implemented in the program NT-SYSpc v2.10 (Exeter Software, Inc.). The Dice coefficient option was used when calculating pairwise similarity coefficients among all analyzed individuals. To examine more thoroughly the population structure among southwestern Oxyloma populations, we used the Bayesian clustering algorithm of Pritchard and others (2000) as implemented in the software package STRUCTURE 2.2 (Pritchard and others, 2000). This analysis was used to (1) identify the most likely number of genetic clusters or populations (K) that exist, and (2) estimate the proportion of each analyzed individual's genome that was derived from each of the K clusters. Analyses were performed using 5 replicates for each value of $\mathrm{K}$, where $\mathrm{K}$ ranged from 4 to 13 . For each analysis replicate, 5,000 burnin steps were used followed by an additional 20,000 Markov chain Monte Carlo sweeps. The "admixture model" and "correlated allele frequencies” options were used when performing each analysis. When analyses were completed, likelihood scores from each replicate value of $\mathrm{K}$ were evaluated using the guidelines in Pritchard and others (2000) to infer the true number of distinct genetic clusters. A graphical summary of STRUCTURE analyses was subsequently generated using the program Distruct (Rosenberg, 2004). 


\section{Results}

Results are summarized below on all aspects of this study. The organismal aspects are presented with specimen collection, anatomical analyses, and morphological analyses, followed by the molecular aspects with the DNA analyses.

\section{Specimen Collection}

Based on observations from our field collections team prior to and during this study, the number of species present at each of the sampling locations was

- Vaseys Paradise-in addition to one species of Oxyloma, there also were three species of Catinella at the location, albeit much less common than the Oxyloma that dominated that location;

- Three Lakes—a single Succineid snail shell was found at the location during a visit in 1996, but Oxyloma was the dominant land snail at the location;

- Elves Chasm-during 2008-10, only a few Catinella were detected in the area where Oxyloma were released;

- Lees Ferry-Catinella occurred at the location, but prefers slightly drier habitat than Oxyloma (similar to Vaseys Paradise with these Succineids);

- Indian Garden-no Catinella reported in the areas where we found Oxyloma; and

- other locations in Utah-no Catinella observed at the specimen collection locations for this study, but that was expected because our focus areas were those believed to have the best Oxyloma habitat.

At the time of our collections for this study, our lead field biologist had about 9-10 years of experience in sampling for and conducting field identifications of Succineid snails in the Grand Canyon region. He has the expertise and ability to distinguish the difference in shells and appearance of Oxyloma and Catinella. Other members of the field team likewise had the same level of experience in distinguishing between the two genera while in the field. Although the differences in shells and appearance between the two genera are subtle, and difficult for novices to recognize, we are highly confident that we properly distinguished the difference between the two genera at locations that were visited and used in this study.

\section{Shell Morphology}

Sample ranges, means, and standard deviations of the entered variables are presented in table 4. The correlation matrix for the ungrouped data indicated that a factor-analytic model was marginally applicable. Fifty-two (66 percent) of 78 pairs of variables have correlation coefficients of less than 0.3 (table 5). The strongest correlations were among the raw measurements of size (SL, SD, SAL, SAW, and SMD).

\section{Principal Components Analysis}

Thirteen principal components were computed. The first four components account for 89.572 percent (44.570, $26.226,10.278$, and 8.498 percent, respectively) of the total variance. Table 6 shows loadings of the entered variables. The first principal component, shell size (SS), primarily expressed size. A high score for this component indicated a large shell with a large aperture (although not necessarily an aperture large in relation to overall shell size). Apical angle (APA), apertural asymmetry (APY), and whorl expansion rate (W) load negatively on component 1 , although not with high values. Translation (T, negatively), APA, and relative height (SRH, negatively) load strongly on component 2. A high score on this component indicated a shell with an obtuse apex and a relatively broad shell, in which the center of the generating curve translated slowly along the axis of coiling. Relative aperture height also loads strongly on component 2 , indicating a shell with a relatively short spire posterior to the aperture. Component 3 largely was an expression of the effuseness of the aperture, with APY and height of maximum diameter (SMD) loading strongly; a high score on this component indicated a shell with an effuse, asymmetric aperture. Apertural shape (S) and, to a lesser extent, relative aperture height (SRA), and APY (negatively) load strongly on component 4. A high score on this component indicated a shell with a proportionally narrow aperture that was symmetrical and long relative to shell length.

A plot of individual Oxyloma specimen scores on principal components 2 (the "narrow shell" component) and 3 (the "effuse aperture" component) (fig. 2) showed extensive overlap among all samples ("batches"). As shown by individual sample plots (fig. 3), shells from Three Lakes and The Greens tended to have asymmetrical, effuse apertures (scoring high on principal component 3). Indian Garden shells tended to be relatively broad, with obtuse apices (generally scoring high on the principal component 2). Shells from Vaseys Paradise tended to be "middle of the pack" with respect to effuseness, and moderate to obtuse and broad with respect to shell shape.

Plots of individual Oxyloma specimen scores on principal components 3 and 4 (the "narrow, symmetrical aperture" component) (fig. 4) showed less difference among the point scatters. Some samples, such as Glendale Highway and Lees Ferry, varied widely in their scores on principal component 4. 


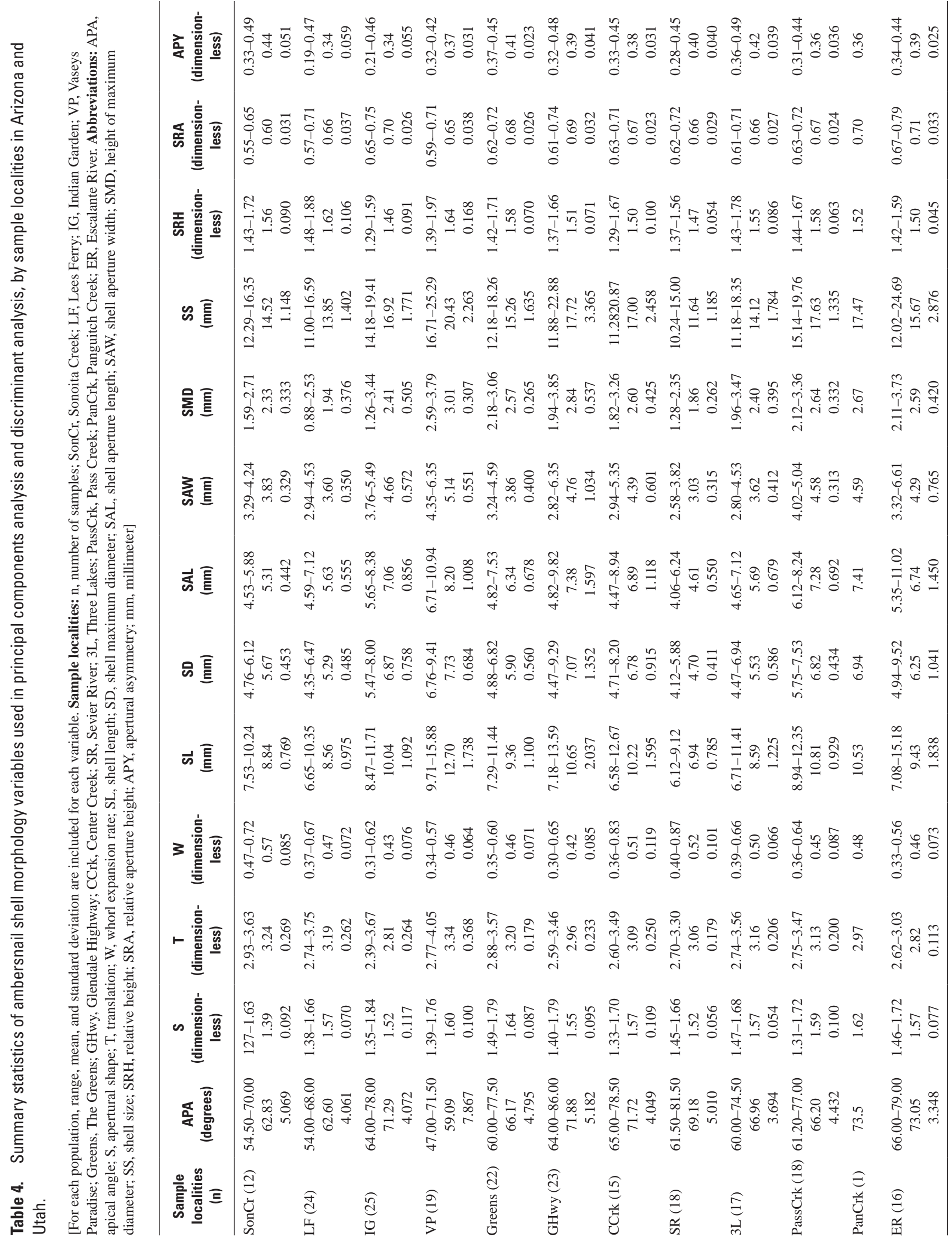




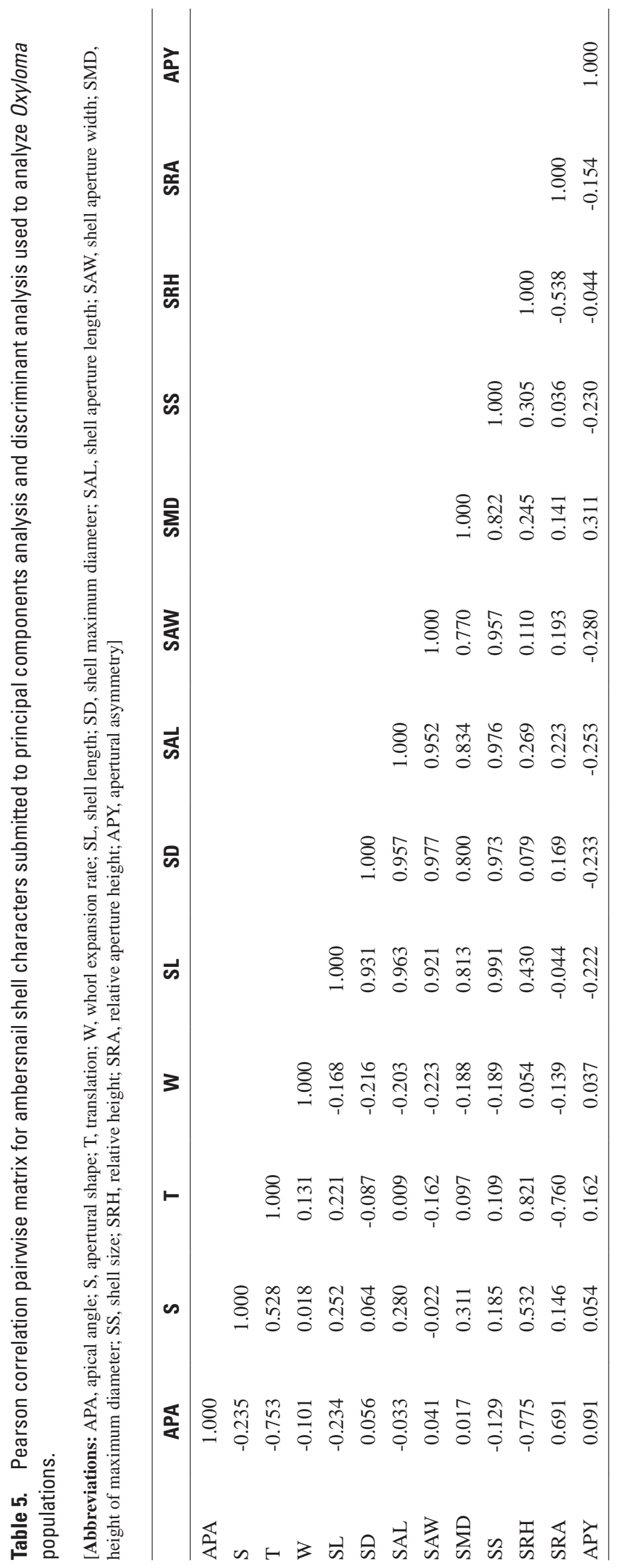


Table 6. Component loadings of variables measured in Oxyloma populations, eigenvalues, and percent of total variance explained by the first four components in principal components analysis of shells of Oxyloma.

[A bbreviations: SS, shell size; SL, shell length; SAL, shell aperture length; SD, shell maximum diameter; SAW, shell aperture width; SMD, height of maximum diameter; T, translation; APA, apical angle; SRH, relative height; SRA, relative aperture height; APY, apertural asymmetry; S, apertural shape; $\mathrm{W}$, whorl expansion rate]

\begin{tabular}{|c|c|c|c|c|}
\hline Variahle & Component & Component & Component & Component \\
\hline Varıable & 1 & 2 & 3 & 4 \\
\hline SS & 0.992 & 0.016 & -0.081 & -0.057 \\
\hline SL & 0.989 & -0.109 & -0.076 & -0.031 \\
\hline SAL & 0.988 & 0.111 & 0.002 & 0.095 \\
\hline SD & 0.954 & 0.226 & -0.086 & -0.099 \\
\hline SAW & 0.943 & 0.254 & -0.163 & -0.107 \\
\hline SMD & 0.857 & 0.036 & 0.457 & -0.203 \\
\hline $\mathrm{T}$ & 0.121 & -0.958 & 0.105 & 0.002 \\
\hline APA & -0.131 & 0.865 & 0.275 & 0.028 \\
\hline SRH & 0.349 & -0.859 & -0.004 & 0.165 \\
\hline SRA & 0.087 & 0.788 & 0.276 & 0.502 \\
\hline APY & -0.195 & -0.130 & 0.797 & -0.545 \\
\hline $\mathrm{S}$ & 0.271 & -0.427 & 0.530 & 0.665 \\
\hline W & -0.228 & -0.207 & -0.049 & 0.094 \\
\hline Eigenvalue & 5.794 & 3.409 & 1.336 & 1.105 \\
\hline $\begin{array}{l}\text { Percent of variance } \\
\text { explained }\end{array}$ & 44.570 & 26.226 & 10.278 & 8.498 \\
\hline
\end{tabular}
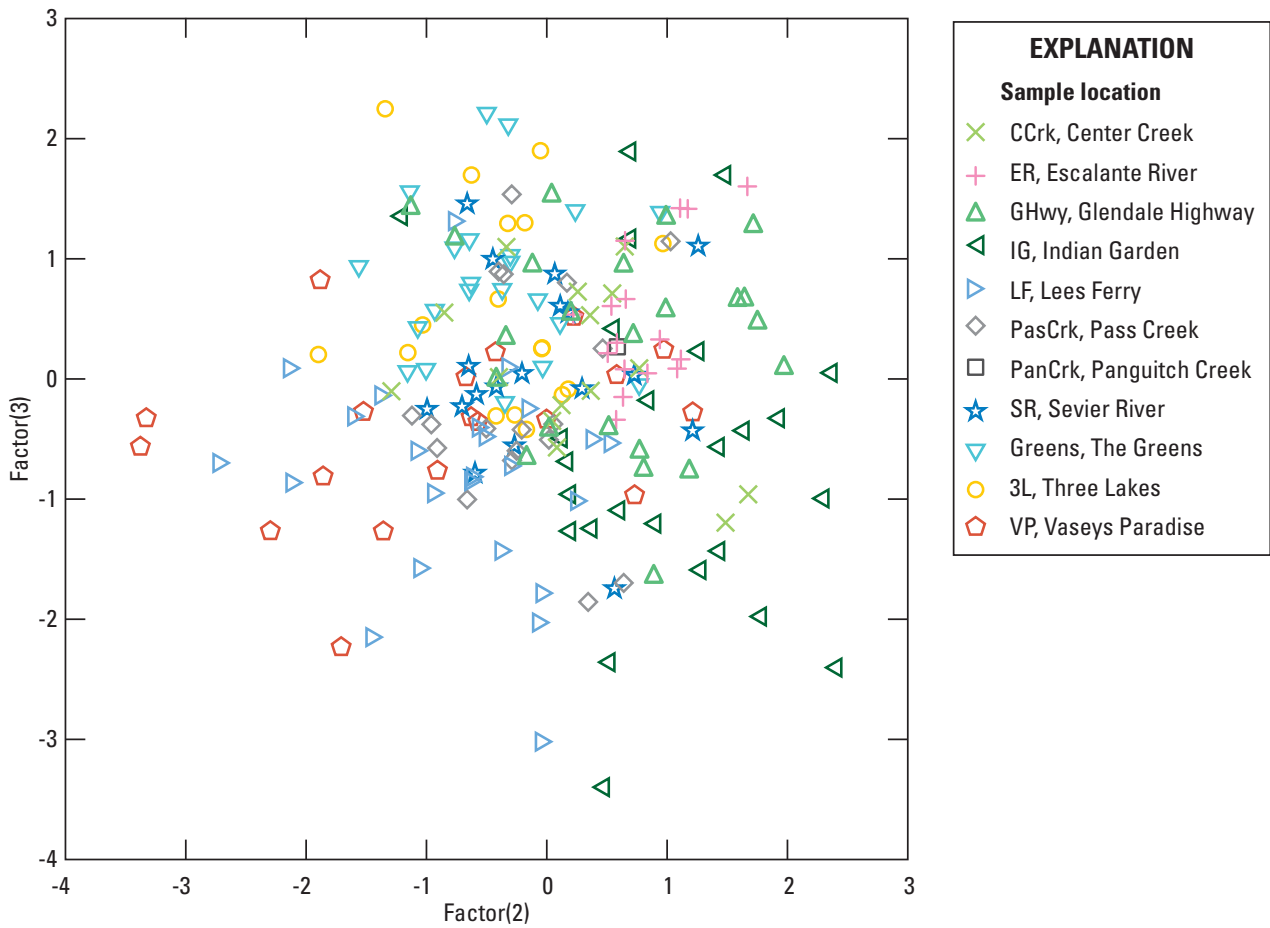

Figure 2. Scores of Oxyloma specimens from all study samples in Arizona and Utah on principal components 2 and 3 ("factors") from principal components analysis. 

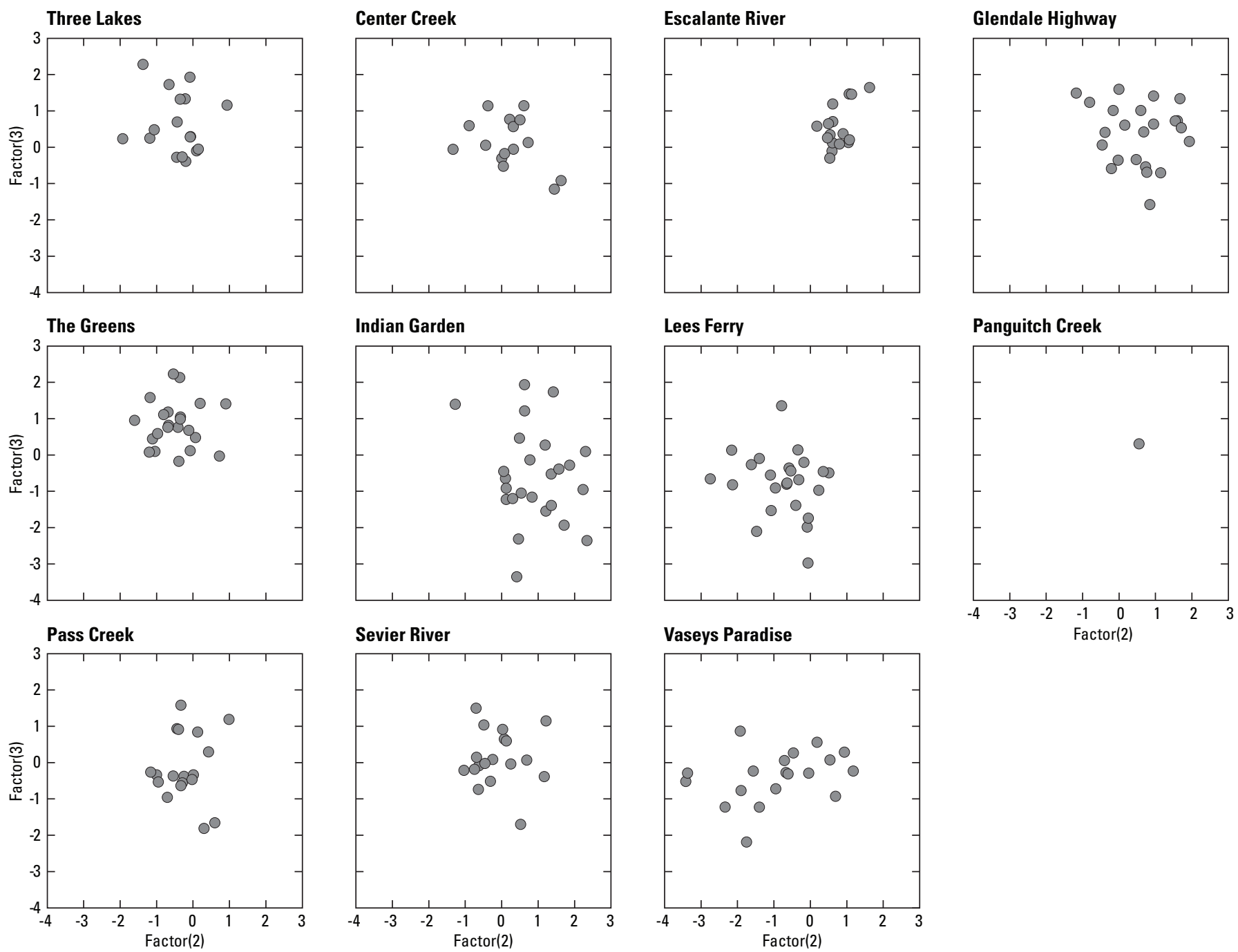

Figure 3. Scores of Oxyloma specimens from individual sampling locations in Arizona and Utah on principal components 2 and 3 ("factors") from principal components analysis. 

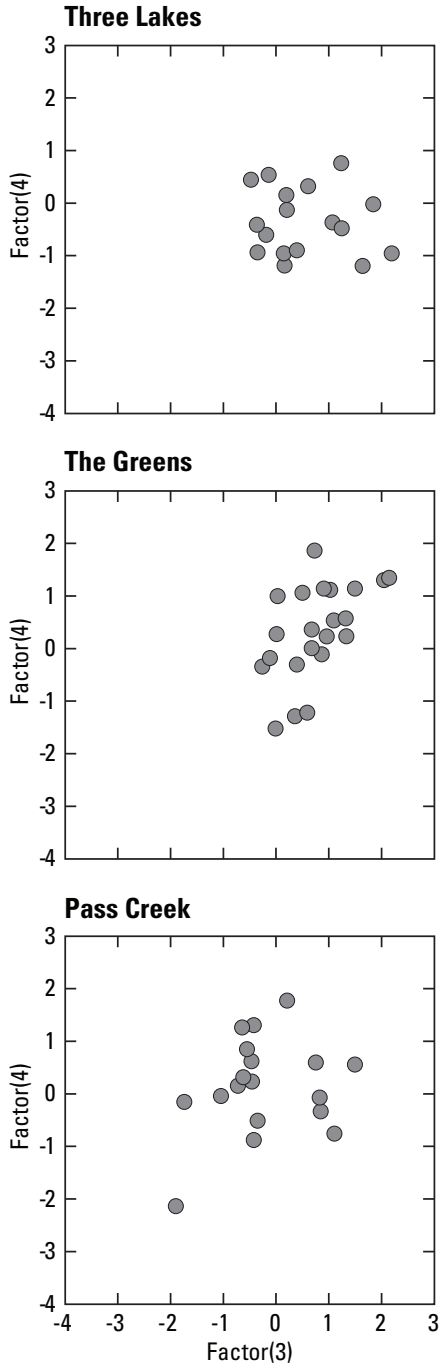

Center Creek

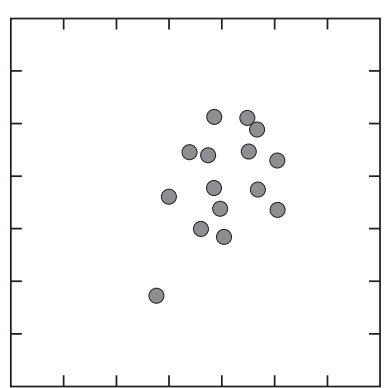

Indian Garden

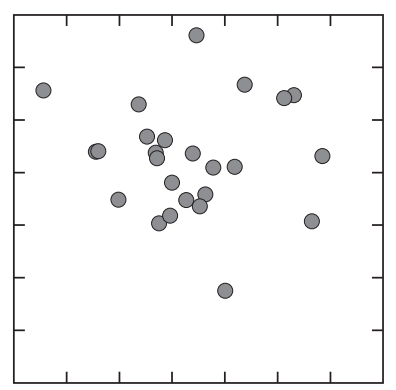

Sevier River

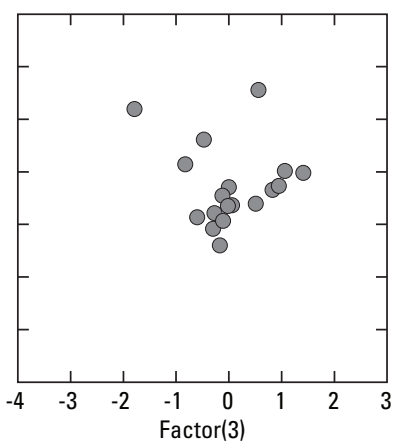

Escalante River

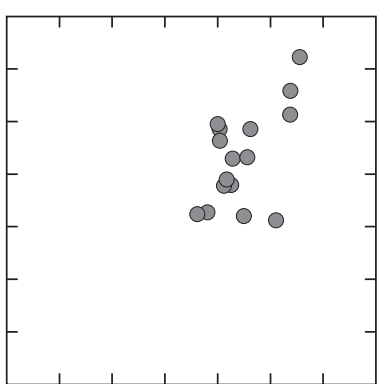

Lees Ferry

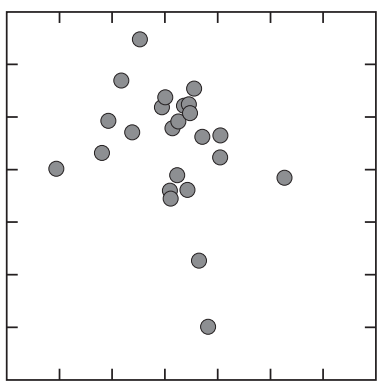

Vaseys Paradise

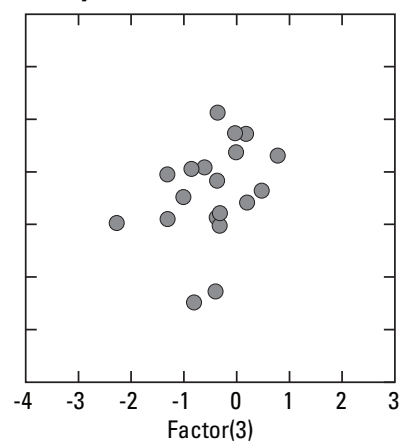

Glendale Highway

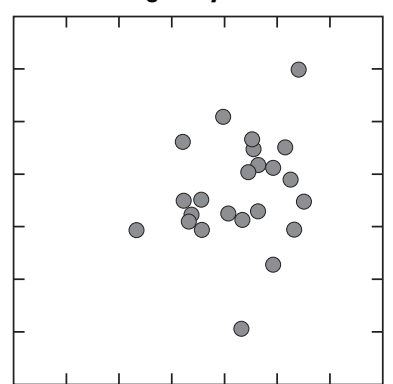

Panguitch Creek

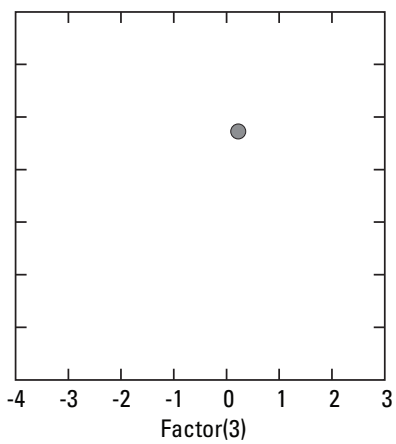

Figure 4. Scores of Oxyloma specimens from sampling locations in Arizona and Utah individually on principal components 3 and 4 ("factors") from principal components analysis. 


\section{Discriminant Analysis}

Discriminant analysis showed that no linear combination of submitted variables reliably classified or discriminated among samples. (The sample from Panguitch Creek, consisting of only one specimen, was excluded from this analysis.)

The first run of discriminant analysis included the coiling parameters of Raup (1966): S, T, and W. These performed very poorly, classifying only 31 percent of specimens into their samples of origin. The best-classified sample was that from Sevier River, with 51 percent of specimens correctly classified; the second best sample was that from Vaseys Paradise, with 47 percent of specimens correctly classified. Adding apical angle (APA) to the analysis raised the total percentage of specimens correctly classified to 34 percent, with 53 percent of specimens from Vaseys Paradise correctly classified.

A second run used the raw dimensions SL, SD, SAL, SAW, and SMD. This set of variables classified 55 percent of all specimens correctly as to their samples of origin. The best-classified samples were those from Sevier River (78 percent), Escalante River (75 percent), Minus 9-Mile Spring (67 percent), and Vaseys Paradise (63 percent).

A third run used the overall size (SS) and shape (SRH, SRA, APY) variables, the kinds of shell morphological features a traditional taxonomist of the school of Pilsbry (1948) probably would have emphasized in preparing his or her descriptions. This set of variables classified 51 percent of all specimens correctly as to their samples of origin. The best-classified samples were those from Sevier River (78 percent), Lees Ferry (67 percent), Escalante River (63 percent), and Vaseys Paradise (63 percent). Jackknifed classification matrices (which used functions from all cases except the one being classified) reduced the total percentages of the first, second, and third runs to 26 percent (29 percent with APA added), 51 percent, and 48 percent, respectively.

Plots of canonical variable scores (for example, fig. 5 , based on the raw dimension dataset, the best-discriminating run of the three) showed substantial overlap among the samples. In this run, five canonical variables were calculated. The first canonical variable is the linear combination of the submitted variables that best discriminated among the groups, the second canonical variable is orthogonal to the first and is the next-best combination of submitted variables, and so on. The first canonical variable accounted for 53.2 percent of the total dispersion of the groups; the first two together accounted

\footnotetext{
${ }^{6}$ Indian Garden was removed as an option in order to keep the number of groups at 10, the maximum allowed by the SYSTAT program for this type of analysis.
}

for 76.4 percent of the total dispersion. These figures, and canonical correlations for the first three canonical variables of $0.766,0.618$, and 0.529 , respectively, represented the moderately good ability of these variables to discriminate among the groups.

The holotype of $O$. h. kanabense is $19.15 \mathrm{~mm}$ long, larger than any specimens collected in the present study. When submitted as an unclassified case to discriminant analysis, it was assigned to Vaseys Paradise in runs using each of the three sets of variables cited earlier in this Discriminant Analysis section. ${ }^{6}$ The same result was achieved with datasets emphasizing and de-emphasizing size ([SL, SD, SAL, SAW, SMD] and [S, T, W, APA], respectively), indicating that the similarity was not owing to shell size alone. When Vaseys Paradise was removed as an option, the analysis classified the holotype in the Pass Creek sample based on variable sets (SL, SD, SAL, SAW, SMD) and (SS, SRH, SRA, APY), and in the Lees Ferry sample based on variable set (S, T, W, APA).

\section{Soft Tissue Anatomy}

It proved difficult to achieve standard anatomical measurements with repeatability because of the flexibility and elasticity of soft tissues. Additionally, the reproductive organs lay within the body cavity in varied orientations, variously compressed within the available space (fig. 6). This "packing problem" made it inadvisable to rely on micrometer or ocular reticule measurements. Additionally, an unknown but considerable amount of ontogenetic variation was present. Half of the specimens in some lots proved, on dissection, to be reproductively immature, even though collected on the same date as other, mature specimens in the population (table 7).

\section{DNA Isolation}

A DNA yield of $1 \mathrm{ng}$ to $19 \mu \mathrm{g}$ of DNA was obtained from each of the 259 samples. This yield was sufficient for all PCR amplifications; however, some individuals did not amplify for all genes or regions attempted (discussed in more detail in Mitochondrial DNA and Nuclear DNA sections below).

\section{Genetic Analyses}

Genetic analyses includes analyses of mitochondrial and nuclear DNA. The mitochondrial genome is composed almost entirely of genes, two of which were examined. The nuclear DNA has a wide variety of DNA types relative to the mitochondria, and many of these types were examined. 
Canonical scores plot

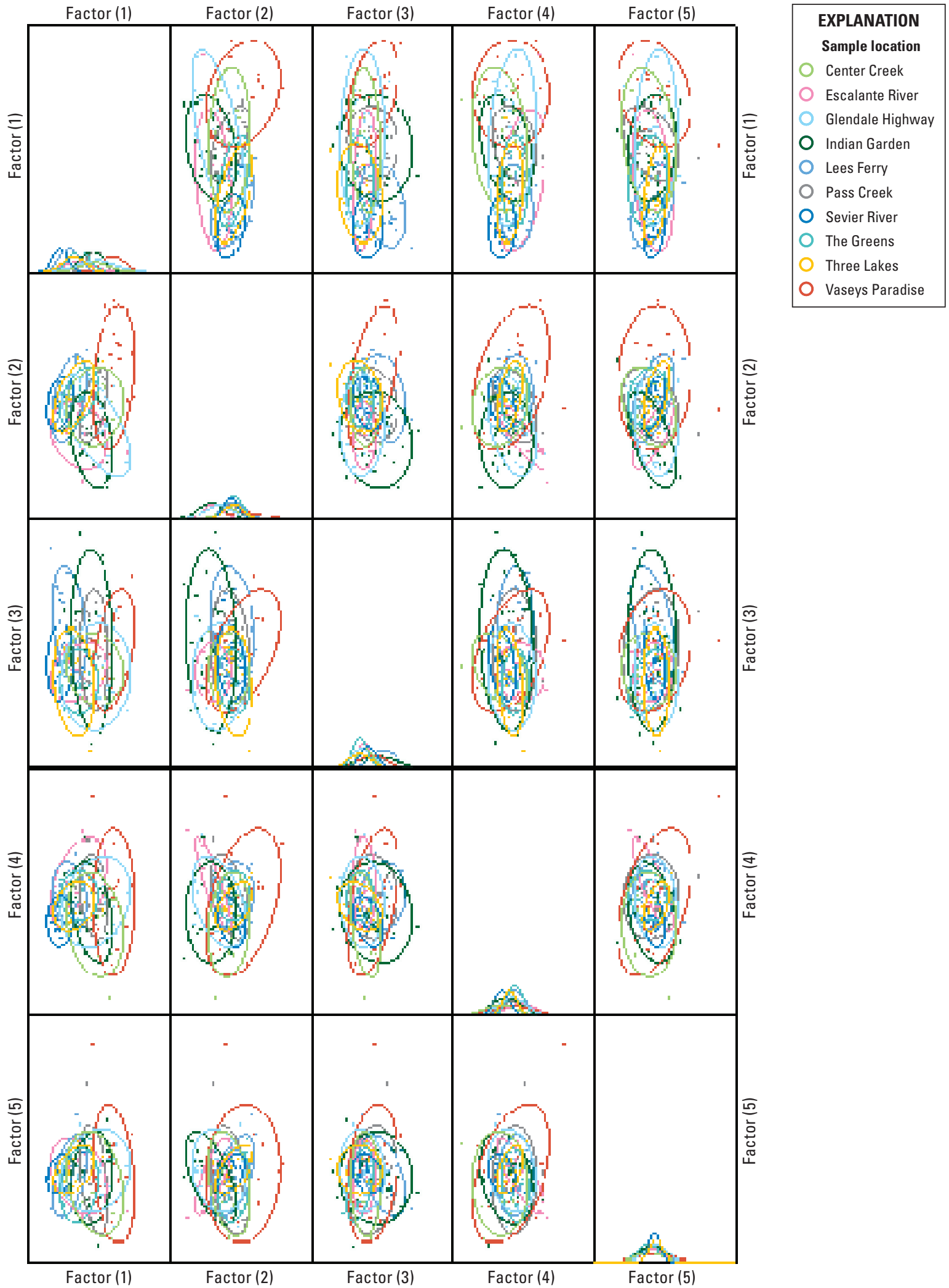

Figure 5. Canonical scores plot of discriminant analysis using shell dimension variables SL (shell length), SD (shell maximum diameter), SAL (shell aperture length), SAW (shell aperture width), and SMD (height of maximum diameter). The axes are the first through fifth canonical variables (factor), and the points are the canonical variable scores of individual ambersnail specimens analyzed for this study. The confidence ellipses are centered on the centroid of each sample. 


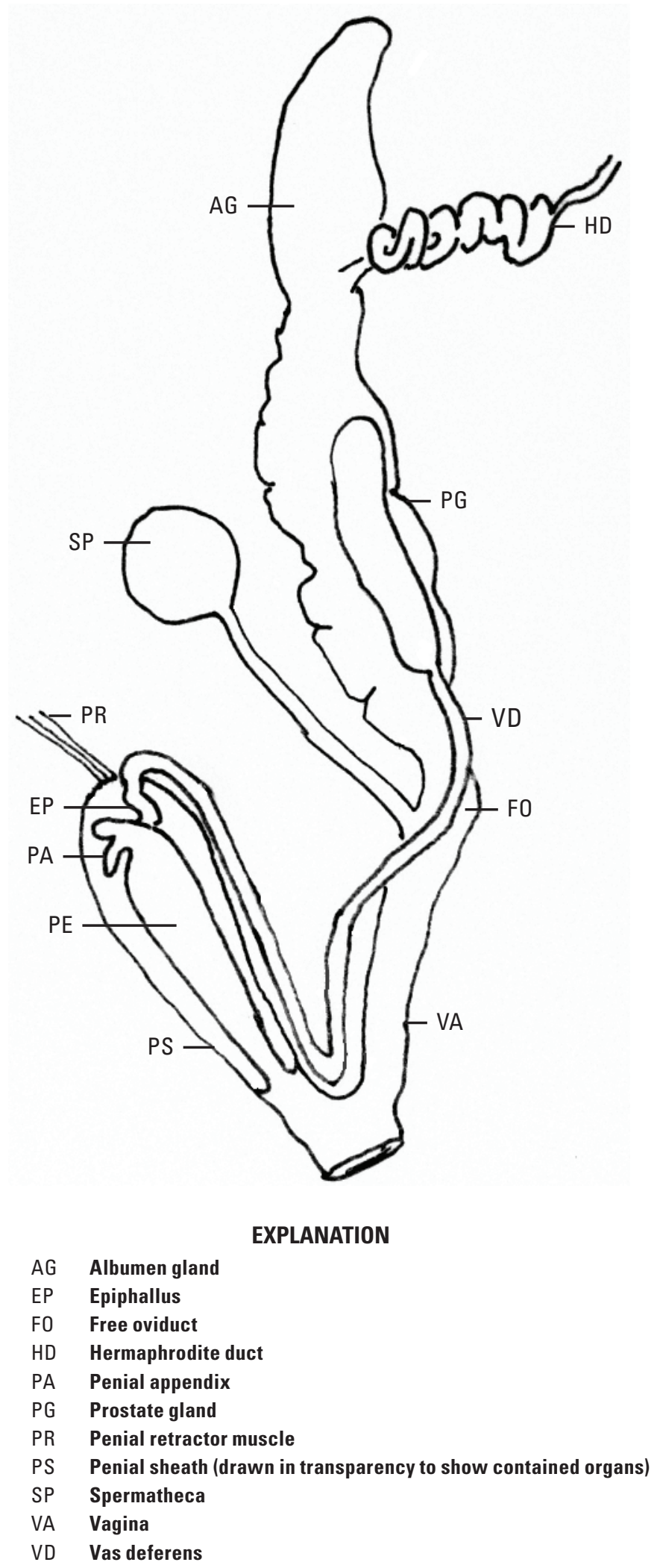

Figure 6. Anatomical features for Oxyloma specimens analyzed for this study. 
Table 7. Summary of Oxyloma anatomical data collected for this study, by sample localities in Arizona and Utah.

[Sample locality: LF, Lees Ferry; IG, Indian Garden; VP, Vaseys Paradise; Greens, The Greens; GHwy, Glendale Highway; CCrk, Center Creek; SR, Sevier River; 3L, Three Lakes; PassCrk, Pass Creek; PanCrk, Panguitch Creek; ER, Escalante River. M antle over lung: , about]

\begin{tabular}{|c|c|c|c|c|c|c|}
\hline $\begin{array}{l}\text { Sample } \\
\text { locality }\end{array}$ & Head-foot color & Mantle color & $\begin{array}{c}\text { Mantle over lung } \\
\text { (percent pigmented) }\end{array}$ & Foot sole & Penial sheath & Penis \\
\hline $\mathrm{LF}$ & $\begin{array}{l}\text { White, with distinct } \\
\text { charcoal-gray } \\
\text { patches of pigment, } \\
\text { tending toward } \\
\text { longitudinal stripes }\end{array}$ & $\begin{array}{l}\text { Lightly dotted with } \\
\text { black and blackish } \\
\text { brown; spots tending } \\
\text { to form branching } \\
\text { network }\end{array}$ & $\sim 60$ & $\begin{array}{l}\text { Tripartite; broad } \\
\text { white central zone } \\
\text { flecked with black, } \\
\text { white lateral zones }\end{array}$ & $\begin{array}{l}\text { Entire, thin, with a } \\
\text { few black flecks of } \\
\text { pigment; summit } \\
\text { acute, with penial } \\
\text { retractor muscle } \\
\text { inserted on it }\end{array}$ & $\begin{array}{l}\text { Cylindrical, simple- } \\
\text { walled, with conical } \\
\text { appendage lateral } \\
\text { to insertion of } \\
\text { epiphallus }\end{array}$ \\
\hline Greens & $\begin{array}{l}\text { Pale buff, with } \\
\text { small amount of } \\
\text { gray pigment } \\
\text { shading toward } \\
\text { head }\end{array}$ & $\begin{array}{l}\text { Right-anterior } 60 \\
\text { percent lightly black } \\
\text { dotted; diagonal } \\
\text { black streak; left- } \\
\text { posterior part with } \\
\text { minor, scattered } \\
\text { black patches }\end{array}$ & $\sim 60$ & $\begin{array}{l}\text { Uniformly pale } \\
\text { buff }\end{array}$ & $\begin{array}{l}\text { Thin, with a few } \\
\text { black flecks of } \\
\text { pigment; summit } \\
\text { acute, with penial } \\
\text { retractor muscle } \\
\text { inserted on it } \\
\text { and apical gap } \\
\text { admitting vas } \\
\text { deferens }\end{array}$ & $\begin{array}{l}\text { Cylindrical, simple- } \\
\text { walled, bearing } \\
\text { small, corkscrew- } \\
\text { coiled, conical } \\
\text { appendage }\end{array}$ \\
\hline GHwy & $\begin{array}{l}\text { White, with gray } \\
\text { pigment shading } \\
\text { toward head; } \\
\text { spotted; nape dark }\end{array}$ & $\begin{array}{l}\text { Entirely blackish } \\
\text { brown with some } \\
\text { darker streaks }\end{array}$ & 100 & $\begin{array}{l}\text { Tripartite; broad } \\
\text { white central zone, } \\
\text { gray pigmented } \\
\text { lateral zones }\end{array}$ & $\begin{array}{l}\text { Thin, with a few } \\
\text { black flecks of } \\
\text { pigment; summit } \\
\text { acute, with penial } \\
\text { retractor muscle } \\
\text { inserted on it } \\
\text { and apical gap } \\
\text { admitting vas } \\
\text { deferens }\end{array}$ & $\begin{array}{l}\text { Cylindrical, simple- } \\
\text { walled, upper } \\
20 \text { percent recurved, } \\
\text { bearing minute } \\
\text { conical appendage }\end{array}$ \\
\hline
\end{tabular}


Table 7. Summary of Oxyloma anatomical data collected for this study, by sample localities in Arizona and Utah.-Continued

[Sample locality: LF, Lees Ferry; IG, Indian Garden; VP, Vaseys Paradise; Greens, The Greens; GHwy, Glendale Highway; CCrk, Center Creek; SR, Sevier River; 3L, Three Lakes; PassCrk, Pass Creek; PanCrk, Panguitch Creek; ER, Escalante River. M antle over lung: , about]

\begin{tabular}{|c|c|c|c|c|c|c|}
\hline $\begin{array}{l}\text { Sample } \\
\text { locality }\end{array}$ & Head-foot color & Mantle color & $\begin{array}{c}\text { Mantle over lung } \\
\text { (percent pigmented) }\end{array}$ & Foot sole & Penial sheath & Penis \\
\hline CCrk & $\begin{array}{l}\text { Gray, slightly darker } \\
\text { toward head }\end{array}$ & $\begin{array}{l}\text { Closely, uniformly, } \\
\text { black dotted }\end{array}$ & 100 & $\begin{array}{l}\text { Tripartite; broad } \\
\text { pale buff central } \\
\text { zone faintly mottled } \\
\text { with gray, gray } \\
\text { pigmented lateral } \\
\text { zones }\end{array}$ & $\begin{array}{l}\text { Entire, thin, with } \\
\text { numerous black } \\
\text { flecks of pigment; } \\
\text { summit acute, with } \\
\text { penial retractor } \\
\text { muscle inserted on it }\end{array}$ & $\begin{array}{l}\text { Cylindrical, simple- } \\
\text { walled, upper } \\
20 \text { percent recurved, } \\
\text { bearing minute, } \\
\text { reflexed appendage }\end{array}$ \\
\hline $3 \mathrm{~L}$ & $\begin{array}{l}\text { White to pale buff, } \\
\text { with small amount } \\
\text { of gray pigment } \\
\text { shading toward } \\
\text { head }\end{array}$ & $\begin{array}{l}\text { Anterior margin } \\
\text { with lobate pigment } \\
\text { blotches; right half } \\
\text { lightly black dotted; } \\
\text { antero-posterior } \\
\text { medial black streak; } \\
\text { left half with } \\
\text { scattered black } \\
\text { patches }\end{array}$ & $\sim 40$ & $\begin{array}{l}\text { Uniformly pale } \\
\text { buff }\end{array}$ & $\begin{array}{l}\text { Entire, thin, } \\
\text { unpigmented; } \\
\text { summit acute, with } \\
\text { penial retractor } \\
\text { muscle inserted } \\
\text { on it }\end{array}$ & $\begin{array}{l}\text { Cylindrical, } \\
\text { simple-walled, } \\
\text { bearing hammer- } \\
\text { shaped, reflexed } \\
\text { appendage }\end{array}$ \\
\hline PassCrk & $\begin{array}{l}\text { Gray, slightly } \\
\text { darker toward head }\end{array}$ & $\begin{array}{l}\text { Closely, uniformly, } \\
\text { black dotted }\end{array}$ & 100 & $\begin{array}{l}\text { Tripartite; flecked } \\
\text { with charcoal-gray } \\
\text { pigmernt, flecks } \\
\text { slightly larger in } \\
\text { lateral zones than in } \\
\text { central zone }\end{array}$ & $\begin{array}{l}\text { Entire, thin, with a } \\
\text { few black flecks of } \\
\text { pigment; summit } \\
\text { rounded, admitting } \\
\text { vas deferens }\end{array}$ & $\begin{array}{l}\text { Cylindrical, } \\
\text { simple-walled, } \\
\text { with prominent, } \\
\text { conical reflexed } \\
\text { appendage lateral } \\
\text { to insertion of } \\
\text { epiphallus }\end{array}$ \\
\hline PanCrk & $\begin{array}{l}\text { Gray, slightly } \\
\text { darker toward head }\end{array}$ & $\begin{array}{l}\text { Closely, uniformly, } \\
\text { blackish-brown } \\
\text { dotted }\end{array}$ & 100 & $\begin{array}{l}\text { Tripartite; broad } \\
\text { white central zone, } \\
\text { lightly gray flecked } \\
\text { lateral zones }\end{array}$ & $\begin{array}{l}\text { Entire, thin, with a } \\
\text { few black flecks of } \\
\text { pigment; summit } \\
\text { rounded, admitting } \\
\text { vas deferens }\end{array}$ & $\begin{array}{l}\text { Cylindrical, simple- } \\
\text { walled, upper } \\
20 \text { percent recurved, } \\
\text { bearing reflexed } \\
\text { appendage }\end{array}$ \\
\hline ER & $\begin{array}{l}\text { White, with gray } \\
\text { pigment shading } \\
\text { toward head; } \\
\text { vertically striped; } \\
\text { nape dark }\end{array}$ & $\begin{array}{l}\text { Closely, uniformly, } \\
\text { black dotted }\end{array}$ & 100 & $\begin{array}{l}\text { Tripartite; broad } \\
\text { white central zone, } \\
\text { gray pigmented } \\
\text { lateral zones }\end{array}$ & $\begin{array}{l}\text { Entire, thin, with a } \\
\text { few black flecks of } \\
\text { pigment; summit } \\
\text { acute, with penial } \\
\text { retractor muscle } \\
\text { inserted on it }\end{array}$ & $\begin{array}{l}\text { Cylindrical, simple- } \\
\text { walled, upper } \\
20 \text { percent recurved, } \\
\text { bearing minute, } \\
\text { reflexed appendage }\end{array}$ \\
\hline
\end{tabular}


Table 7. Summary of Oxyloma anatomical data collected for this study, by sample localities in Arizona and Utah.-Continued

[Sample locality: LF, Lees Ferry; IG, Indian Garden; VP, Vaseys Paradise; Greens, The Greens; GHwy, Glendale Highway; CCrk, Center Creek; SR, Sevier River; 3L, Three Lakes; PassCrk, Pass Creek; PanCrk, Panguitch Creek; ER, Escalante River. M antle over lung: , about]

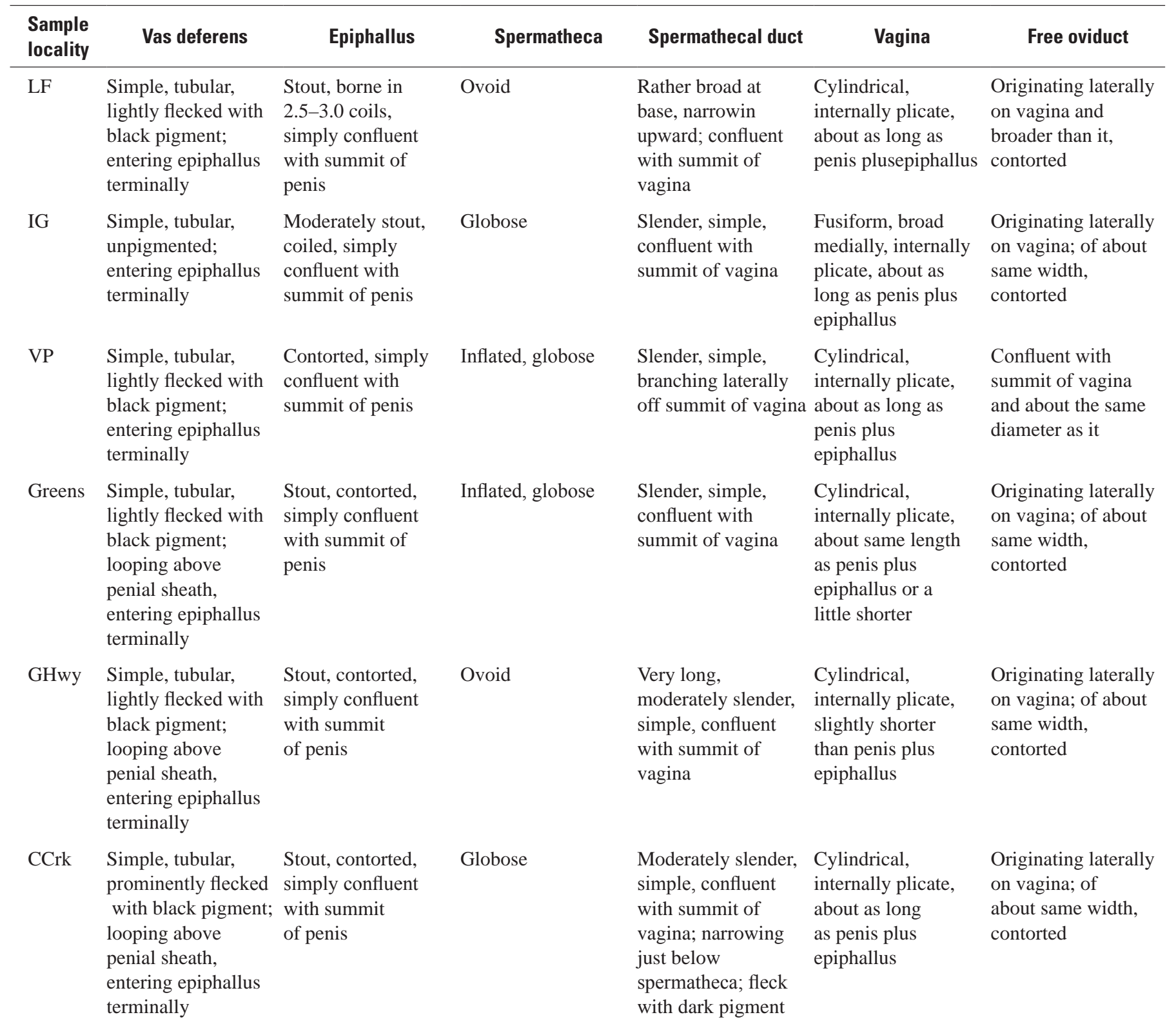


Table 7. Summary of Oxyloma anatomical data collected for this study, by sample localities in Arizona and Utah.—Continued

[Sample locality: LF, Lees Ferry; IG, Indian Garden; VP, Vaseys Paradise; Greens, The Greens; GHwy, Glendale Highway; CCrk, Center Creek; SR, Sevier River; 3L, Three Lakes; PassCrk, Pass Creek; PanCrk, Panguitch Creek; ER, Escalante River. M antle over lung: , about]

\begin{tabular}{|c|c|c|c|c|c|c|}
\hline $\begin{array}{l}\text { Sample } \\
\text { locality }\end{array}$ & Vas deferens & Epiphallus & Spermatheca & Spermathecal duct & Vagina & Free oviduct \\
\hline SR & $\begin{array}{l}\text { Simple, tubular, } \\
\text { prominently flecked } \\
\text { with black pigment; } \\
\text { looping above } \\
\text { penial sheath, } \\
\text { entering epiphallus } \\
\text { terminally }\end{array}$ & $\begin{array}{l}\text { Stout, contorted, } \\
\text { simply confluent } \\
\text { with summit } \\
\text { of penis }\end{array}$ & Ovoid & $\begin{array}{l}\text { Long, moderately } \\
\text { slender, simple, } \\
\text { confluent with } \\
\text { summit of vagina; } \\
\text { narrowing just } \\
\text { below spermatheca }\end{array}$ & $\begin{array}{l}\text { Fusiform, internally } \\
\text { plicate, about as } \\
\text { long as penis plus } \\
\text { epiphallus }\end{array}$ & $\begin{array}{l}\text { Originating laterally } \\
\text { on vagina; of about } \\
\text { same width, } \\
\text { contorted }\end{array}$ \\
\hline $3 \mathrm{~L}$ & $\begin{array}{l}\text { Simple, tubular, } \\
\text { lightly flecked with } \\
\text { black pigment; } \\
\text { entering epiphallus } \\
\text { terminally }\end{array}$ & $\begin{array}{l}\text { Stout, contorted, } \\
\text { simply confluent } \\
\text { with summit } \\
\text { of penis }\end{array}$ & Inflated, globose & $\begin{array}{l}\text { Moderately slender, } \\
\text { simple, confluent } \\
\text { with summit of } \\
\text { vagina; narrowing } \\
\text { just below } \\
\text { spermatheca }\end{array}$ & $\begin{array}{l}\text { Cylindrical, about as } \\
\text { long as penis plus } \\
\text { epiphallus }\end{array}$ & $\begin{array}{l}\text { Of about same } \\
\text { diameter as vagina, } \\
\text { contorted }\end{array}$ \\
\hline PanCrk & $\begin{array}{l}\text { Simple, tubular, } \\
\text { lightly flecked with } \\
\text { black pigment; } \\
\text { entering epiphallus } \\
\text { terminally }\end{array}$ & $\begin{array}{l}\text { Stout, contorted, } \\
\text { simply confluent } \\
\text { with summit } \\
\text { of penis }\end{array}$ & Globose & $\begin{array}{l}\text { Thick (about as thick } \\
\text { as main body of } \\
\text { penis), confluent } \\
\text { with summit of } \\
\text { vagina; flecked } \\
\text { with black }\end{array}$ & $\begin{array}{l}\text { Fusiform, broad } \\
\text { medially, internally } \\
\text { plicate, about as } \\
\text { long as penis plus } \\
\text { epiphallus }\end{array}$ & $\begin{array}{l}\text { Originating } \\
\text { laterally on } \\
\text { vagina, of about } \\
\text { same diameter, } \\
\text { contorted }\end{array}$ \\
\hline ER & $\begin{array}{l}\text { Simple, tubular, } \\
\text { lightly flecked with } \\
\text { black pigment; } \\
\text { entering epiphallus } \\
\text { terminally }\end{array}$ & $\begin{array}{l}\text { Stout, contorted, } \\
\text { simply confluent } \\
\text { with summit } \\
\text { of penis }\end{array}$ & Inflated, globose & $\begin{array}{l}\text { Moderately slender, } \\
\text { simple, confluent } \\
\text { with summit of } \\
\text { vagina; narrowing } \\
\text { just below } \\
\text { spermatheca }\end{array}$ & $\begin{array}{l}\text { Cylindrical, } \\
\text { internally plicate, } \\
\text { about as long as } \\
\text { penis plus } \\
\text { epiphallus }\end{array}$ & $\begin{array}{l}\text { Broader than vagina, } \\
\text { contorted }\end{array}$ \\
\hline
\end{tabular}


Table 7. Summary of Oxyloma anatomical data collected for this study, by sample localities in Arizona and Utah.—Continued

[Sample locality: LF, Lees Ferry; IG, Indian Garden; VP, Vaseys Paradise; Greens, The Greens; GHwy, Glendale Highway; CCrk, Center Creek; SR, Sevier River; 3L, Three Lakes; PassCrk, Pass Creek; PanCrk, Panguitch Creek; ER, Escalante River. M antle over lung: , about]

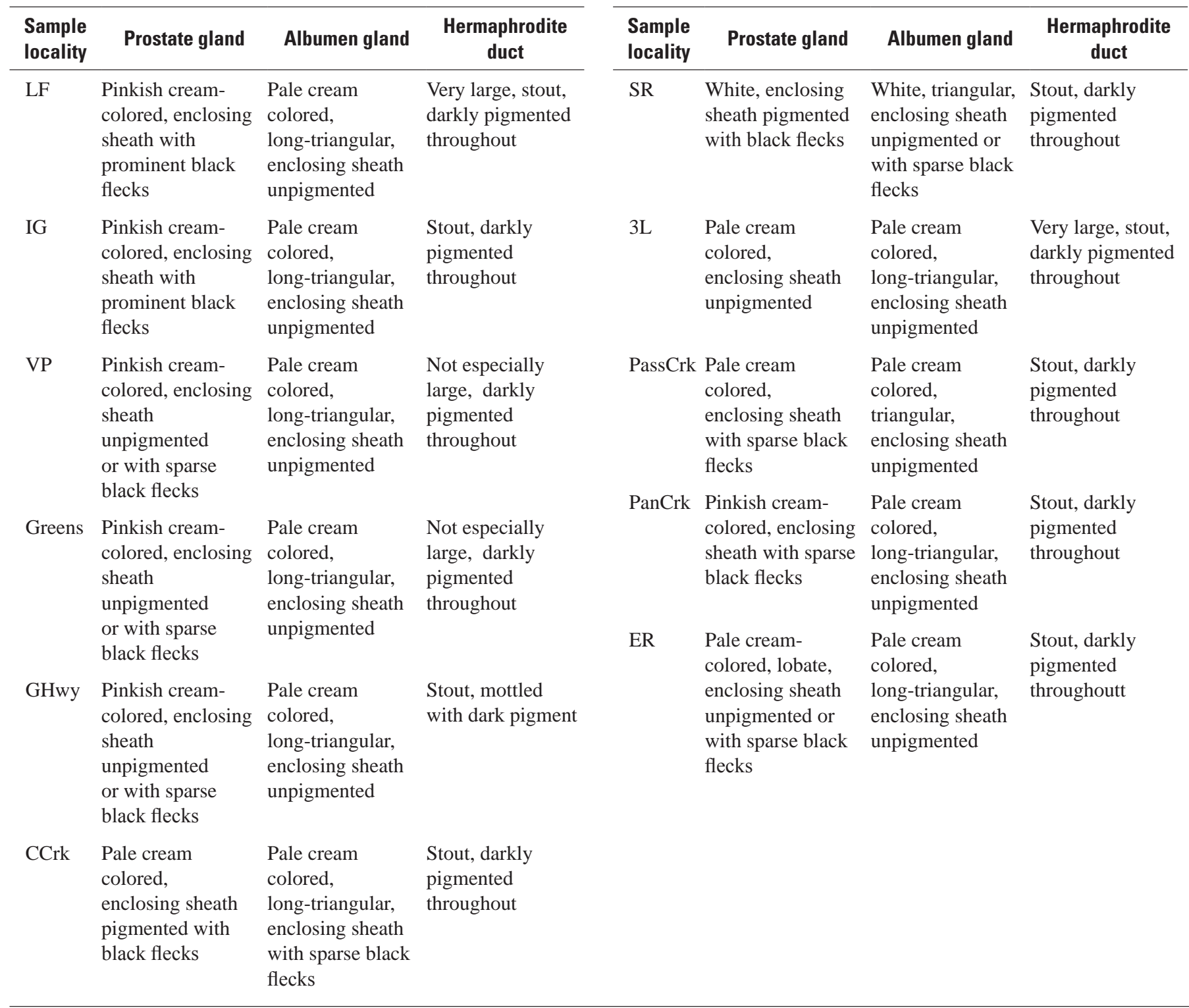




\section{Mitochondrial DNA}

This study examined two mitochondrial regions: the cytochrome oxidase subunit I (COI) and cytochrome $b$ (cyt $b$ ) genes. Catinella, Succinea, and Neosuccinea sequences from GenBank ${ }^{\circledR}$ were included in a single mtDNA analysis to generate a maximum likelihood phylogenetic tree indicating the location of the outgroup root (ig. 7). In this tree, the Catinella sequence from GenBank ${ }^{\circledR}$ is the first to branch off (most ancestral), followed by a clade of five Catinella sequences from Batch 1 (Sonoita Creek), and then a group containing the other two outgroup sequences from GenBank ${ }^{\circledR}$, Succinea and Neosuccinea. One individual from Batch 12 (Escalante River), 12-6, clustered with the Batch 1 clade in this tree.

The COI fragment had a total length of 510 bp with 131 variable sites of which 57 were parsimony informative. From Sevier River, Pass Creek, and Escalante River, we obtained only five, nine, and seven sequences, respectively. Samples from Panguitch Creek failed to amplify completely (table 2). The analyzed COI dataset represented 141 specimens that successfully amplified for a total of 48 different haplotypes.

The cyt $b$ fragment was 366 bp long and had 99 variable sites of which 30 were parsimony informative. From Three Lakes, we obtained only four sequences, and from Panguitch Creek, we obtained only 2 sequences. There are 163 specimens that successfully amplified for a total of 32 haplotypes present in the cyt $b$ dataset. Three haplotypes were shared by specimens from different locations: H2-1 includes 21 specimens from Lees Ferry, one specimen from Vaseys Paradise, and one specimen from Sevier River; H10-1 includes six specimens from Pass Creek, two from Panguitch Creek, and one from Sevier River; H9-5 includes four specimens from Three Lakes and one from Sevier River.

AMOVA results for the concatenated mitochondrial loci indicated that greater than or equal to 71 percent of the observed variation existed among populations with less than or equal to 29 percent within populations (table 8). Pairwise genetic distance $\left(\mathrm{F}_{\mathrm{ST}}\right)$ MDS plots (not shown) revealed no obvious groupings. However, the position of the Vaseys Paradise population is most distant from all other populations.

Pairwise genetic distance values (estimated using $\mathrm{F}_{\mathrm{ST}}$ ) compared to linear geographic distance (kilometers) between populations in a Mantel test showed a slight but statistically significant positive correlation between genetic and geographic distance for cyt $b$ (average coefficient of determination $\left[\mathrm{r}^{2}\right]$ less than or equal to 0.08 ; table 8). Thus, only 8 percent of the genetic distance variance observed could be explained by geographic distance for cyt $b$ data. The analysis was performed separately on each gene.

Signals for population expansions with (significant) negative values for Tajima's D (table 9), Fu's $\mathrm{F}_{\mathrm{s}}$ (table 10), and (significant) small positive values for Roza's $R_{2}$ (table 11) were found in Lees Ferry, Vaseys Paradise, The Greens, Glendale Highway, Center Creek, Three Lakes, Pass Creek and Escalante River. The only population that did not show such values was Indian Garden. The more conservative mismatch distribution (not shown) indicated a deviation from the multimodal distribution of a stable population at the COI locus of the Glendale Highway population only.

Table 8. Analysis of molecular variance used to estimate genetic variation within versus among populations; and Mantel test to assess correlation between genetic distance and geographic distance for six different mitochondrial and nuclear DNA loci and one concatenated mtDNA dataset used to analyze genetic variation in Oxyloma populations.

[L ocus: COI, cytochrome oxidase subunit I gene; cyt $b$, cytochrome $b$ gene; mtconcat, mitochondrial genes concatenated; 356, random ambersnail nuclear clone 356; 458, random ambersnail nuclear clone 458; ITS, ribosomal DNA first and second internal transcribed spacer; S7, ribosomal gene introns S7-1 and S7-2. AM OVA: Analysis of molecular variance; $\mathbf{F}_{\mathbf{S T}}$, F statistic indicating genetic distance of a subpopulation relative to the total of all populations; km, kilometer; $<$, less than]

\begin{tabular}{lcc}
\hline \multirow{2}{*}{ Locus } & $\begin{array}{c}\text { AMOVA } \\
\text { among populations }\end{array}$ & $\begin{array}{c}\text { Mantel test } \\
\text { pairwise } \mathbf{F}_{\mathbf{S T}} / \mathbf{l o g} \mathbf{~ k m}\end{array}$ \\
\cline { 2 - 3 } & Estimated using $\mathbf{F}_{\mathbf{S T}}$ & $\mathbf{r}^{\mathbf{2}}$ \\
\hline COI & 75.4 & ${ }^{1} 0.06$ \\
cyt $b$ & 66.2 & ${ }^{2} 0.08$ \\
mtconcat & 71.7 & ${ }^{3} 0.05$ \\
356 & 67.9 & ${ }^{3} 0.01$ \\
458 & 83.0 & 20.19 \\
ITS & 97.2 & ${ }^{3} 0.02$ \\
S7 & 71.8 & ${ }^{2} 0.07$ \\
\hline
\end{tabular}

\footnotetext{
${ }^{1} 0.05<\mathrm{p}<0.10$

${ }^{2} \mathrm{p}<0.05$

${ }^{3}$ Not significant
} 


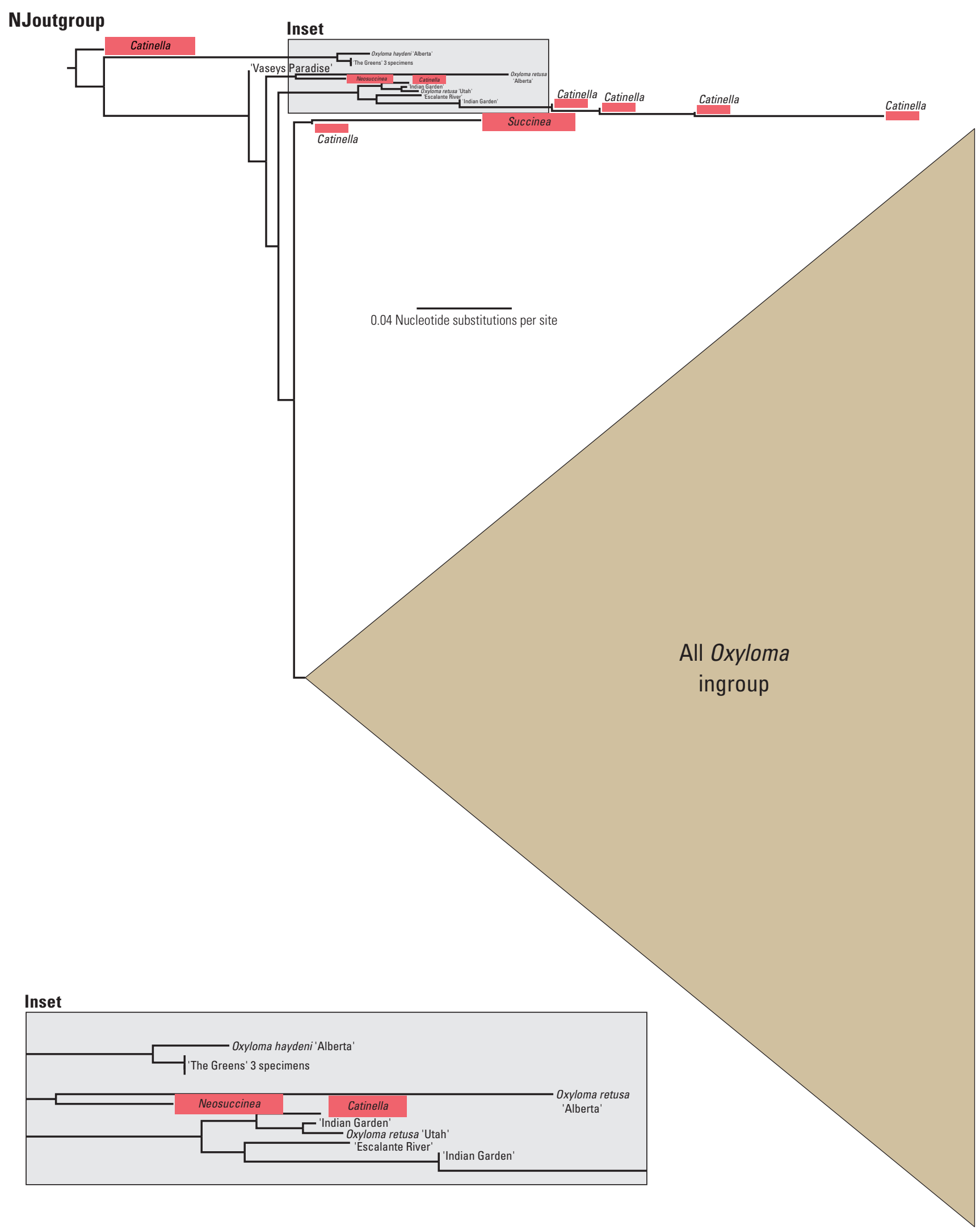

Figure 7. Maximum likelihood tree diagram showing the concatenated mitochondrial DNA dataset (mtconcat) including the cytochrome oxidase subunit I (COI) and cytochrome $b$ (cyt $b$ ) genes for Oxyloma populations, used to show position of the outgroups. All 12 ambersnail populations (12 Batches) are included in the tree along with several outgroup species. One Catinella "outgroup" sequence (the first branch of the tree and most ancestral group; far left) is shown in red, and two other "outgroup" sequences from GenBank ${ }^{\circledR}$, Succinea and Neosuccinea, also are shown in red. The triangle represents all ingroup populations of Kanab ambersnail, with the width of the triangle indicating the total evolutionary divergence of that ambersnail group. 


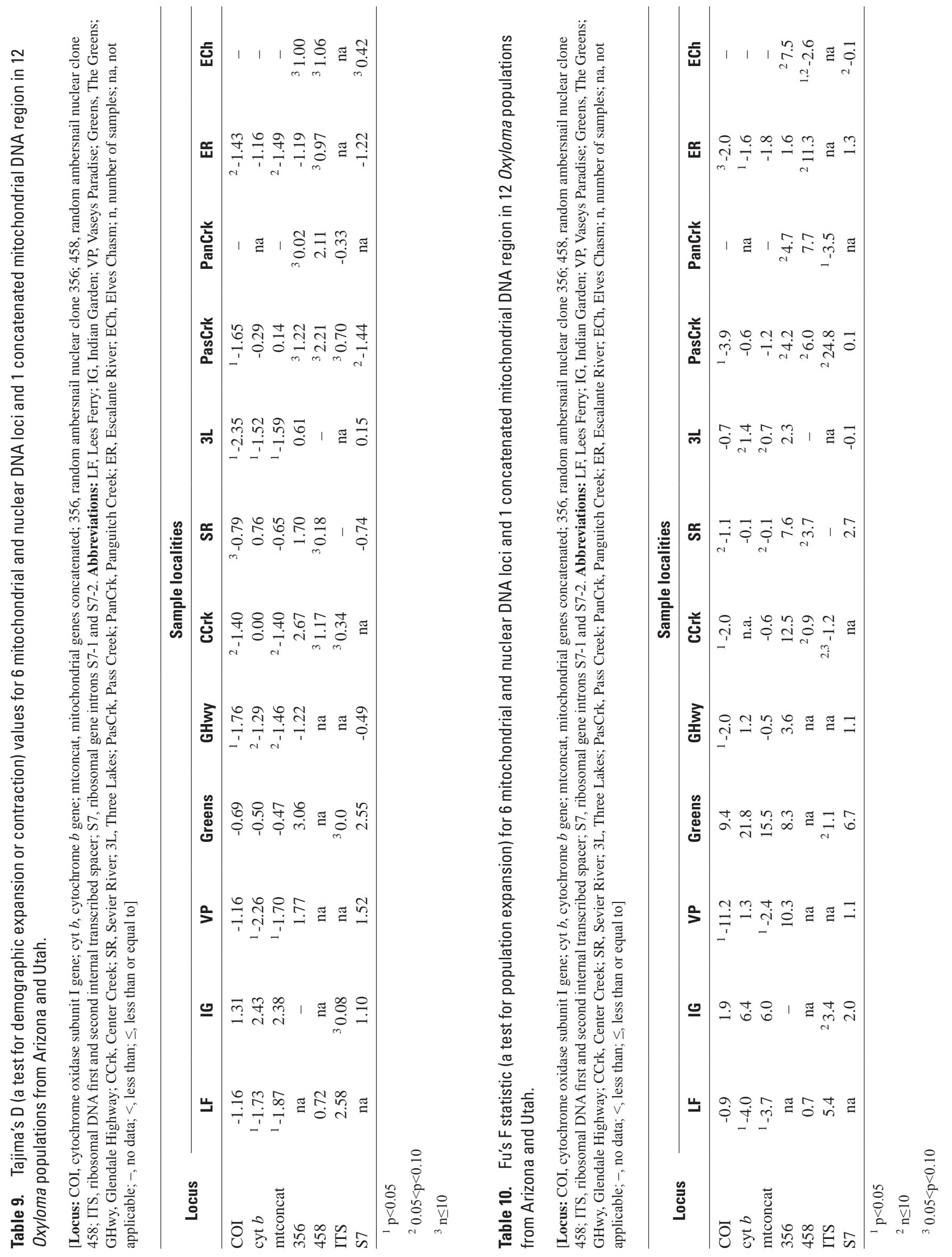




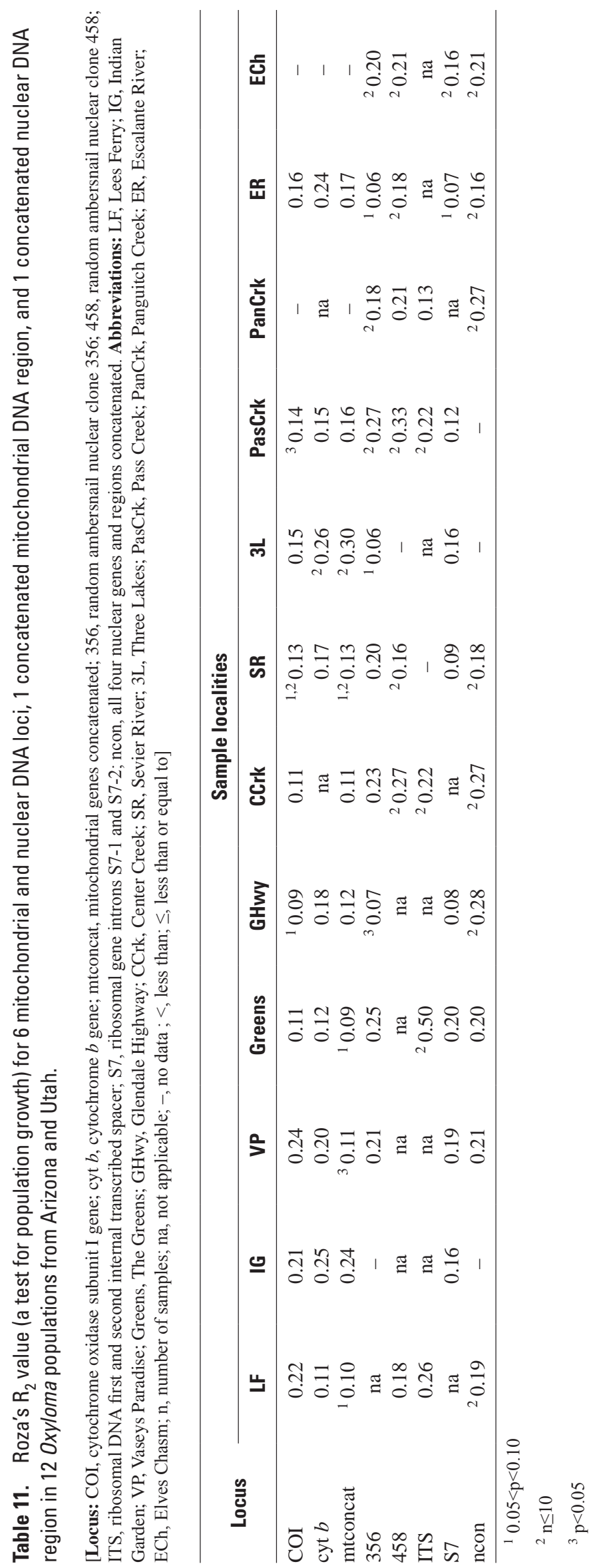


Figure 8 shows the Bayesian tree for our COI dataset. NJ and MP trees also were generated but are not shown. All trees show structure between different populations, mostly at a shallow level. All analyses agreed in that Vaseys Paradise specimens formed a monophyletic group but were not monophyletic with Three Lakes and all specimens from The Greens. The Greens were divided into two separate groups: one haplotype (H5-4) of three specimens that were monophyletic with the Vaseys Paradise population, and one monophyletic group that consists of seven different haplotypes. The Three Lakes population was not monophyletic in the Bayesian analysis. One specimen (9-12) from Three Lakes showed no close relationship with the other specimens of the group, as seen by the Three Lakes individual (yellow) that is placed on a branch far away from all other Three Lakes (yellow) individuals in the tree.

A haplotype network (fig. 9) resulted in a similar pattern with specimens from Vaseys Paradise showing the second largest distance from the network center. The largest distance shown connected a haplotype from The Greens (H5-4) to the network. The third largest distance was shown by a branch leading to one Three Lakes specimen (9-12).

Phylogenetic trees generated for cyt $b$ used the same three algorithms. The Bayesian tree is shown in fig. 10. Phylogenetic analyses supported the monophyly of the Vaseys Paradise specimens with the exception of one specimen that grouped with Lees Ferry individuals (haplotype H2-1) and one Sevier River individual. Otherwise, the results showed a similar pattern of shallow structure as observed in the COI fragment.

The cyt $b$ haplotype network (fig. 11) reflected the same structure seen in the phylogenetic analyses. Haplotypes corresponded largely with geographic populations. The long branches (many mutational steps) leading to Vaseys Paradise, one Three Lakes specimen (9-12), and to a group of three specimens from The Greens (haplotypes H5-4), indicate these to be the most divergent haplotypes in this study area.

As mitochondrial loci are linked, we also concatenated the COI and cyt $b$ sequences for each individual. We excluded samples with missing sequences from this dataset. This resulted in only four concatenated sequences for Sevier River, two for Three Lakes, eight for Pass Creek and seven for Escalante River. As no COI sequences for Panguitch Creek samples were generated, no concatenated sequences for this location were analyzed.

The concatenated mitochondrial loci sequence represents 876 bp with 85 informative nucleotide polymorphisms. A total of 116 specimens and 53 haplotypes are observed. The phylogenetic analyses for this concatenated dataset supported predominately shallow structure for each sampling location. A distance matrix for this dataset is shown in table 12. The Vaseys Paradise population was monophyletic and The Greens population was polyphyletic. In the NJ and MP trees (not shown), three specimens from The Greens (haplotype H5-4) were monophyletic with the Vaseys Paradise population. In the Bayesian analysis, this relationship was unresolved (fig. 12). The position of one Three Lakes specimen (9-12) in all three mtDNA analyses showed it as unrelated to the rest of the Three Lakes haplotypes and more closely related to the three highly divergent The Greens specimens. Additionally, two specimens from Sevier River (8-9 and 8-10) were monophyletic with the rest of the Three Lakes specimens.

The haplotype network for the concatenated dataset (fig. 13) mainly showed the same pattern as the single locus networks. Geographic units (populations) corresponded largely with the haplotype network. Three specimens from The Greens (haplotype H5-4) were positioned at the end of an extraordinarily long branch, indicating many mutational steps between them and the other samples. All specimens from Vaseys Paradise and one specimen from Three Lakes showed the next-largest number of mutational steps.

Overall, the mitochondrial data showed shallow structure corresponding with populations. Exceptions were three specimens from The Greens (haplotype H5-4) and one specimen from Three Lakes. Taken together, these exceptions showed positions in the haplotype network that were supported by a considerably larger number of mutational steps than between other groups in this study. Interesting “outliers” were one specimen from Vaseys Paradise sharing its cyt $b$ haplotype with specimens of the Lees Ferry population. Some specimens from the Sevier River population also were interesting, as they seemed to be monophyletic with other populations. The Sevier River population was the only population that was widely distributed over the phylogenetic trees and haplotype networks.

\section{Nuclear DNA}

The nuclear DNA regions examined in this study, and presented here, are markers that span genes (coding regions), non-coding regions, repetitive regions, single-copy regions, and multilocus markers. Taken together, these markers provide a more complete and scientifically rigorous analysis than any of these markers alone. 
COI

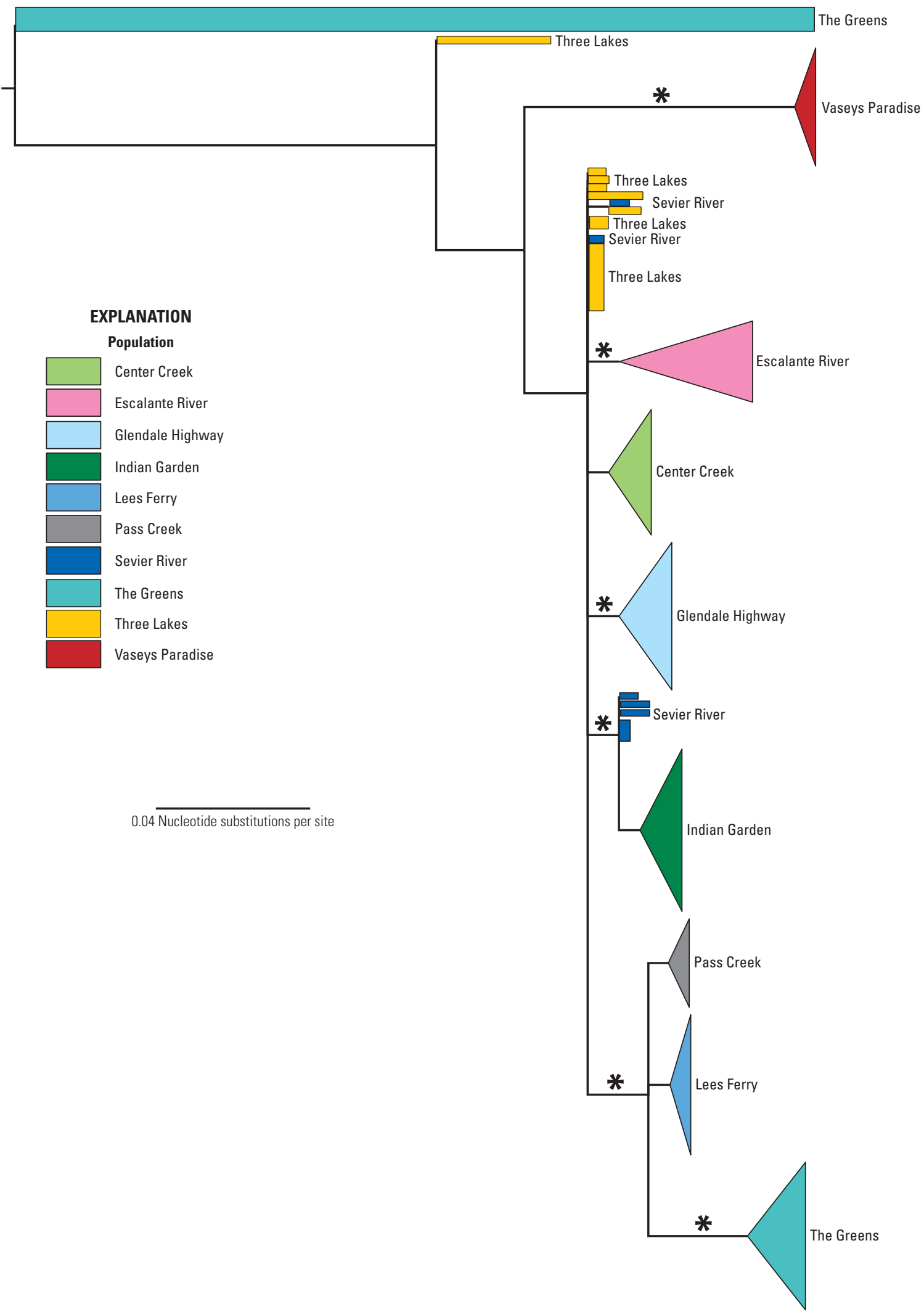

Figure 8. Bayesian (MB) 50-percent majority rule consensus tree diagram showing mitochondrial cytochrome oxidase subunit I gene (COI) dataset analyzed for Oxyloma populations sampled. The Panguitch Creek, Utah, population is not included in the tree. Asterisks indicate well-supported nodes (Bayesian posterior probability greater than 90 percent). Rectangles and triangles represent individuals and populations, respectively. The height of a rectangle or triangle indicates the relative number of individuals represented by the sample (larger height is more individuals), and the width of a rectangle or triangle indicates the relative evolutionary divergence (larger width is more divergence). 


\section{COI}

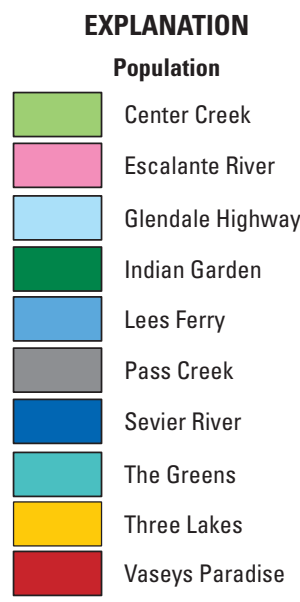

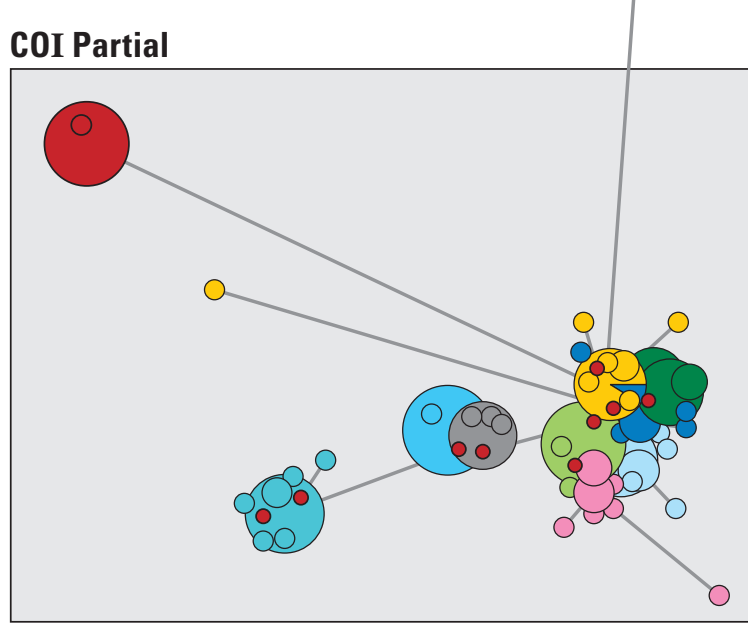

Figure 9. Median-joining haplotype network diagram showing mitochondrial cytochrome oxidase subunit I gene (COI) dataset analyzed for Oxyloma populations sampled. COI partial (in the box) represents an enlargement of the lower part of the complete network. Color codes represent the different populations and are the same as in the COI Bayesian tree (fig. 8). The size of each circle is proportional to the number of individuals containing each haplotype, respectively. Branch lengths are proportional to mutational steps, and the shortest branch is one step. 
COI

\section{Col Partial}

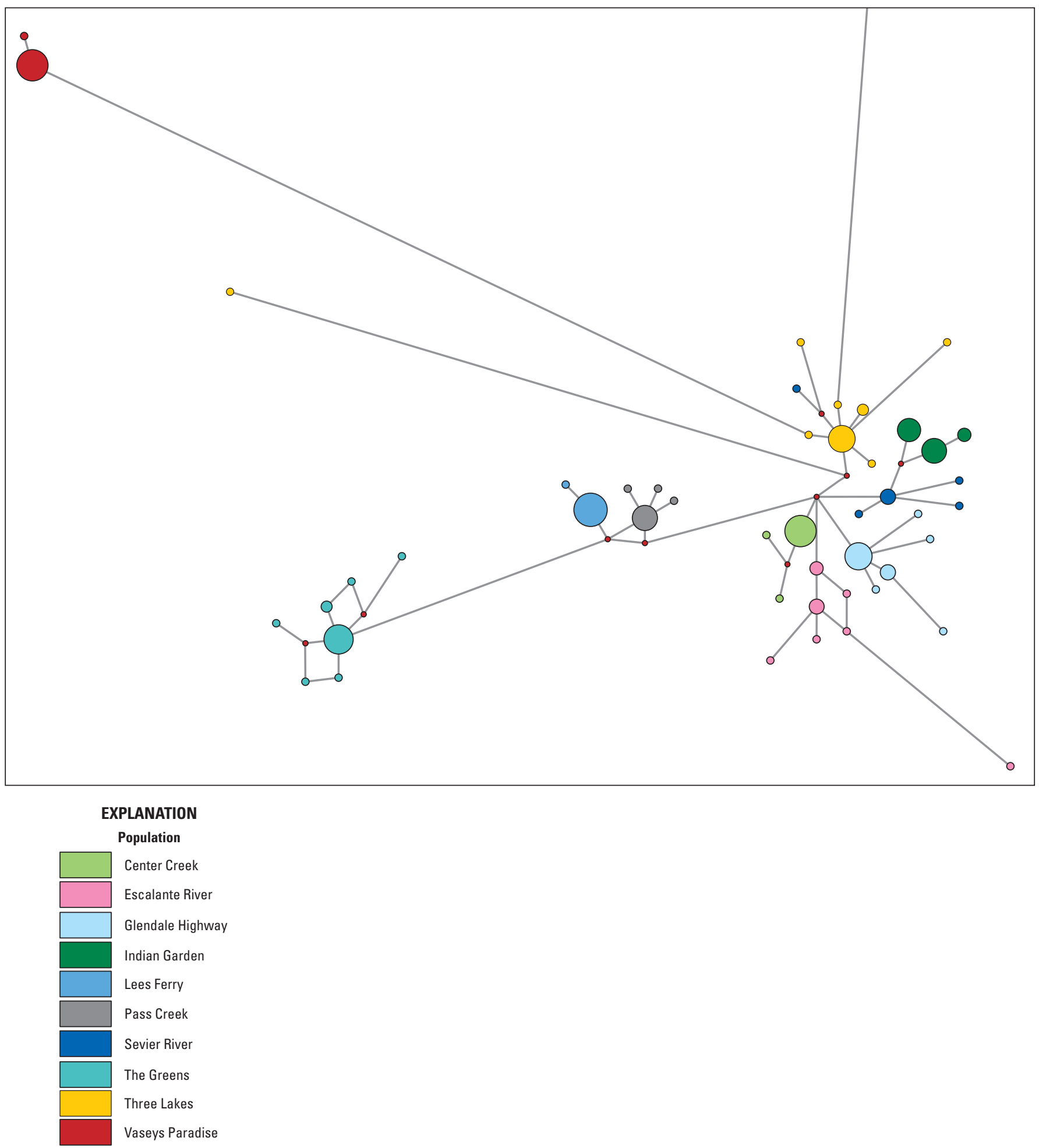

Figure 9.-Continued 


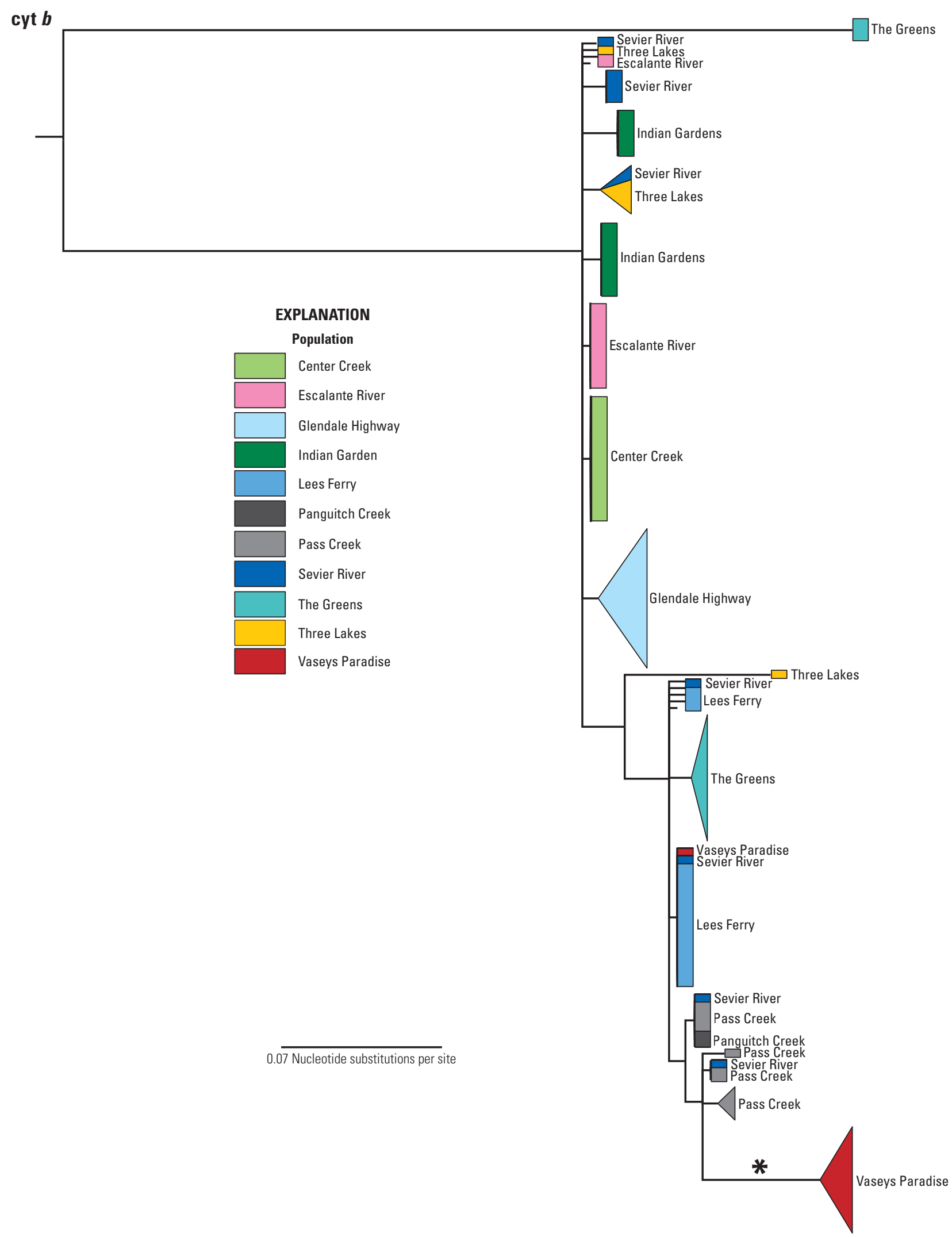

Figure 10. Bayesian 50-percent majority rule consensus tree diagram showing mitochondrial cytochrome $b$ gene (cyt $b$ ) dataset analyzed for Oxyloma populations sampled. The Panguitch Creek population is not included in the tree. Asterisk indicates wellsupported nodes (Bayesian posterior probability greater than 90 percent). The height of a rectangle or triangle indicates the relative number of individuals represented by the sample (larger height indicates more individuals), and the width of a rectangle or triangle indicates the relative evolutionary divergence (larger width indicates more divergence). 
cyt $b$

cyt $b$ Partial

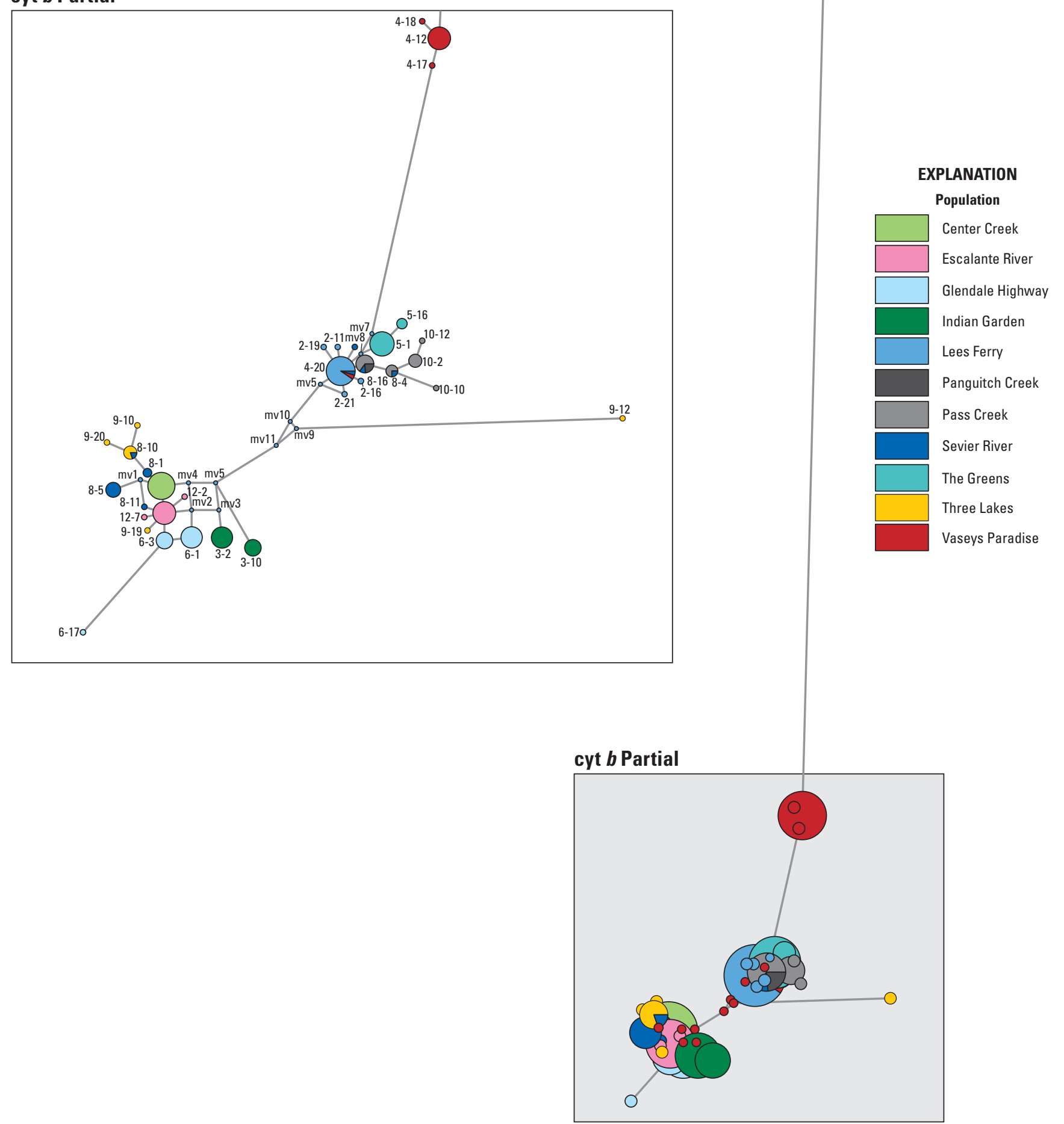

Figure 11. Median-joining haplotype network diagram showing mitochondrial cytochrome $b$ gene (cyt $b$ ) dataset analyzed for Oxyloma populations sampled. Cyt $b$ partial (in the box) represents an enlargement of the lower part of the complete network. Color codes represent the different populations and are the same as in the cyt $b$ Bayesian tree (fig. 10). The size of each circle is proportional to the number of individuals containing each haplotype, respectively. Branch lengths are proportional to mutational steps, and the shortest branch is one step. 
Table 12. Pairwise distance matrices for mitochondrial DNA datasets for Oxyloma populations from Arizona and Utah.

[Upper matrix is the complete concatenated dataset of the cytochrome b gene (cyt b) and cytochrome oxidase subunit I gene (COI) for a total of 876 base pairs. Two genetic distance measures are included; $\mathrm{F}_{\mathrm{ST}}$ (Fixation Index for subpopulation relative to the total combined population) is below the diagonal, Dxy (corrected average genetic distance between two populations, $\mathrm{x}$ and $\mathrm{y}$ ) is above the diagonal. Lower matrix is the same as the upper matrix, except without sample outliers 5_04, 5_19, and 5_23 from The Greens population. A bbreviations: n, number of individuals per population; PasCrk, Pass Creek; ER, Escalante River; LF, Lees Ferry; IG, Indian Garden; VP, Vaseys Paradise; Greens, The Greens; GHwy, Glendale Highway; CCrk, Center Creek; SR, Sevier River; 3L, Three Lakes; -, no data]

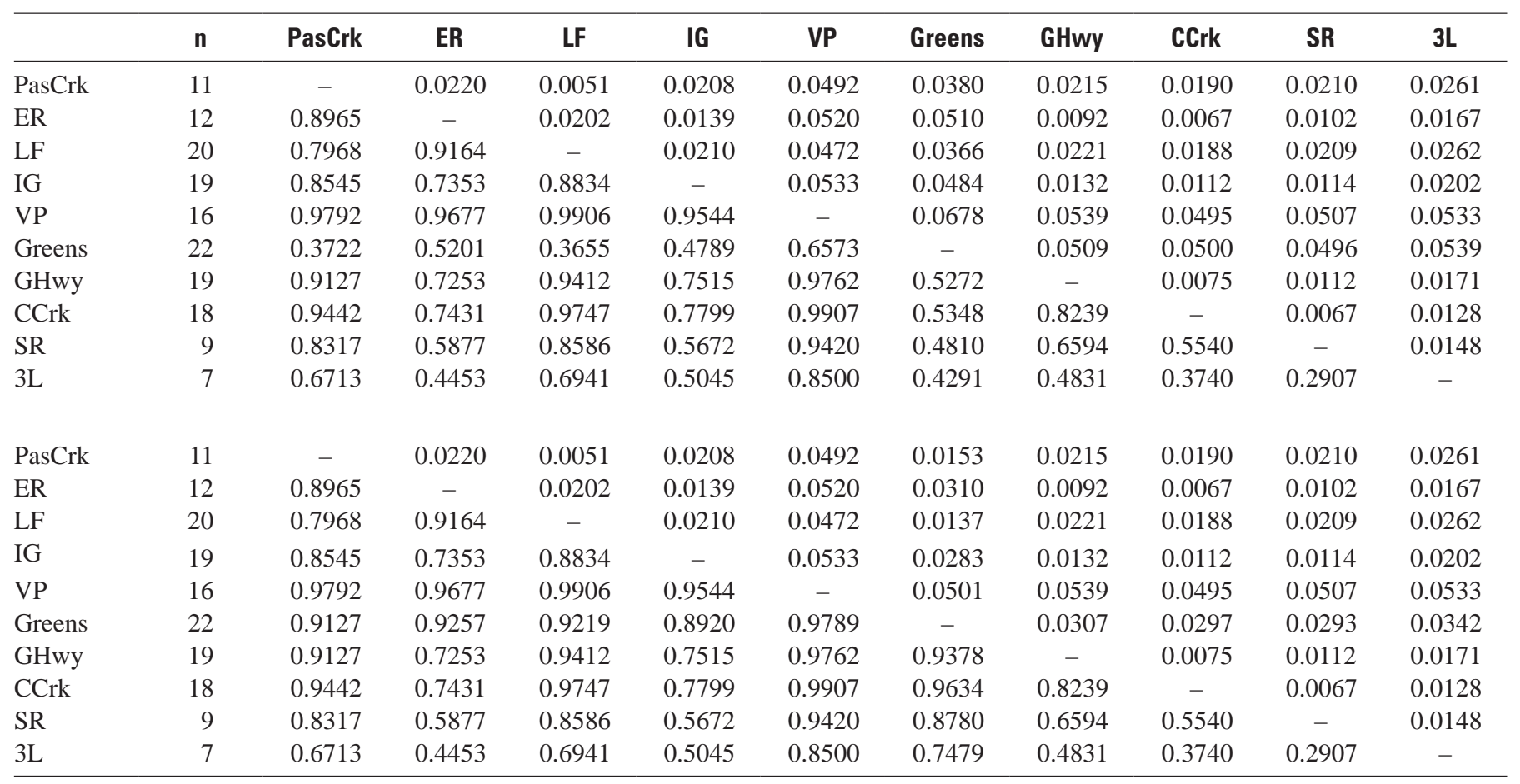


Results

mtconcat

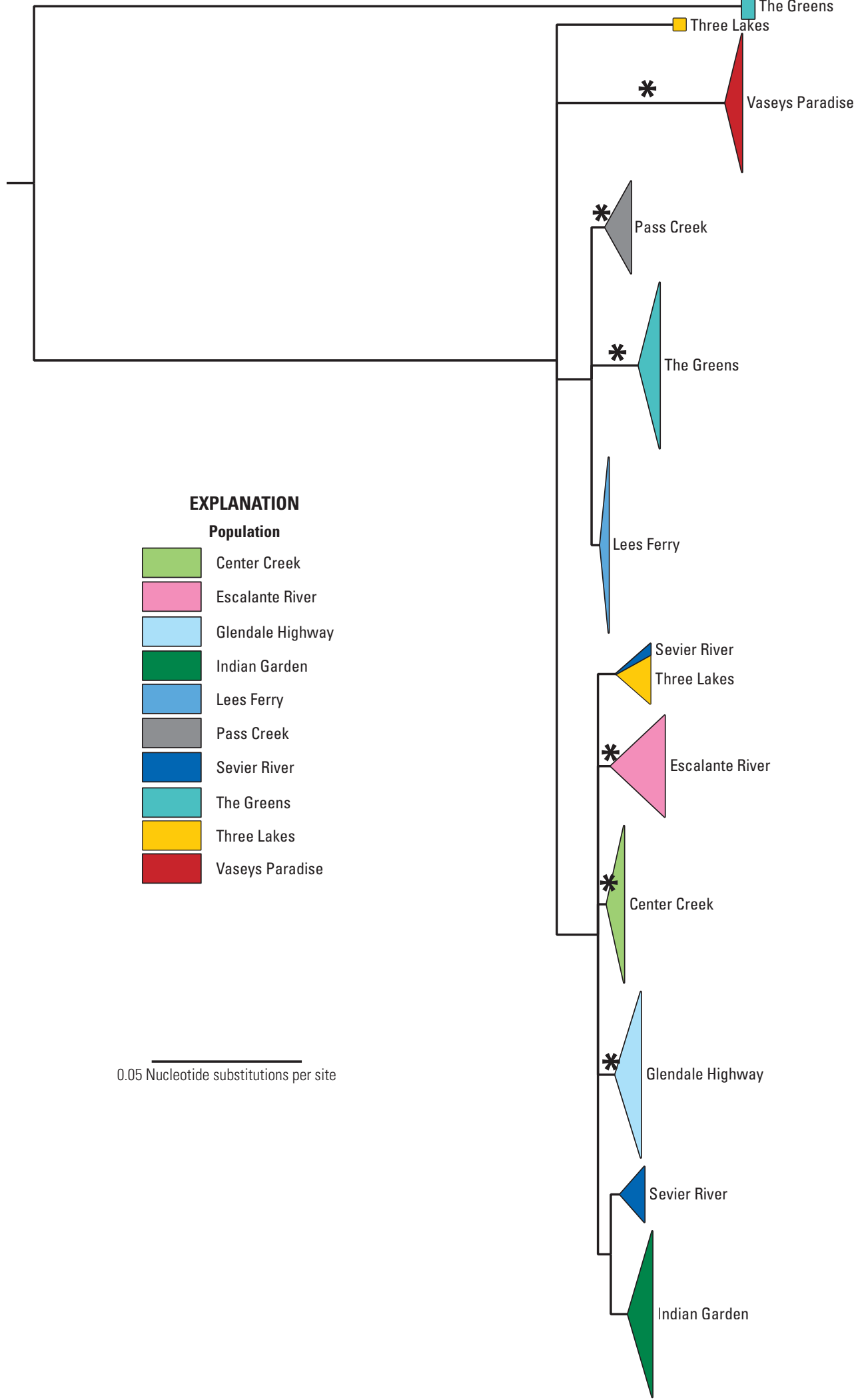

Figure 12. Bayesian 50-percent majority rule consensus tree diagram showing concatenated mitochondrial DNA dataset (mtconcat) including the cytochrome oxidase subunit I (COI) and cytochrome $b$ (cyt $b$ ) genes analyzed for Oxyloma populations sampled. The Panguitch Creek population is not included in the tree. Asterisks indicate well-supported nodes (Bayesian posterior probability greater than 90 percent). The height of a rectangle or triangle indicates the relative number of individuals represented by the sample (larger height means more individuals), and the width of a rectangle or triangle indicates the relative evolutionary divergence (larger width means more divergence). 
mtconcat

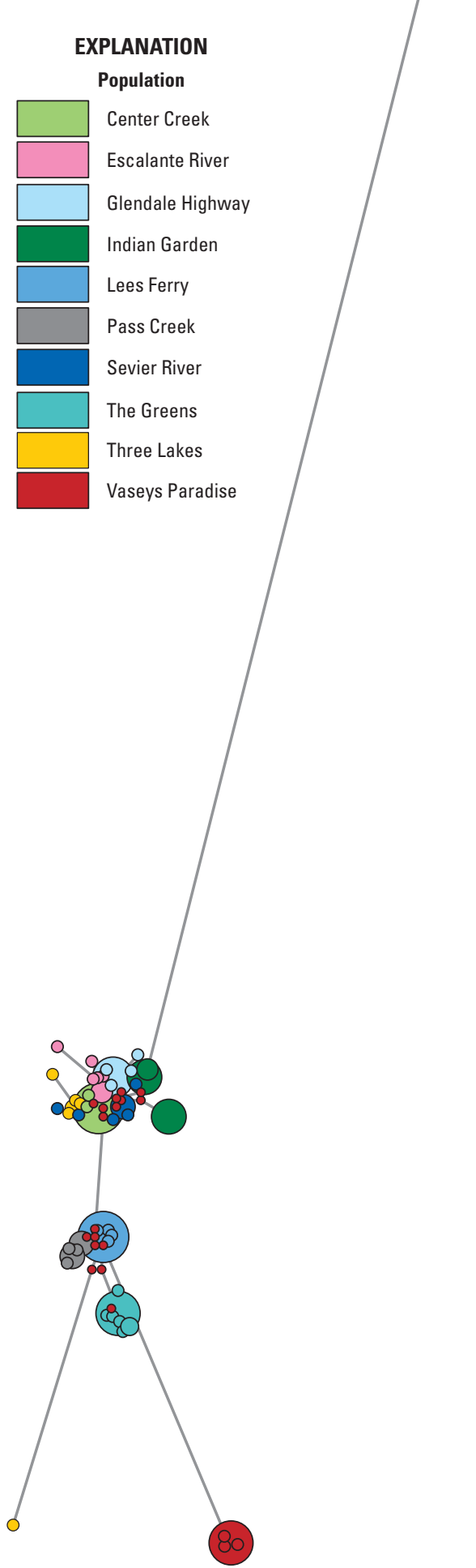

Single Copy

AMOVA results for the 4 nuclear loci showed that most of the observed variation exists among populations (greater than 67 to 97 percent, table 8). Pairwise $\mathrm{F}_{\mathrm{ST}}$ MDS plots (not shown) revealed no consistent population groups. The Lees Ferry, Glendale Highway and Escalante River populations showed slight deviations from the distribution of the other populations at most loci.

For the nuclear, single-copy loci, a Mantel test comparing pairwise genetic distance values (estimated using $\mathrm{F}_{\mathrm{ST}}$ ) with geographic distance (kilometers) between populations revealed a slight positive correlation between genetic and geographic distance for S7 and $458\left(\mathrm{r}^{2}\right.$ greater than or equal to 0.07 and $\mathrm{r}^{2}$ greater than or equal to 0.19 , respectively; table 8 ). Therefore, only 7 percent or less (and 19 percent or less for region 458) of the genetic distance variance could be explained by geographic distance. The $\mathrm{S} 7$ fragment was 485 bp long and included 48 variable sites, 33 parsimony informative sites, and two indels (1 and 9 bp in length). The S7 dataset included 43 haplotypes detected among 222 individuals that successfully amplified from among all populations. This made S7 the locus with the largest and most representative dataset.

Signals for population expansion with statistically significant negative values for Tajima's D (table 9), Fu's Fs $(\underline{\text { table 10 }}$ ) and statistically significant small positive values for the Roza's $R_{2}$ (table 11) were seen in Glendale Highway, Center Creek, Three Lakes, Panguitch Creek and Escalante River populations. The Vaseys Paradise population deviated from the multimodal curve of a stable population at the S7 locus.

Phylogenetic trees were generated using Neighbor Joining (NJ), Maximum Parsimony (MP) and Bayesian algorithms. The trees had similar features so only the Bayesian tree was shown (fig. 14). Ten samples from Vaseys Paradise and 3 samples from Elves Chasm shared 1 haplotype with Panguitch Creek, Sevier River, Pass Creek, Three Lakes and The Greens. This haplotype was the most commonly found haplotype in the dataset. Lees Ferry samples shared their haplotype with Escalante River samples, and Center Creek samples shared their haplotype with Three Lakes, Sevier River and Pass Creek. Samples from The Greens formed three major groups, which were distributed in different areas of the trees. The only monophyletic population was Glendale Highway. It is noteworthy that one shared haplotype from The Greens (including 24 single haplotypes) is equally distant from all other groups in the trees, with a branch length that is the largest observed in the S7 analyses.

The haplotype network (fig. 15) showed some geographic mixing and some discrete geographic units. The network structure corresponded less to populations or geographic units than was observed for the mitochondrial loci networks.

Figure 13. Median-joining haplotype network drawing showing concatenated mitochondrial DNA dataset (mtconcat) including the cytochrome oxidase subunit I (COI) and cytochrome $b$ (cyt $b$ ) genes analyzed for Oxyloma populations sampled. Color codes represent the different populations and are the same as in the mtconcat Bayesian tree (fig. 12). The size of each circle is proportional to the number of individuals containing each haplotype, respectively. Branch lengths are proportional to mutational steps, and the shortest branch is one step. 
S7

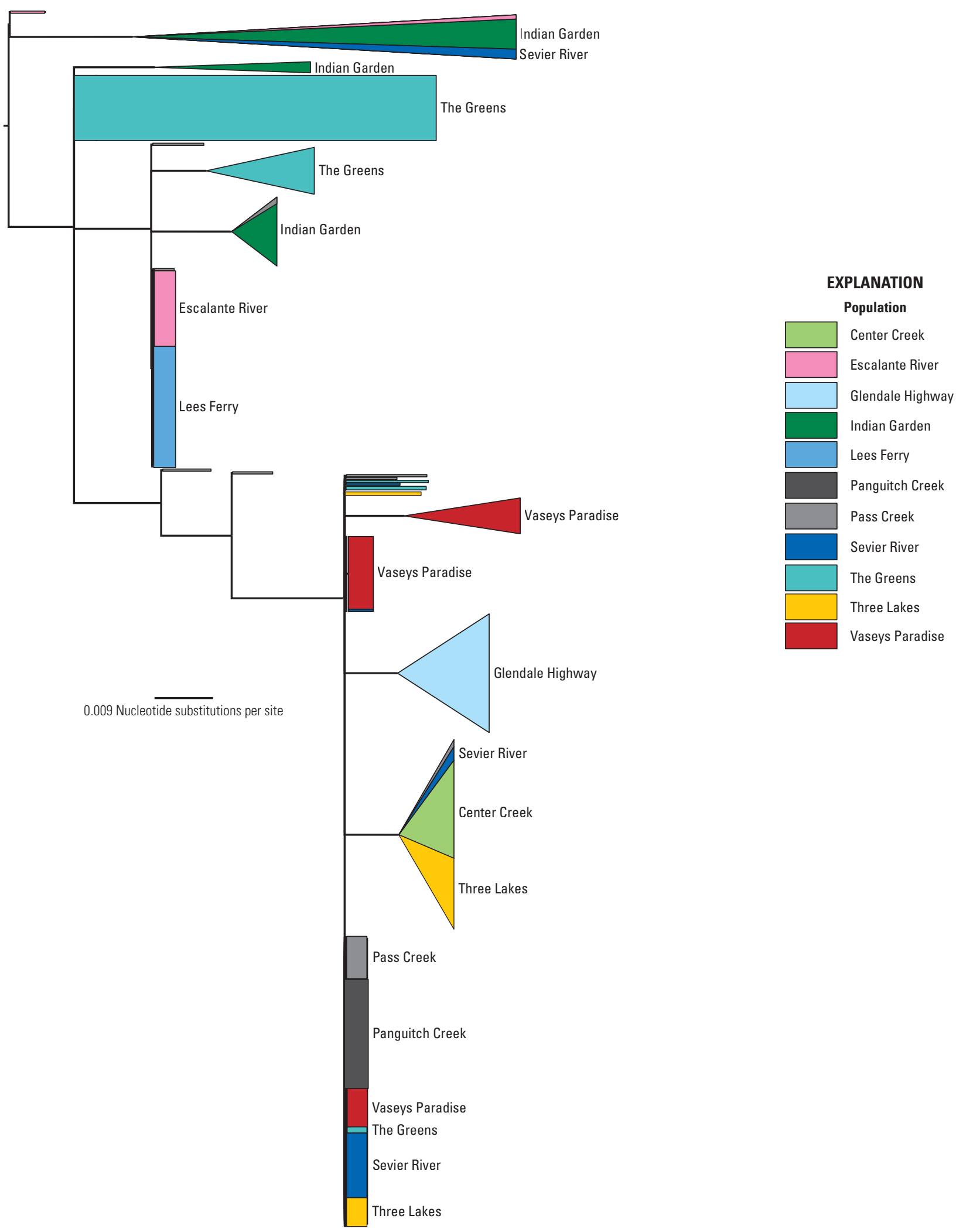

Figure 14. Bayesian 50-percent majority rule consensus tree diagram showing ribosomal gene introns S7-1 and S7-2 (S7) dataset analyzed for Oxyloma populations sampled. The height of a rectangle or triangle indicates the relative number of individuals represented by the sample (larger height indicates more individuals), and the width of a rectangle or triangle indicates the relative evolutionary divergence (larger width indicates more divergence). 


\section{S7}

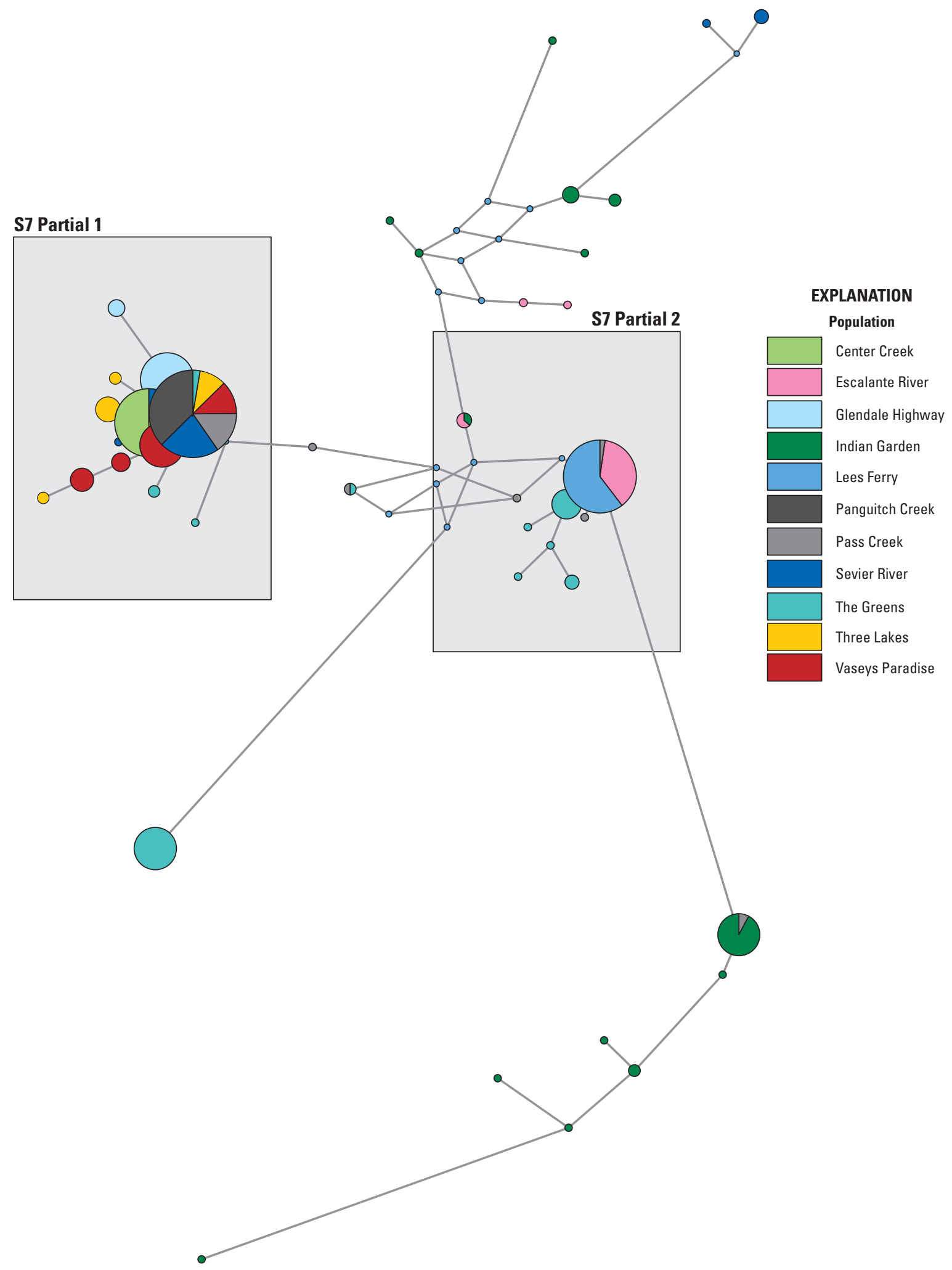

Figure 15. Median joining haplotype network diagram showing ribosomal gene introns S7-1 and S7-2 (S7) dataset analyzed for Oxyloma populations sampled. S7 partial 1 and 2 (below the main network) represent magnified parts of the complete network. Color codes represent the different populations and are the same as in the S7 Bayesian tree (fig. 14). The size of each circle is proportional to the number of individuals containing each haplotype, respectively. Branch lengths are proportional to mutational steps, and the shortest branch is one step. 


\section{S7 Partial 1}

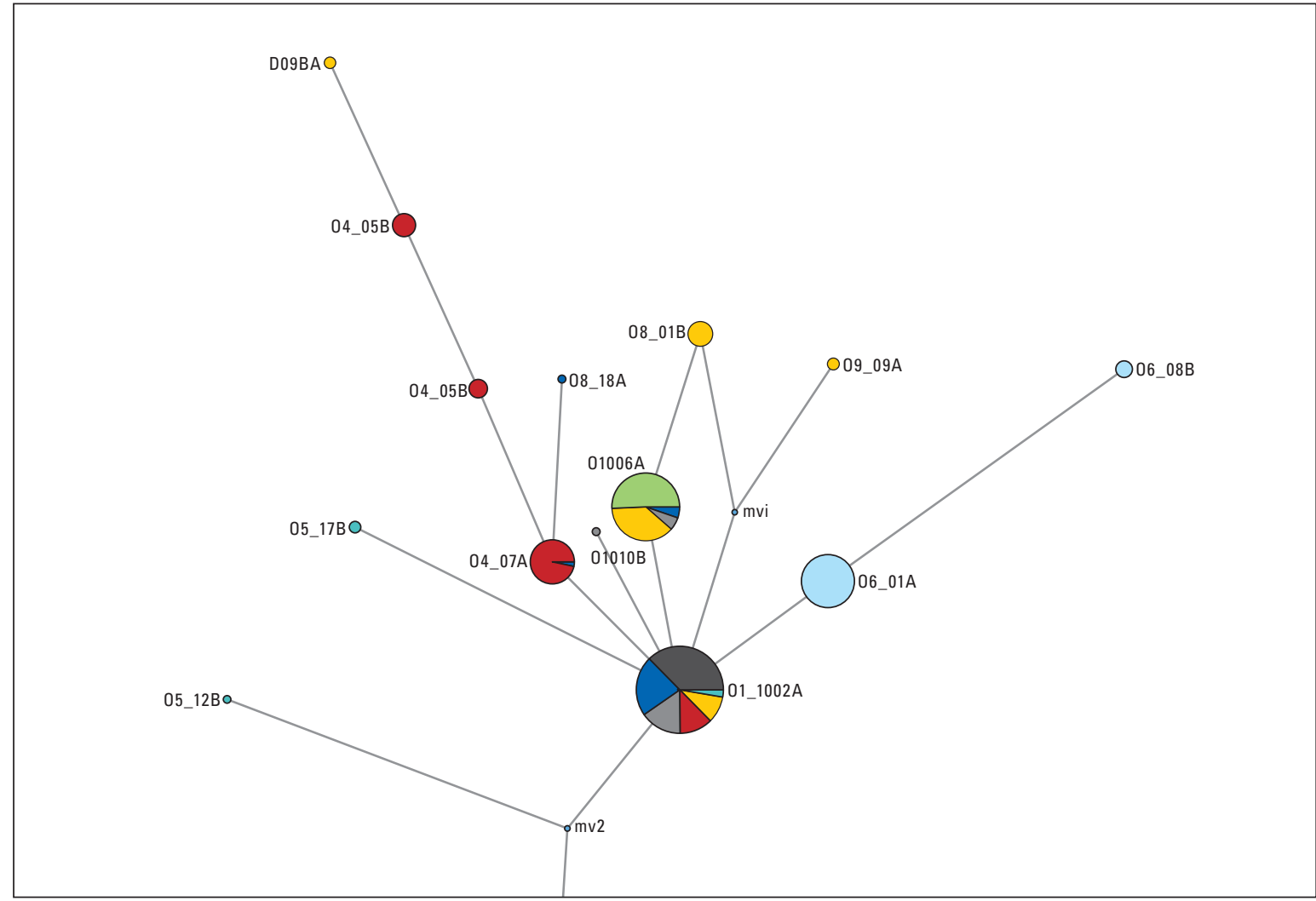

\section{S7 Partial 2}

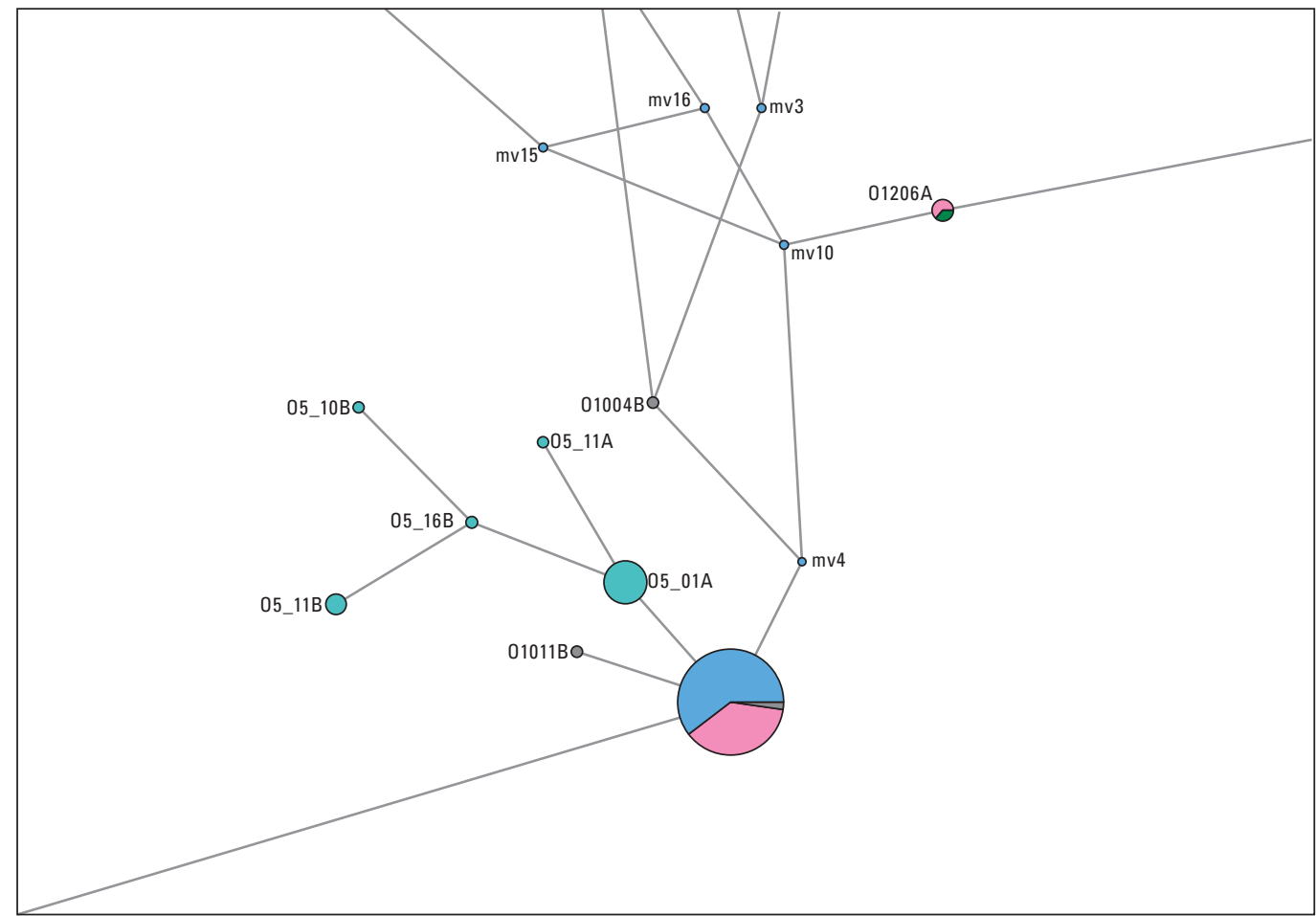

EXPLANATION

Population

$\square$ Center Creek

Escalante River

Glendale Highway

Indian Garden

Lees Ferry

Panguitch Creek

Pass Creek

Sevier River

The Greens

Three Lakes

Vaseys Paradise

Figure 15.-Continued 
ITS had a length of 616 bp including 51 variable sites, 33 parsimony informative sites, and one indel. The indel was extensive in size, with a minimum size of $142 \mathrm{bp}$, and had variable sizes within and among individuals, occurring in 11 different size states ranging from 142 to $387 \mathrm{bp}$. This and the discovery of paralogous amplicons for ITS in other studies made this marker questionable, unless techniques such as cloning all alleles prior to sequencing are applied to ensure that compared sequences are orthologous (Rosselló and others, 2007). Therefore, ITS was excluded from the concatenated dataset. ITS sequences represented 126 samples with some populations such as Vaseys Paradise, Lees Ferry and Glendale Highway, producing many sequences, and other populations producing none (Sevier River), or very few sequences (The Greens, Center Creek, Pass Creek and Indian Garden) (table 2). The 126 samples represented 22 different haplotypes.

The different phylogenetic analysis algorithms used for ITS sequences (NJ, MP, and Bayesian) largely agree for this sample size and character number reduced dataset. The Bayesian tree is shown in figure 16. Population-based structure was apparent. The only population that was not grouped by geography, but instead was scattered throughout the trees, was Pass Creek. Because of limited variability in the dataset, a haplotype network was not calculated for ITS sequences.

The 356 locus sequence was 192 bp long and included 25 variable and 15 parsimony informative sites. Two indels were observed, one of which was between 1 and11 nucleotides long (occurring in 7 different length states). A total of 138 sequences were obtained for the 356 locus. These covered all populations with the exception of Indian Garden. Only three and five sequences were obtained from Pass and Panguitch Creeks, respectively.

The Bayesian phylogenetic tree for the 356 locus (fig. 17) showed many unresolved relationships, with only one group supported by bootstrap values and Bayesian posterior probabilities. This group contained 18 haplotypes from Vaseys Paradise, all 28 haplotypes from Three Lakes, and 4 haplotypes from Sevier River. Haplotypes from the same populations mostly appeared in different parts of the tree. Only Lees Ferry samples showed one haplotype that was not shared with other populations. NJ and MP trees showed similar topology to the Bayesian tree and are not shown. The haplotype network shows the same pattern as the phylogenetic trees (fig. 18).

The 458 locus produced a sequence of 525 bp with 36 variable sites, 32 parsimony informative sites, and five indels (one with two length states). A total of 109 samples that successfully amplified were sequenced and produced 26 different haplotypes. None of the samples from the Three Lakes population produced sequences. From Pass Creek, only two samples amplified, and from Center Creek, only four samples could be sequenced.

NJ, MP and Bayesian phylogenetic trees were generated and showed similar topology, so only the Bayesian tree is shown (fig. 19). Lees Ferry haplotypes formed the only monophyletic group. All samples from Vaseys Paradise, The
Greens, Indian Garden, and Glendale Highway had only one haplotype. Of these, Vaseys Paradise and The Greens shared the same haplotype, and Indian Garden and Glendale Highway shared the same haplotype. Other populations, such as Panguitch Creek and Sevier River, exhibited a number of different haplotypes, which were distributed over larger areas of the trees. The haplotype network for the 458 locus was consistent with the phylogenetic trees (fig. 20).

We concatenated the sequences of S7, 356 and 458 for all individuals, which produced sequences for all three loci. The fourth locus ITS was not included for reasons of DNA sequence quality mentioned in Single Copy of the section Results. The concatenated dataset resulted in only 74 individuals; Indian Garden, Three Lakes, and Pass Creek samples were not included. The dataset included 92 variable and 86 parsimony informative sites in 52 haplotypes.

Phylogenetic analysis, using NJ, MP, and Bayesian algorithms for the concatenated nuclear DNA dataset, showed population structure with a number of exceptions, such as the Panguitch Creek haplotypes, one Escalante haplotype, or two Sevier River haplotypes (tree not shown).

The haplotype network for the concatenated nuclear DNA dataset agreed largely with the phylogenetic tree, with the exception that the Glendale Highway population haplotypes were positioned within the Vaseys Paradise-Elves Chasm haplotypes. Furthermore, all Escalante River haplotypes clustered together with a monophyletic origin (network not shown).

Overall, phylogenetic patterns observed in the nuclear gene trees were not consistent with each other or with the patterns observed for the two mitochondrial loci. No population was monophyletic in all analyses and all loci. Two populations, Lees Ferry and Glendale Highway, showed the lowest amount of within-population variability. The Sevier River population showed the widest phylogenetic diversity across the phylogenetic analyses and haplotype networks.

\section{Microsatellite (Single Locus)}

One microsatellite locus, KS6511, was amplified across all sampled populations. KS6511 is a GA dinucleotide repeat with a complex structure of (GA)8...(GA)7 in the sequenced copy. The alleles ranged from 10 to 53 repeats, but because of the complex structure, allele numbering did not strictly correspond to the number of repeats. The Greens, Three Lakes, and to some degree Panguitch Creek populations showed the complete allele diversity possible with the marker. Four populations were monomorphic (homozygous): Lees Ferry, Indian Garden, Center Creek, and Escanante River. All other populations exhibited fewer alleles relative to The Greens and Three Lakes populations (fig. 21). Figure 21 also included samples from the northern United States and Canada, which may have represented source populations for long-distance migrants. The alleles observed in the Arizona and Utah study area appeared to be a subset of the alleles present in Oxyloma from the northern areas. 


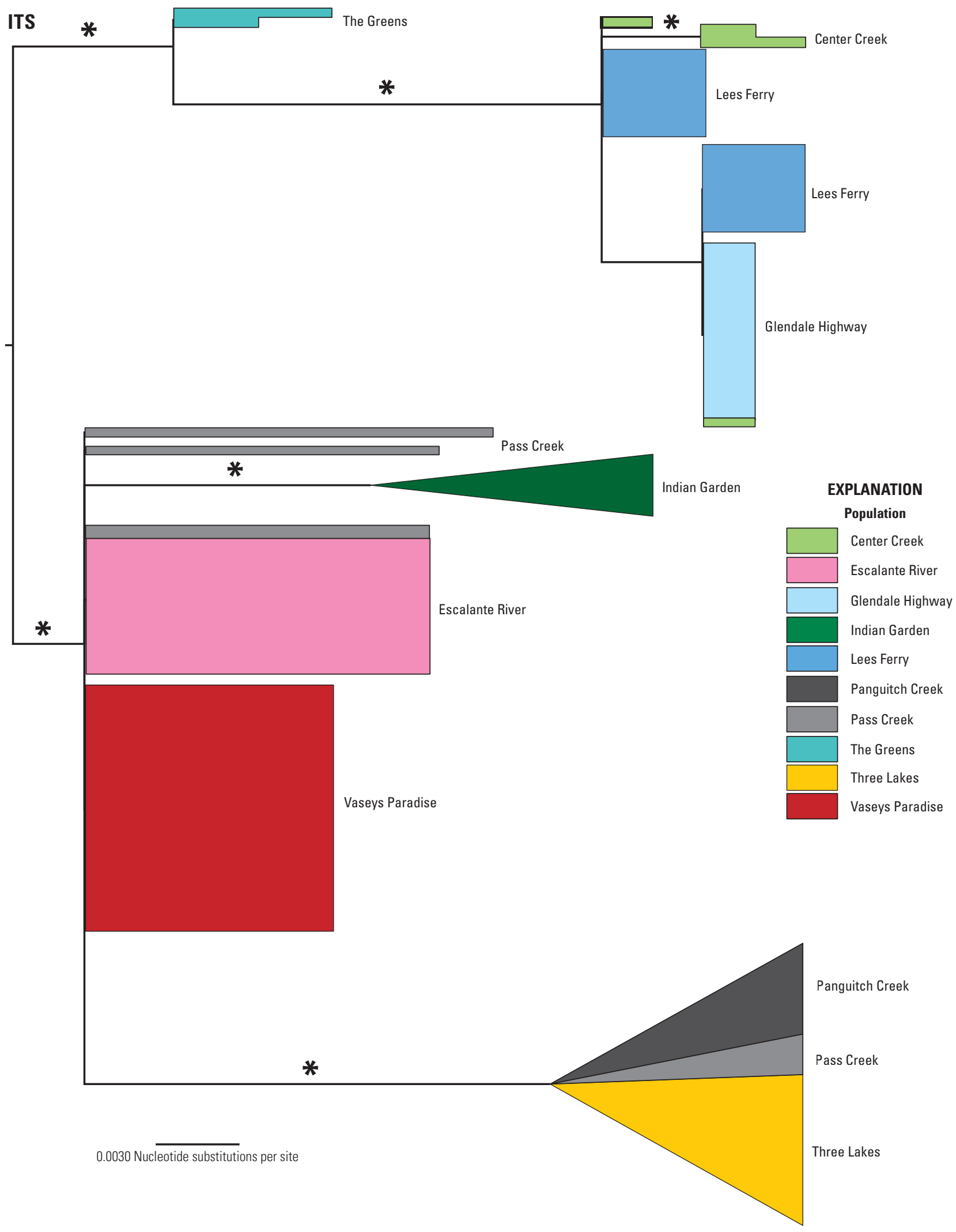

Figure 16. Bayesian 50-percent majority rule consensus tree diagram of the ribosomal DNA first and second internal transcribed spacer (ITS) dataset analyzed for Oxyloma populations sampled. The Sevier River population is not included in the tree. Asterisks indicate well-supported nodes (Bayesian posterior probability greater than 90 percent). The height of a rectangle or triangle indicates the relative number of individuals represented by the sample (larger height means more individuals), and the width of a rectangle or triangle indicates the relative evolutionary divergence (larger width means more divergence). 
356

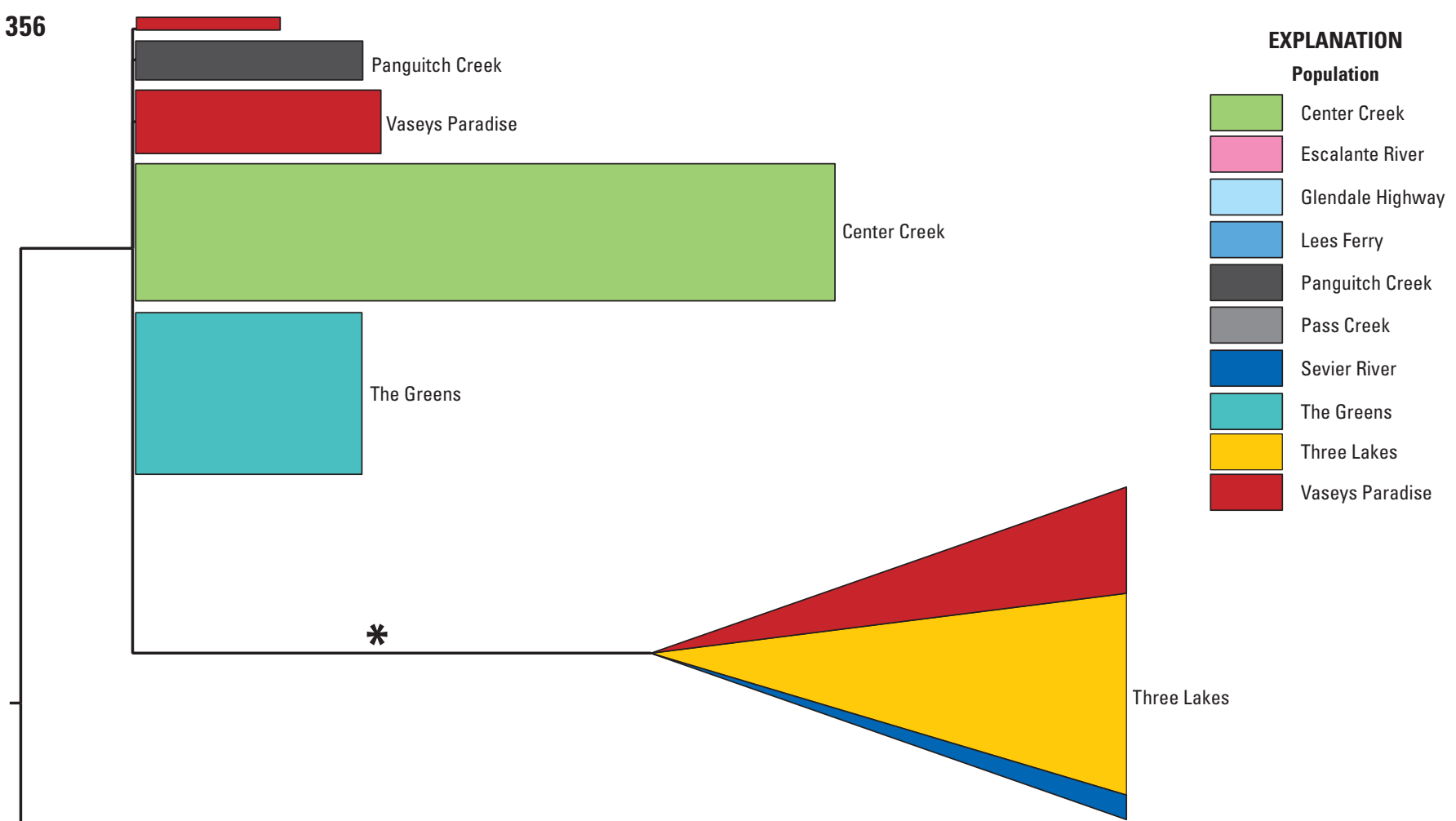

Center Creek

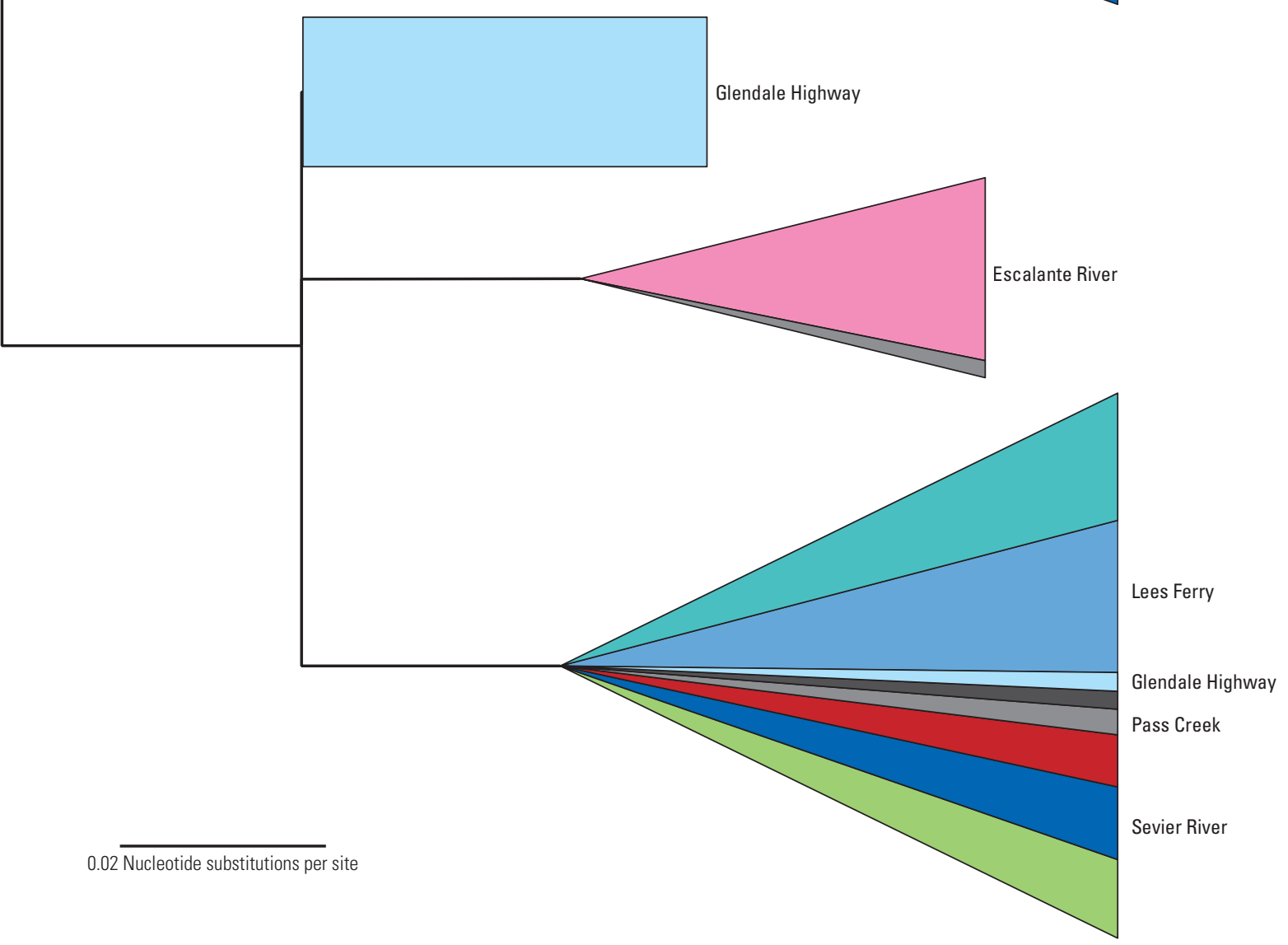

Figure 17. Bayesian 50-percent majority rule consensus tree diagram showing random ambersnail nuclear clone 356 (356) dataset analyzed for Oxyloma populations sampled. The Indian Garden population is not included in the tree. Asterisks indicate well-supported nodes (Bayesian posterior probability greater than 90 percent). The height of a rectangle or triangle indicates the relative number of individuals represented by the sample (larger height means more individuals), and the width of a rectangle or triangle indicates the relative evolutionary divergence (larger width means more divergence). 
356

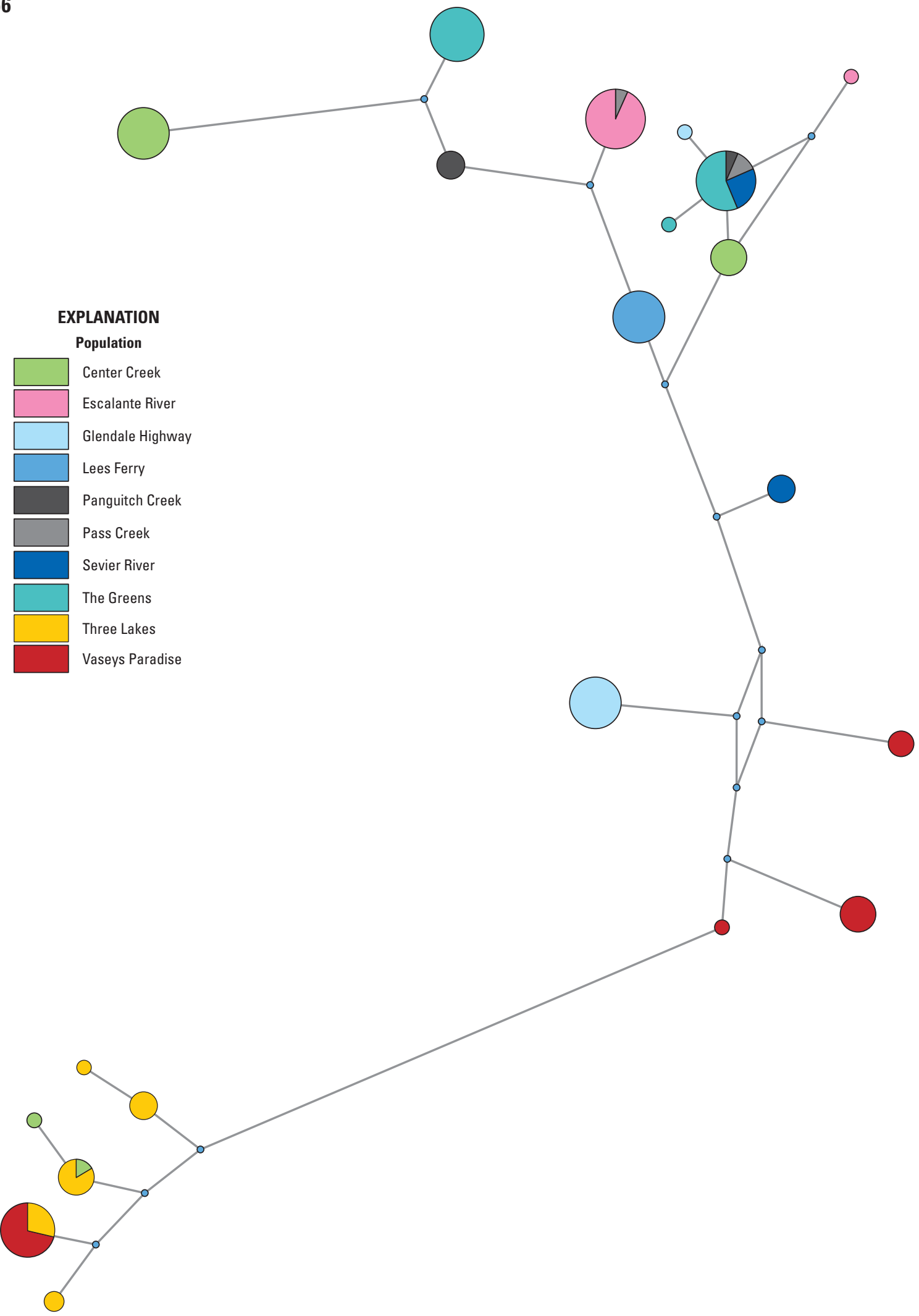

Figure 18. Median-joining haplotype network diagram showing random ambersnail nuclear clone 356 (356) dataset analyzed for Oxyloma populations sampled. Color codes represent the different populations and are the same as in the 356 Bayesian tree (fig. 17). The size of each circle is proportional to the number of individuals containing each haplotype, respectively. Branch lengths are proportional to mutational steps, and the shortest branch is one step. 
458

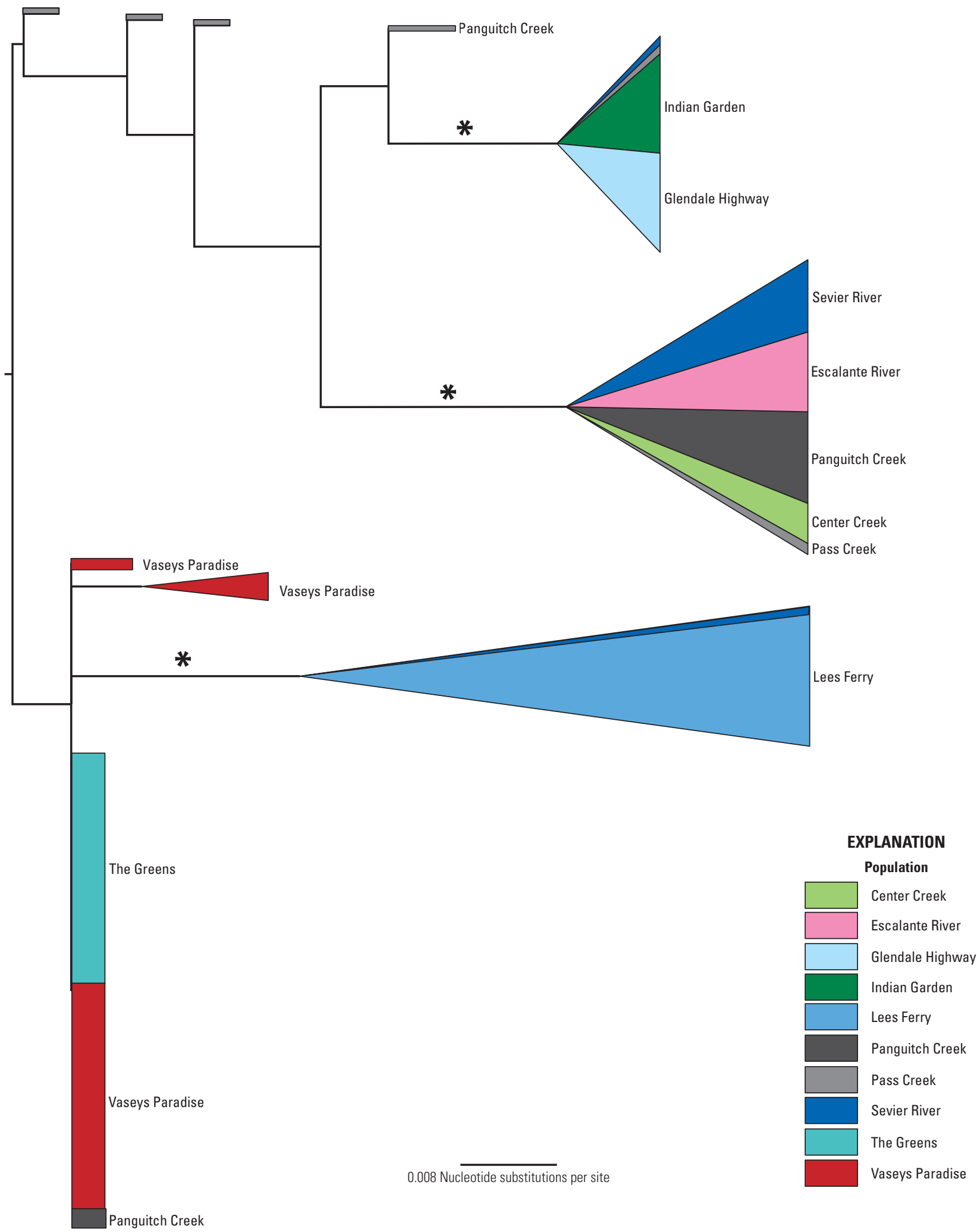

Figure 19. Bayesian 50-percent majority rule consensus tree diagram showing random ambersnail nuclear clone 458 (458) dataset analyzed for Oxyloma populations sampled. The Three Lakes population is not included in the tree. Asterisks indicate well-supported nodes (Bayesian posterior probability greater than 90 percent). The height of a rectangle or triangle indicates the relative number of individuals represented by the sample (larger height means more individuals), and the width of a rectangle or triangle indicates the relative evolutionary divergence (larger width means more divergence). 


\section{8}

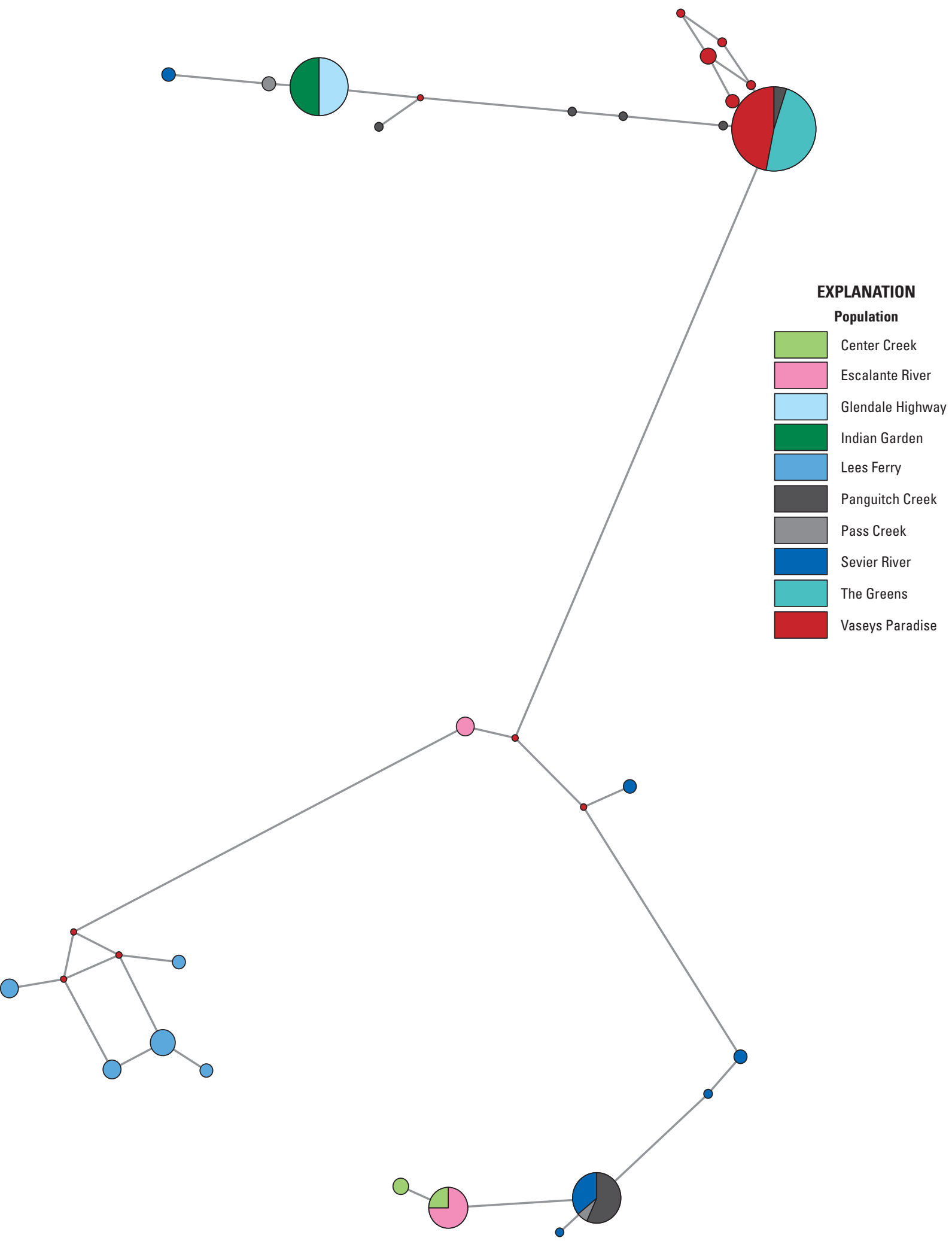

Figure 20. Median-joining haplotype network diagram showing random ambersnail nuclear clone 458 (458) dataset analyzed for Oxyloma populations sampled. Color codes represent the different populations and are the same as in the 458 Bayesian tree (fig. 19). The size of each circle is proportional to the number of individuals containing each haplotype, respectively. Branch lengths are proportional to mutational steps, and the shortest branch is one step. 


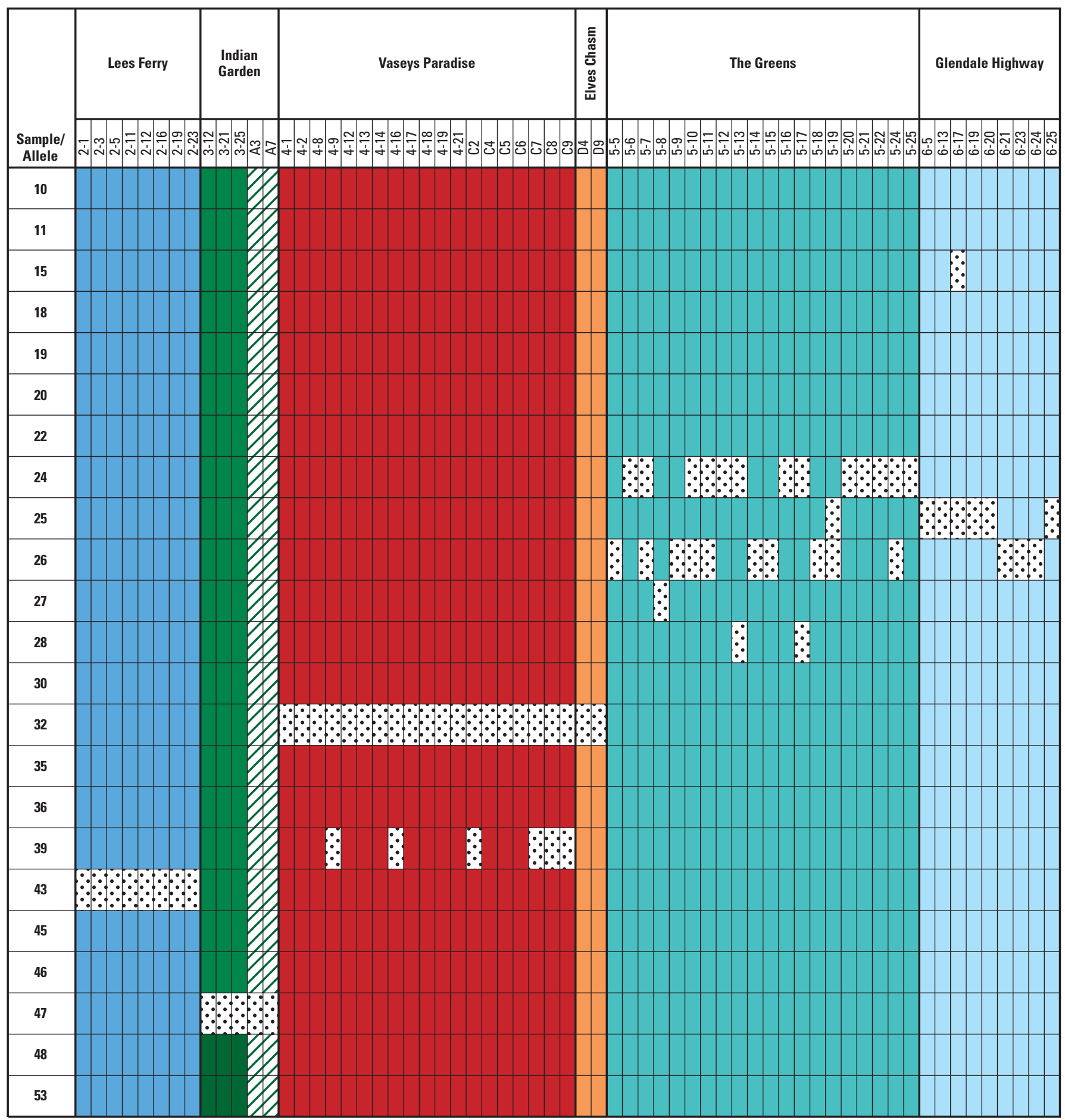

Figure 21. Nuclear microsatellite alleles present in each individual, indicated by cells with allele sizes listed across columns and individuals listed down rows. Oxyloma populations are labeled and color coded with the same colors used in the phylogenetic trees and map for ease of viewing population differences. Alleles for an individual are indicated as white stippled cells at the appropriate allele size. A group of samples from north of the study area also is shown. 


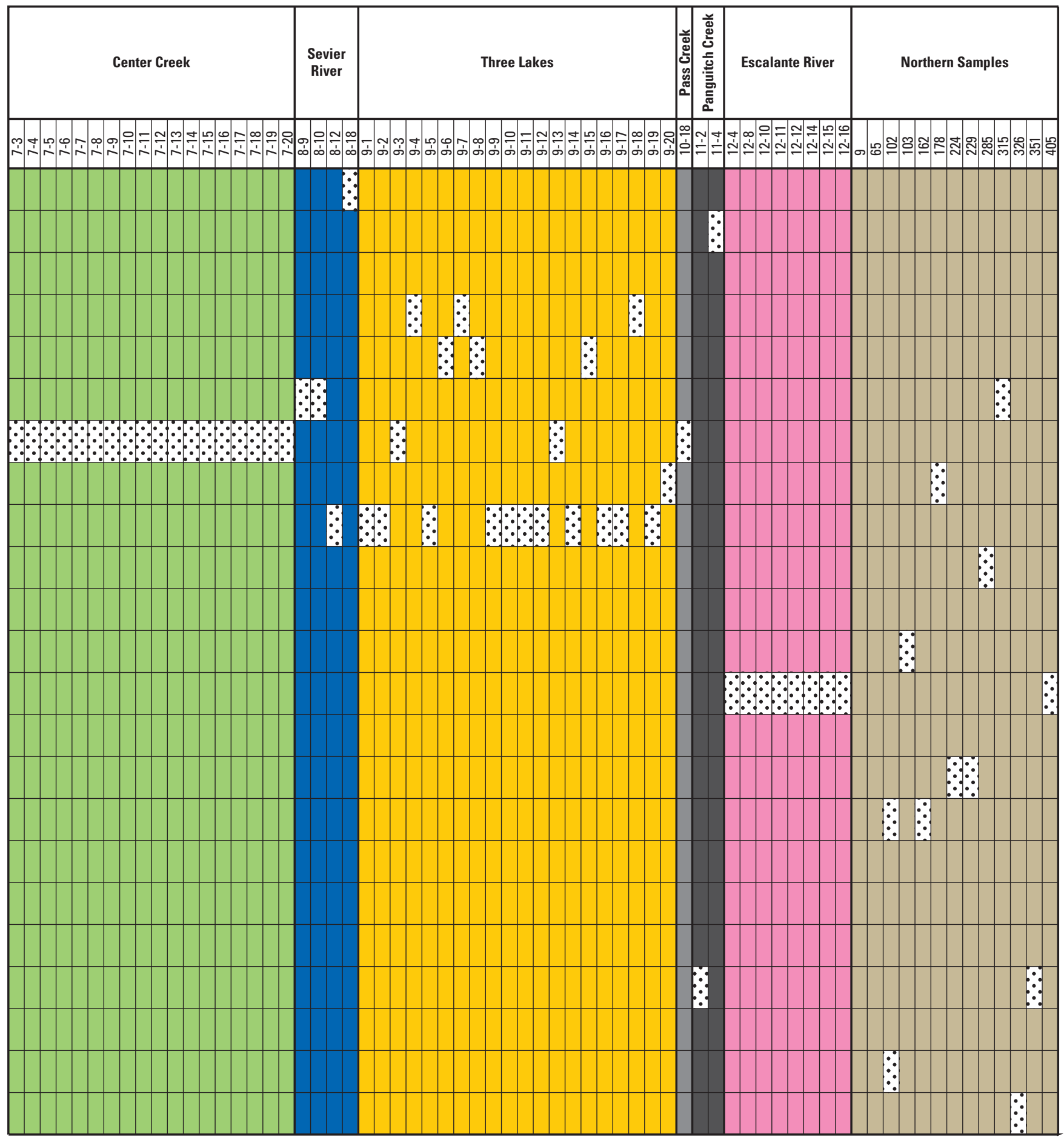

Figure 21.-Continued 


\section{AFLP (Multilocus)}

The UPGMA tree generated from the AFLP data generally indicated that most sampling locations were distinct from one another (igg. 22).

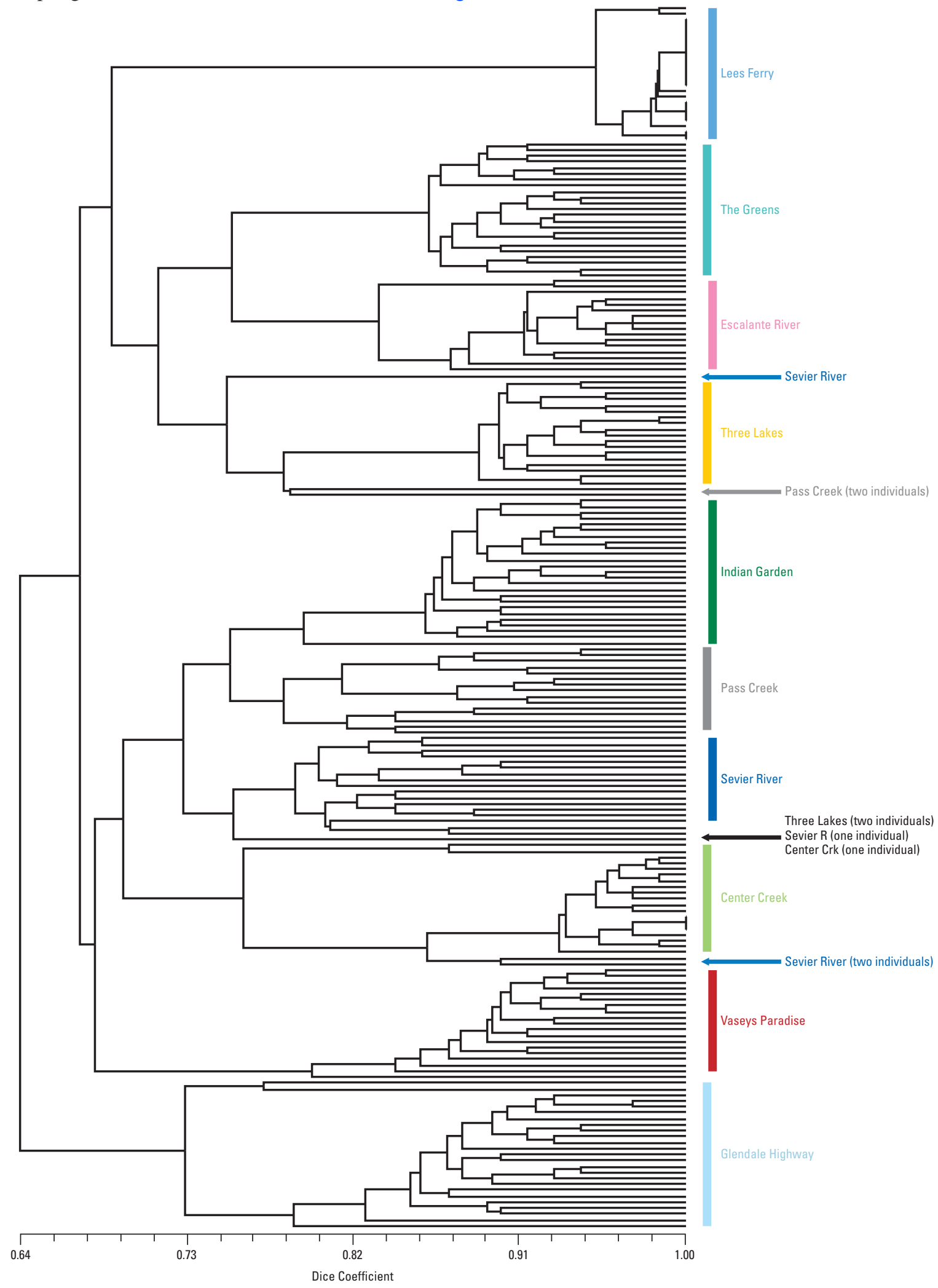

Figure 22. Unweighted Pair Group Method with Arithmetic mean (UPGMA) tree diagram showing Amplified Fragment Length Polymorphism (AFLP) data analyzed for Oxyloma populations sampled. The Panguitch Creek, Utah, population is not included in the tree. 
However, two lines of evidence suggest that it may not be appropriate to consider each population as "genetically distinct.” First, although uncommon, multiple analyzed individuals did not directly cluster with other individuals from their shared sampling location. Second, there was often relatively large variation in branch lengths among individuals forming the distinct clusters. Together, these data suggested that in some instances, the genetic ancestry of some individuals may be, in part, derived from other source populations.

Analyses using STRUCTURE confirmed the general pattern observed in the UPGMA tree. Rather than identifying $\mathrm{K}=10$ genetic clusters (the number of sampled locations due to the removal of the Panguitch population from the analysis), STRUCTURE suggested that $\mathrm{K}=9$ was a more likely value (fig. 23). This was mainly because STRUCTURE tended to define the loosely-differentiated Pass Creek and Indian Garden populations as being from the same cluster, as indicated by the prevalence of shared pink coloration in the STRUCTURE output (fig. 23). The result of nine genetic clusters was consistent with the relatively weak differentiation of these two populations (Pass Creek and Indian Gardens) in the UPGMA tree (fig. 22). More importantly, the STRUCTURE analysis suggested the presence of diverse ancestry among analyzed individuals from several sampling locations (particularly Glendale Highway, Center Creek, Sevier River, Pass Creek, and Escalante River).

Figure 23. Results of a Bayesian STRUCTURE analysis of the Amplified Fragment Length Polymorphism (AFLP) data analyzed for Oxyloma populations sampled. The analysis suggested the presence of $\mathrm{K}=9$ genetic clusters of individuals, or 9 populations, from 11 sampled locations. Each individual from each sampling location is represented in columns along the horizontal axis. Each of the $\mathrm{K}=9$ detected clusters is indicated by a different color. The proportion of each individual's genome that is derived from each cluster is represented as a function of the height (vertical) of each colored sub-bar.

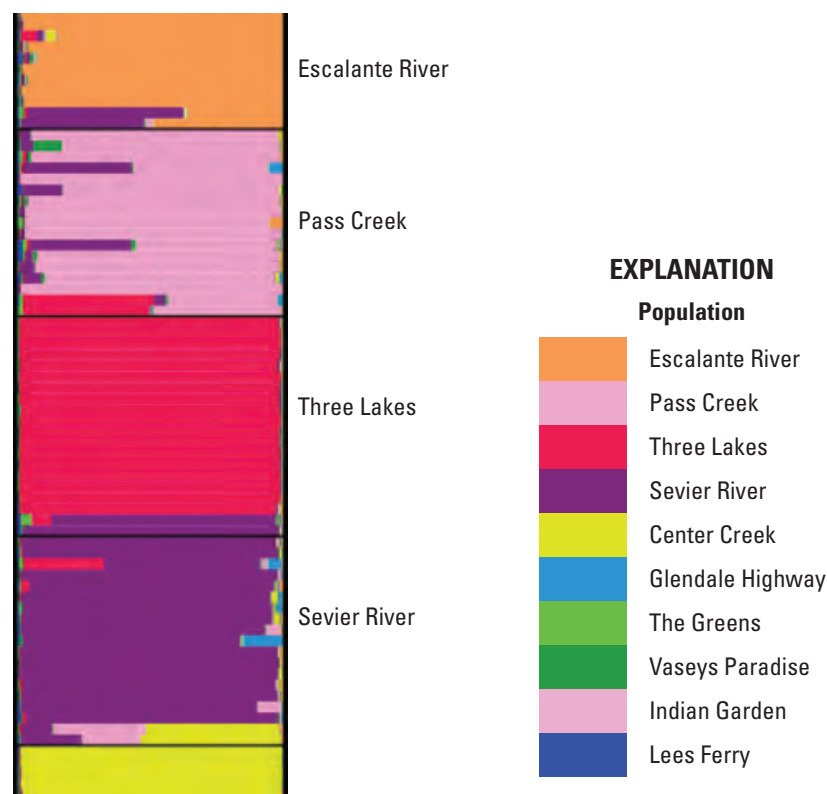

Note: This population color scheme does not match the other graphics 


\section{Discussion}

The data obtained for this study dramatically increased our understanding of Oxyloma, and more specifically, the taxonomic status of the federally endangered Kanab ambersnail. All analyses from this study, morphologic and genetic, supported the recognition of a single species of Oxyloma occurring in this study area. Some of the more high-resolution genetic data from the nuclear DNA (AFLP and microsatellite) indicated that population samples for this study were differentiated into distinct genetic groups. The significance of those groups was less obvious and will be discussed in the section Conservation Implications.

\section{Shell Morphology}

From the principal components analysis and the discriminant analysis, it was apparent that variation in shell morphology in the examined samples showed little geographic coherence. No meaningful combination of variables was effective at classifying more than about one-half of the analyzed specimens with respect to their samples of origin. Shell characters were poor predictors of population membership among these samples. The best characters were size-related. Size in molluscan populations and samples is well known to be affected by ontogeny, nutrition, local climate, and other secular factors (Goodfriend, 1986). The conclusion was that most of the variation within the system studied likely came from non-taxonomic, non-phylogenetic factors and represented an expected level of variability within one succineid species.

Discriminant analysis failed to assign the holotype of O. h. kanabense to its type population (The Greens) over three other options (Vaseys Paradise, Pass Creek, and Lees Ferry).

\footnotetext{
${ }^{7}$ The only other anatomical information on $O . h$. haydeni appears to be the drawings by Stevens and others (2000), consisting of a sketch of the talon, hermaphrodite duct, and (apparently) part of the ovotestis (upper right in figure), and one depicting part of the epiphallus, penial retractor muscle, and penis (apparently cut free from the penial sheath, which appears as a collar around its base). The figures are unlabeled. No comparison is made with 16 other specimens identified as "Oxyloma haydeni" (Stevens and others, 2000). The upper end of the penis bears a small, tubular appendix, like $O$. h. kanabense and many other Oxyloma, but no diagnostic details are presented.

8“Mantle over the lung not pigmented. Genitalia, Fig. 419A. The hermaphrodite duct is very large and swollen in specimens examined, and with the talon, is covered with a thin light gray membrane. The prostate gland is long. Penis short, somewhat swollen above, where it is abruptly bent, gives off a small, tapering appendix and the epiphallus, which makes about one spiral turn. (Fig. 419a). The vagina is nearly as long as the penis.” (Pilsbry, 1948: 798).
}

Pilsbry (1948) may have selected the holotype for its large size; the rest of the type lot is in the 13-15 mm length range. In the past it was common for taxonomists to select the largest and "finest" specimen of a type lot rather than the most nearly average. Even the least size-dependent variable set assigned the holotype to other populations.

These findings were consistent with molecular results indicating little coherent structure among the sampled populations. The conchological variation was consistent with an interpretation that none of the sampled populations showed the type of ontogenetic divergence typically associated with different species. The findings were further consistent with an interpretation that none of the sampled populations were reproductively isolated from one another. Therefore, according to the biological species concept (Mayr, 1940), the sampled populations belonged to the same species.

\section{Soft Tissue Anatomy}

Eleven Oxyloma and one Catinella, populations sampled for this study, were readily distinguished by the presence in the Catinella of a broad penial appendix midway along the length of the penis. Oxyloma had a penial sheath; Catinella did not.

Within Oxyloma, all anatomical characters showed substantial variation. Franzen (1963) found a similar level of variation in Oxyloma retusum (Lea, 1837) from 11 localities in the Midwest from Minnesota to Kansas. The anatomical variations Franzen detected were not restricted geographically but occurred in all samples collected. Franzen (1964) reported a similar amount of variation in the penis of the other purported conspecific subspecies of Oxyloma haydeni (W.G. Binney, 1858), O. h. haydeni, from 13 localities in Nebraska. ${ }^{7}$ Örstan (2010) reported variably straight and coiled epiphallus and penis in $O$. retusum from Maryland.

No soft parts are preserved from the type lot of Oxyloma haydeni kanabense (Paul Callomon, Collections Manager Malacology Department, Academy of Natural Sciences, Philadelphia, Pennsylvania, written commun., 2007). The only information on the anatomy of the type lot was that contained in the original description (Pilsbry, 1948, p. 798, figs. 419A and 419a) ${ }^{8}$. Pilsbry's (1948) anatomical description was difficult to interpret taxonomically. The size of the hermaphrodite duct in succineid and other stylommatophoran snails is subject to great variation with time and reproductive readiness. The large size of the duct in his illustrated specimen may depict peak reproductive state. The prostate gland is said to be long, but its length, or relative length, is not quantified. The length of the prostate gland, in common with that of other soft tissues, is difficult to measure objectively. Specimens dissected for this study showed substantial variation. The fact that the penis was bent near the summit is a character of "section" (we would now say "subgenus") Neoxyloma 
(Pilsbry, 1948, p. 775), which contains nearly all North American species of Oxyloma. The observation that the epiphallus "makes about one spiral turn” (presumably, within the penial sheath) was probably specific to the individual Pilsbry examined. We found the extent and deployment of the epiphallus within the penial sheath to be variable, from merely a small jog to between two and three turns before exiting the sheath. The relative lengths of penis and vagina may be a good taxonomic character in Oxyloma, if a way of measuring it without distorting the elastic tissues could be found.

Available information did not allow dispositive comparison between $O$. h. kanabense and O. h. haydeni. Franzen's (1964, fig. 1) illustrations of variation in the content of the penial sheath of seven specimens of $O$. $h$. haydeni, showed some forms of the penial summit and appendix and the disposition of the epiphallus that were like those we observed in O. h. kanabense; however, others were different. A study that included individuals of both nominal subspecies would be more informative than trying to draw conclusions from figures in the literature.

In summary, the soft anatomy proved relatively uninformative for the purposes of this study. It may have been more useful in a broader study in which more taxa (with more differentiated reproductive systems) were included. On the other hand, the absence of compelling differences among the Oxyloma samples studied was consistent with the lack of differentiation by shell characters and, likewise, with an interpretation that none of the sampled populations were reproductively isolated from one another.

\section{Morphology and Anatomy- Taxonomic-Nomenclatural Considerations}

Solely on the basis of this study of shells and anatomy, the holotype of $O$. $h$. kanabense plausibly could be regarded as a member of the same species as the populations of Oxyloma analyzed herein. Oxyloma haydeni kanabense was, on that basis, the correct name for this group of populations.

If future studies showed no difference between O. h. kanabense and O. h. haydeni, the latter name would be the valid name for the species, having priority (by 90 years) over the former. Franzen's (1964) comparison of O. h. haydeni and $O$. retusum, although reporting differences in the penial appendix and body coloration, leaves open the possibility that the still earlier name $O$. retusum may be yet another senior synonym.

\footnotetext{
9“Most subspecies are recognizably differentiated populations which are not considered sufficiently distinct to be called species" (Pilsbry, 1939, p. xiv). "In ambiguous situations it is ... advantageous to treat allopatric populations of doubtful rank as subspecies.” (Mayr, 2000, p. 26).
}

On the question of whether $O . h$. kanabense is a species or subspecies: much modern taxonomy would consider this a non-issue. In a highly regarded proposal by de Queiroz (2005), a species is a separately evolving metapopulation lineage, where a metapopulation is an inclusive population made up of a set of connected subpopulations and a lineage is a population extended through time or an ancestral-descendant series of time-limited (instantaneous) populations. Such a species may or may not be fully isolated in a reproductive sense from other such entities - the essential condition of the biological species concept of Mayr (1940). Although theoretically possible, observations of presence or absence of interbreeding among land snail populations are limited. More often, the judgment of what is a given land snail species has been based on degree of difference criteria and the distribution of character states through an array of specimens. Moreover, reproductive isolation is but one possible contingent property of a species defined as an evolving metapopulation lineage. Other authors have called attention to the apparent maintenance of separation between metapopulation lineages (as evidenced by distinctive ecologies and morphologies) that appear to exchange genes more or less freely (de Queiroz, 2005). A corollary of the metapopulation lineage proposal is that all separately evolving metapopulation lineages are species. The taxonomy of North American land mollusks inherited from Pilsbry and his successors includes numerous subspecies, also recognized on degree of phenetic difference, subjectively judged. ${ }^{9}$ There is no generally agreed-on rule regarding their formal taxonomic recognition. Because under the species concept argued here, all separately evolving metapopulation lineages are species, the least inclusive taxon in formal taxonomy would be the species. This also is the conclusion of proponents of phylogenetic species concepts (Mishler and Theriot, 2000; Wheeler and Platnick, 2000). Where they exist, well-defined, diagnosable "subspecies" of the Pilsbryan system are simply called species. What is "well defined" remains a taxonomist's judgment call, but arbitrary decisions on rank (and guesses about reproductive isolation) are less a factor than before.

\section{Genetics}

In a molecular genetic study, it is essential to analyze the markers separately prior to combining them. This allows an examination of marked changes (an undesirable result) upon combining into large concatenated datasets. Combining markers should not change the results but should strengthen the support. 


\section{Each Marker Separate}

The failure of many samples to amplify DNA fragments for subsequent sequencing was noteworthy. DNA template degradation could be ruled out for most of our samples, as samples that dropped for one locus readily amplified for other loci. Amplification failures could be caused by SNPs in the primer regions. If a SNP occurs at or close to the 3-prime end of a primer sequence, the DNA polymerase is unable to "sit down" on the template and begin extension. As we developed and optimized our primers from sequences derived from Vaseys Paradise specimens, no such "drop-outs” were observed in this population (or the Elves Chasm population). Consequently, “drop-outs” likely bear some SNP information. Unfortunately, this information was difficult to quantify other than that one or more SNPs between the Vaseys Paradise population and the "drop-out" specimens or populations were likely in one or both primer sequences. Conclusions of the position of such specimens or populations in a phylogenetic or population genetics context could not be drawn.

Likely for the same reason, outgroup specimens from the genus Catinella failed to amplify for all nuclear loci. This was not surprising, as the probability of a SNP at a certain position increases with increasing phylogenetic distance. It was especially challenging to find conserved areas for primers and adjacent, sufficiently variable areas with resolution, at the genera-species-population level in the nuclear genome. However, the outgroups of Catinella, Succinea and Neosuccinea provided the ability to root the mtDNA tree and indicated that Indian Garden was the first population to branch after the outgroup, followed by Sevier River, Glendale Highway, Center Creek, Three Lakes, Escalante River, Panguitch Creek, Upper Panguitch (Pole Creek), Lees Ferry, The Greens, and Vaseys Paradise. Vaseys Paradise was the most recent branch or lineage among these Utah and Arizona populations (along with the three outlier specimens from The Greens), when an outgroup root was used.

Based on genetic distance $\left(\mathrm{F}_{\mathrm{st}}\right)$, about three-fourths of the observed variability was among populations, which indicated some, but limited, gene flow (table 8). When comparing pairwise $\mathrm{F}_{\mathrm{st}}$ values for all populations and visualizing the results in MDS plots (not shown), no consistent population groupings over several loci were observed, with the exception of the Vaseys Paradise population that appeared more distant from other populations in the mitochondrial loci. The significance of this observation was unclear in light of evidence provided by other loci; it was possible that this pattern simply reflected the stochastic evolutionary process. Given the range of pairwise $\mathrm{F}_{\text {st }}$ values for all populations fell somewhere on a continuum from the lowest of 0.29 (Sevier and Three Lakes) to the highest of 0.99 (Vaseys Paradise and Lees Ferry), we estimated the relative migrations rates to be zero per generation between Vaseys Paradise and Lees Ferry, indicating almost complete subdivision and greater than or equal to 1 per generation between Sevier and Three Lakes. If interpreted literally, the results indicated a gene flow rate between Sevier River and Three Lakes that was sufficient to prevent complete differentiation, which could be as much as one per generation (Mills and Allendorf, 1996). However, if long-distance dispersal occurred from one source population into two different recipient populations, this process would mimic gene flow between the recipient populations when they instead only shared a recent connection to the source population. Overall, we observed a significant positive correlation between genetic and geographic distance between populations at one mtDNA locus and two of the nDNA loci. This indicated that the isolation-by-distance model applies to some extent, although only weak patterns existed.

Significant results for population expansion (Tajima's D, Fu's $F_{s}, R_{2}$ and mismatch distribution) were seen in all populations except Indian Garden, The Greens, and to some degree, Sevier River. These results were most consistent across tests in the Lees Ferry, Vaseys Paradise, and Glendale Highway populations. As population expansions usually followed bottlenecks (such as recent population founder events), this scenario is likely for the latter three populations, and to a lesser degree for all populations with the possible exception of Indian Garden, The Greens, and Sevier River.

After much technical difficulty, we were able to successfully amplify one microsatellite DNA locus in the Oxyloma populations for this study (fig. 23). Although one microsatellite marker was not sufficient to draw scientifically rigorous conclusions, the analysis produced some useful basic information. The microsatellite results, with The Greens and Three Lakes containing most of the known allelic diversity, were consistent with our suggestion that The Greens may represent most of the genetic diversity for this area and may be a potential "hub" for long-distance dispersal events. The other populations showed a relatively reduced allele diversity, with four populations that are monomorphic (homozygous) and Vaseys Paradise showing only two alleles (the second allele only in heterozygous specimens).

Our phylogenetic analyses show that the nominal Kanab ambersnail, defined in the literature during the 1900s, was not monophyletic because The Greens (type locality) was not monophyletic with the Vaseys Paradise and Three Lakes populations (the only known Kanab ambersnail populations at the time of this study). This result agreed with a cyt $b$ study on this group of snails with a much broader geographic sampling scheme (Stevens and others, 2000).

We observed predominately shallow structure among the 11 Oxyloma populations sampled in Arizona and Utah using 2 mitochondrial DNA markers and 4 nuclear loci (which included Vaseys Paradise, Arizona, Three Lakes, Utah, and the type locality of The Greens, Utah). Likewise, STRUCTURE analyses of the AFLP data highlighted the general differentiation of populations, although some mixing of populations was apparent (fig. 23). The single nuclear microsatellite locus suggested similar patterns, as there tended to be limited sharing of microsatellite alleles among most populations (fig. 21). Overall, these patterns suggested that southwestern Oxyloma populations generally tended to 
be genetically differentiated. Furthermore, these findings suggested that the "Kanab ambersnail" taxonomic designation was not valid. If it were valid, we would have expected to detect genetic clusters of specimens from Vaseys Paradise, Three Lakes, and The Greens. Instead, our findings tended to indicate the relatively similar differentiation of all populations.

Using DNA sequences from four nuclear genes, we did not observe structure consistent with that of the mitochondrial DNA, microsatellites, or AFLPs. Because mitochondrial DNA has a more rapid evolutionary rate (about ten times as rapid in humans) and a smaller effective population size than nuclear DNA, it is not unusual to see more structure using mitochondrial markers relative to nuclear markers. Likewise, microsatellite loci can show stronger genetic structure patterns than most nuclear genes because of their high mutation rates compared to non-microsatellite nuclear DNA (Ellegren, 2004). Our analyses of AFLP markers adopted the standard practice of focusing solely on variable loci and excluded all monomorphic bands (Bensch and Åkesson, 2005; Foll and others 2008). Consequently, AFLP marker datasets generally tended to reflect more diverse, faster-evolving loci than background nuclear genomic regions.

It is not considered scientifically rigorous to make conclusions on species or other major taxonomic statuses (such as ESUs) based on only one molecular marker. Our criterion for defining significant structure or taxonomic category was a corroboration of mitochondrial and nuclear markers; this criterion is well accepted as a taxonomic standard (Moritz, 1994). Because the nuclear markers indicated gene flow among populations, our combined results are consistent with this group of populations belonging to the same species. However, within a species, certain populations that show monophyletic origins and are geographically separated from other populations would potentially fit the definition of a separate ESU. In this study, although our nuclear genes and random regions did not support distinct populations, our more rapidly evolving markers (AFLP, microsatellite, mtDNA genes) indicated the presence of distinct populations at levels below the species level. In particular, two populations, Vaseys Paradise and Escalante River, showed monophyletic origins for mitochondrial markers, whereas AFLPs and microsatellite alleles suggested the presence of distinct groups.

From the structure observed using both mitochondrial DNA markers, the Vaseys Paradise population was the most distant population from the others. However, 3 samples from The Greens (in Utah) were even more distant (by a factor of about 10) than the Vaseys Paradise population; the other 22 samples from The Greens cluster with the other Oxyloma populations in this study area. Additionally, one sample from the Three Lakes population (9-12) did not cluster with the population from which it was sampled in any of our mtDNA analyses. All four of these samples were included in the nuclear dataset and showed no signs of distinctiveness, but shared haplotypes with a number of other samples. Stevens and others (2000) found one specimen (21.185ALB) from an
Alberta, Canada, population showing almost exactly the same pattern and distance as samples from Arizona and Utah in their cyt $b$ analysis. In a follow-up to this study, we sampled museum specimens of Oxyloma haydeni from Canada and several of those individuals clustered closely with the 3 The Greens outliers and also with the Three Lakes outlier. This indicated that the presence of divergent lineages in these populations (The Greens and Three Lakes) resulted from long-distance dispersal events from as far away as Canada. Although snails appear comparatively immobile, longdistance dispersal over several thousand kilometers has been demonstrated for pulmonate gastropods (Gittenberger and others, 2006). Migrating birds are possible vectors by carrying the snails in their feathers, feet, or digestive tract (Green and Figuerola, 2005; Wada and others, 2011). As for the three The Greens specimens and the single Three Lakes specimen, the most likely explanation was an immigration event involving one or very few specimens from a distant population.

A different type of dispersal event observed in this dataset was short-distance dispersal. An example of short-distance dispersal of an mtDNA haplotype could be seen in our cyt $b$ dataset: one specimen from Vaseys Paradise (4-20) was placed within the Lees Ferry population clade and shared the same haplotype with 20 individuals from that location. Lees Ferry is located upstream of Vaseys Paradise along the Colorado River within the Grand Canyon. The Lees Ferry cyt $b$ haplotype may have reached Vaseys Paradise on drifting plant material, by bird transportation, or by other means.

The Vaseys Paradise population had longer branch lengths than the other populations sampled in many of our mtDNA analyses. However, our combined analyses indicated that the Vaseys Paradise group was the most recent lineage of all the Arizona and Utah populations after outgroups were included and a rooted tree topology was obtained. We suspected the Vaseys Paradise population had experienced unusual population demographic events such as a founder event followed by one or more bottlenecks. Multiple lines of evidence supported this viewpoint: (1) population expansion was indicated by a number of tests for the Vaseys Paradise population (as it was for Lees Ferry and Glendale Highway); (2) repeated population expansion and contraction events could have led to lineage sorting (as observed in the Elves Chasm population, which was a known human-mediated bottleneck) and could explain the observed greater diversity of other populations when compared to the Vaseys Paradise, Elves Chasm, Lees Ferry, and Glendale Highway populations; and (3) the comparatively isolated small habitat situated on a steep slope at the waterline of the Colorado River (at Vaseys Paradise) likely allowed for repeated flooding of the habitat. Considering this scenario, the natural Colorado River dynamics in the Grand Canyon may have contributed to the genetic distinctiveness of the Vaseys Paradise population. The lack of nuclear and mitochondrial marker variability in the Lees Ferry and Glendale Highway populations also suggested relatively recent founder events or severe bottlenecks. 


\section{Markers Combined}

In this study, primarily AFLPs, mtDNA, and even the microsatellite locus showed structuring among populations. However, the distribution of all other genetic markers and morphological characters among the samples could be interpreted as no isolation. Our taxonomic conclusion, therefore, is that all studied samples of Oxyloma were drawn from populations of the same species.

The conclusions of this study are far more definitive and comprehensive than those provided by Stevens and others (2000). The current investigation relied on a greater numerical sampling of locations and individuals, a more focused and taxonomically relevant set of southwestern ambersnail populations, and a substantially larger panel of genetic markers. Although similar patterns have been identified in all studies, the more substantial data associated with the current project allowed us to understand better the relevance of the allele frequency differences. Our findings suggested that the genetic structure patterns may partially reflect periodic longdistance migration and establishment of populations by one or a few individuals rather than long-term population divergence.

In studies of another snail species, Succinea caduca, an endemic ambersnail from Hawaii, Holland and Cowie (2007) used the mtDNA COI and 16S ribosomal ribonucleic acid genes to examine genetic lineages and population diversification among islands. They expected to find a pattern of lineage evolution representing a progressive linear dispersal from island to island. Instead, they found that the S. caduca lineage predated the age of the islands and likely arose on an older island, and later dispersed to the Hawaiian Islands. This result was confirmed by Holland and Cowie (2007), using the same mtDNA markers, and one nuclear DNA marker (18S ribosomal ribonucleic acid). The 2008 paper also revealed multiple dispersals onto several of the islands. The dispersal they observed, island to island, sometimes occurring multiple times on the same island, is similar to our inferred "long-distance" dispersal with locations such as The Greens and Three Lakes receiving higher rates of dispersal than other populations (based on our single microsatellite locus; fig. 21).

The observed genetic patterns were in agreement with the species' reproductive and dispersal strategies. Passive short-distance and long-distance dispersal in snails also was documented as occurring in amber snails from the Hawaiian Islands (Holland and Cowie, 2007), where suitable habitat and populations over large geographic areas contributed to panmixia. In this study, less suitable habitat areas with small, island-like, and comparatively isolated, habitat patches, such as the habitats for Oxyloma in Arizona and Utah, contribute to much of genetic structure observed in AFLP and mitochondrial DNA. However, Oxyloma are capable of selfing (Patterson, 1970), which enables a single specimen to found a population.
Subsequent gene flow by new immigrants contributed to increased genetic diversity, which countered reproductive isolation. How frequently gene flow between populations occurred is a function of factors such as geographic isolation, concordance with bird migratory routes, river flow directions, and so on. The pattern observed in this study agrees with a model of different populations showing varying degrees of isolation with limited gene flow. The populations of Lees Ferry and Glendale Highway showed a low genetic diversity, possibly a result of a recent demographic event. That no such signals were seen in the nuclear loci is not surprising, as all the tests are either completely or partly based on the occurrence of singletons in the dataset. In a recent expansion event, not enough time may have passed for a sufficient number of singletons to occur. Similarly, demographic events likely have led to the genetic structure observed in the Vaseys Paradise population from this study, as described in Mitochondrial DNA and Nuclear DNA in the Results section. On the other side of the spectrum, The Greens showed a comparatively large amount of genetic diversity and signs of recent population expansion. This could have been caused by a large population size, frequent immigrants from source populations possibly situated outside the geographic context of this study (long-distance dispersal events), or both. Furthermore, The Greens population could be seen as a source population ("hub") for migrants to other populations within this study area. Similar to The Greens, the Sevier River population showed much diversity of haplotypes with relationships to many other populations in all genetic markers. This suggested that Sevier River might be another source population like The Greens. The observed genetic diversity at the Sevier River location could be accounted for by short-distance dispersal events between populations in this study. These hypotheses, incorporating a mixture of long-distance and short-distance dispersal events, were consistent with the observed haplotype diversity and distribution in haplotype analyses results. Additionally, the phylogenetic pattern of shallow structure and recent lineages was more consistent with an explanation of long-distance dispersal versus ancient vicariance and long-term evolution in situ. This is a story of dispersal, sometimes over very long distances, and colonization of populations, occasionally by single individuals.

\section{Conservation Implications}

The validity of the Kanab ambersnail taxonomic unit (Oxyloma haydeni kanabense) was not supported because Vaseys Paradise did not cluster with the type localities of Three Lakes and The Greens. We suggest that the ambersnail populations in this study area generally were undergoing a dynamic process of long-distance and short-distance dispersals 
with most lineages being fairly recent as reflected in the shallow structure of our trees. Additionally, the ambersnail life history supports frequent colonization events with snail dispersal over short and long distances. The ambersnail's ability for selfing, and, therefore, for colonization, by one single individual may explain genetically distinct populations, which arise in a short period of time. If this were the case, the question arises of whether these genetically distinguishable populations should be characterized as ESUs or subspecies. Going back to the O'Brien and Mayr (1991) definition of a subspecies, a subspecies would share (a) a unique geographic range, (b) a set of "phylogenetically concordant phenotypic characters," (c) a suite of molecular genetic similarities, and (d) derived adaptations relative to other subspecies. Some populations from this study arguably fit criteria a, and c; however, we did not find evidence for divisions below the species level to support criteria b or d. The O'Brien and Mayr definition applies mainly to population histories over extended time periods and with vicariance events that give rise to independently evolving lineages and metapopulations. Therefore, the definition does not fit the proposed model of colonization and possible extinction ("boom and bust”) of ambersnail populations in the Southwest, with its history of random, "non-phylogenetic" signatures. A consequential question arises here: Is it worthwhile to protect, as endangered, each population of ambersnails that may be founded by recent dispersal events that may be an integral part of these organisms' life history, rather than populations that exist as long-time unique evolutionary lineages? We suggest that, by protecting a habitat and its dynamics to allow the continuation of future dispersals and colonizations to occur, this dynamic process may continue uninterrupted just as well as by protecting each genetically unique population. Some genetically unique populations in this system may be naturally short-lived, as dispersal and colonization strategies in marginal habitats may suggest. Some of the observed genetic uniqueness (for example, in the Vaseys Paradise population), may actually be caused and managed by re-occurring dramatic events such as floods, which have severe demographic effects.

\section{Future Research}

Future research would usefully include similar analyses of additional populations from the species' range (farther north [Canada] and farther south [Mexico]) to better understand dispersal patterns, and additionally, should examine larger microsatellite or SNP marker sets to address fine-scale population genetics and parentage questions (such as the role of selfing). These areas of inquiry are less relevant for the Grand Canyon conservation effort than for snail conservation and biology in general.

\section{Summary}

Because of controversy regarding taxonomy of Oxyloma and the endangered Kanab ambersnail at the time this study began, new detailed and scientifically rigorous analyses were completed of morphological and genetic variation from ambersnail specimens collected at 12 locations in Arizona and Utah and some comparison individuals from farther north including Canada. These new data have allowed for the evaluation of Kanab ambersnail taxonomy from the standpoint of shell morphology and reproductive anatomy as well as from molecular genetics. Morphology and anatomy indicate that the holotype of Oxyloma haydeni kanabense plausibly can be regarded as a member of the same species as the populations of Oxyloma analyzed in this study. Genetic data indicate the presence of gene flow among all populations, evidence that they are members of the same species. Almost all the observed genetic diversity can be accounted for by short- or long-distance dispersal events between populations in this study. Our major taxonomic conclusion is that all samples collected for this study were drawn from populations of the same species. The combined analyses in this study and resulting conclusions produced some useful basic information for taxonomic classification and management of Oxyloma in Arizona and Utah.

\section{Acknowledgments}

We would like to thank the USGS Grand Canyon Monitoring and Research Center for funding this study and encouraging us to write our grant proposal. The Bureau of Reclamation and U.S. Fish and Wildlife Service also partially funded this study. We thank Larry Stevens of the Grand Canyon Wildlands Council for his help on previous Kanab ambersnail work, the entire Kanab Ambersnail Working Group for helpful discussions at working group meetings, and Darren Bolen, Dan Cox, and Clay Nelson of the Arizona Game and Fish Department for collection of many of the samples. Finally, we thank Anna Carlson for help with genetic laboratory work and Mickey Reed for cartographic products. 


\section{References Cited}

Armbruster, G.F.J., van Moorsel, C.H.M., and Gittenberger, Edmund, 2000, Conserved sequence patterns in the noncoding ribosomal ITS-1 of distantly related snail taxa: Journal of Molluscan Studies, v. 66, no. 4, p. 570-573.

Avise, J.C., 1991, Ten unorthodox perspectives on evolution prompted by comparative population genetic findings on mitochondrial DNA: Annual Review of Genetics, v. 25, p. 45-69.

Avise, J.C., and Ball, R.M., Jr., 1990, Principles of genealogical concordance in species concepts and biological taxonomy: Oxford Surveys in Evolutionary Biology, v. 7, p. 45-67.

Bandelt, H-J., Forster, Peter, and Röhl, Arne, 1999, Medianjoining networks for inferring intraspecific phylogenies: Molecular Biology and Evolution, v. 15, no. 1, p. 37-48, accessed May 13, 2013, at http://www.fluxus-engineering. com/sharepub.htm\#a1/.

Barrowclough, G.F., 1982, Geographic variation, predictiveness, and subspecies: The Auk, v. 99, no. 3, p. 601-603.

Benham, James, 2001, Genographer: computer software: University of Hawaii Web site, accessed May 12, 2013, at http://www2.hawaii.edu/ durrell/Software/1FA1F517DC84-4314-AA4D-764B8F7A327D.html.

Bensch, Staffan, and Åkesson, M., 2005, Ten years of AFLP in ecology and evolution-Why so few animals?: Molecular Ecology, v. 14, p. 2899-2914.

Binney, W.G., 1858, Notes on American land shells-No. 3: Proceedings of the Academy of Natural Sciences of Philadelphia, v. 10, p. 114-116.

Brown, W.M., 1983, Evolution of animal mitochondrial DNA, in Nei, M., and Koehn, R.K., eds., Evolution of genes and proteins: Sunderland, Mass., Sinauer Associates, p. 62-88.

Brown, W.M., 1985, The mitochondrial genome of animals, in MacIntyre, R.J., ed., Molecular Evolutionary Genetics: New York, Plenum Press, p. 95-130.

Chow, Seinen, and Hazama, Kazushige, 1998, Universal PCR primers for $\mathrm{S} 7$ ribosomal protein gene introns in fish: Molecular Ecology, v. 7, p. 1247-1263.

de Queiroz, Kevin, 2005, Ernst Mayr and the modern concept of species: Proceedings of the National Academy of Sciences, v. 102, p. 6600-6607.
Edwards, Al, Hammond, H.A., Jin, Li, Caskey, C.T., and Chakraborty, Ranajit, 1992, Genetic variation at five trimeric and tetrameric tandem repeat loci in four human population groups: Genomics, v. 12, no. 2, p. 241-253.

Ellegren, Hans, 2004, Microsatellites-Simple sequences with complex evolution: Nature Reviews Genetics, v. 5, p. 435-445.

Excoffier, Laurent, Laval, Guillaume, and Schneider, Stefan, 2006, Arlequin version 3.1-A software program for population genetics data analysis: Bern, Switzerland, Computational and Molecular Population Genetics. Web site accessed [May 13, 2013] at http://cmpg.unibe.ch/ software/arlequin3.

Excoffier, Laurent, Smouse, P.E., and Quattro, J.M., 1992, Analysis of molecular variance inferred from metric distances among DNA haplotypes-Application to human mitochondrial DNA restriction data: Genetics, v. 131, no. 2, p. 479-491.

Foll, Matthieu, Beaumont, M.A., and Gaggiotti, Oscar, 2008, An approximate Bayesian computation approach to overcome biases that arise when using amplified fragment length polymorphism markers to study population structure: Genetics, v. 179, no. 2, p. 927-939.

Folmer, Ole, Black, M.B., Hoeh, W.R., Lutz, R.A., and Vrijenhoek, R.C., 1994, DNA primers for amplification of mitochondrial cytochrome $c$ oxidase subunit I from diverse metazoan invertebrates: Molecular Marine Biology and Biotechnology, v. 3, no. 5, p. 294-299.

Franzen, D.S., 1964, Anatomy of the succineid gastropod Oxyloma haydeni: The Nautilus, v. 77, p. 73-81.

Franzen, D.S., 1963, Variations in the anatomy of the succineid gastropod Oxyloma retusa: The Nautilus, v. 76, p. 82-95.

Fu, Y.X., 1997, Statistical tests of neutrality of mutations against population growth, hitchhiking and background selection: Genetics, v. 147, no. 2, p. 915-925.

Galler, Lynne, and Gould, S.J., 1979, The morphology of a "hybrid zone," in Cerion: variation, clines, and an ontogenetic relationship between two "species" in Cuba: Evolution, v. 33, no. 2, p. 714-727.

Gene Codes Corporation, 2010, Sequencher version 4.2.2: Gene Codes Corporation Web page, accessed June 27, 2013, at http://genecodes.com/.

Gill, F.B., 1982, Might there be a resurrection of the subspecies?: The Auk, v. 99, p. 598-599.

Gittenberger, Edmund, Groenenberg, D.S.J., Kokshoorn, Bas, and Preece, R.C., 2006, Molecular trails from hitch-hiking snails: Nature, v. 439, p. 409. 
Goodfriend, G.A., 1986, Variation in land-snail shell form and size and its causes-A review: Systematic Biology, v. 35, no. 2, p. 204-223.

Gould, S.J., 1969, An evolutionary microcosm-Pleistocene and recent history of the land snail $P$. (Poecilozonites) in Bermuda: Bulletin of the Museum of Comparative Zoology, v. 138, p. 407-531.

Graur, Dan, and Li, W.-H., 2000, Fundamentals of molecular evolution (2d ed.): Sunderland, Mass., Sinauer Associates, 439 p.

Green, A.J., and Figuerola, Jordi, 2005, Recent advances in the study of long-distance dispersal of aquatic invertebrates via birds: Diversity and Distributions, v. 11, no. 2, p. 149-156.

Gyllensten, Ulf, Wharton, Dan, Josefsson, Agneta, and Wilson, A.C., 1991, Paternal inheritance of mitochondrial DNA in mice: Nature, v. 352, p. 255-257.

Hamilton, M.B., Pincus, E.L., Di Fiore, Anthony, and Fleischer, R.C., 1999, Universal linker and ligation procedures for construction of genomic DNA libraries enriched for microsatellites: BioTechniques, v. 27, no. 3, p. 500-507.

Harris, S.A., and Hubricht, Leslie, 1982, Distribution of the species of the genus Oxyloma (Mollusca, Succineidae) in southern Canada and the adjacent portions of the United States: Canadian Journal of Zoology, v. 60, no. 7, p. 1607-1611.

Harrison, R.G., 1989, Animal mitochondrial DNA as a genetic marker in population and evolutionary biology: Trends in Ecology and Evolution, v. 4, no. 1, p. 6-11.

Hoagland, K.E., and Davis, G.M., 1987, The succineid snail fauna of Chittenango Falls, New York-Taxonomic status with comparisons to other relevant taxa: Proceedings of the Academy of Natural Sciences of Philadelphia, v. 139, p. 465-526.

Holland, B.S., and Cowie, R.H., 2007, A geographic mosaic of passive dispersal-Population structure in the endemic Kawaiian amber snail Succinea caduca (Mighels, 1845): Molecular Ecology, v. 16, no. 12, p. 2422-2435.

Kohn, A.J., and Riggs, A.C., 1975, Morphometry of the Conus shell: Systematic Biology, v. 24, no. 3, p. 346-359.

Lea, Isaac, 1837, Observations on the naiades; and descriptions of new species of that and other families, second supplement: Transactions of the American Philosophical Society, New Series, v. 5, p. 23-119.
Lee, Taehwan, and Foighil, D.Ó., 2002, 6-Phosphogluconate dehydrogenase (PGD) allele phylogeny is incongruent with a recent origin of polyploidization in some North American Sphaeriidae (Mollusca, Bivalvia): Molecular Phylogenetics and Evolution, v. 25, no. 1, p. 112-124.

Life Technologies Corp., 2013, Applied biosystemsIntegrated systems for genetic analysis: Life Technologies Corporation Web site, accessed June 27, 2013, at http:// www.invitrogen.com/site/us/en/home/brands/AppliedBiosystems.html.

Lindberg, D.R., 1985, Shell sexual dimorphism of Margarites vorticifera-Multivariant analysis and taxonomic implications: Malacological Review, v. 18, no. 1-2, p. 1-8.

Maddison, D.R., and Maddison, W.P., 2001, MacClade 4: Sunderland, Mass., Sinauer Associates, 500 p.

Mayr, Ernst, 1940, Speciation phenomena in birds: American Naturalist, v. 74, no. 752, p. 249-278.

Mayr, Ernst, 1982, Of what use are subspecies?: The Auk, v. 99, no. 3, p. 593-595.

Mayr, Ernst, 2000, The biological species concept, in Wheeler, Q.D., and Meier, Rudolf, eds., Species concepts and phylogenetic theory-A debate: New York, Columbia University Press, 230 p.

Meretsky, V.J., North, E.G., and Stevens, L.E., 2002, Kanab ambersnail and other terrestrial snails in South Central Utah: Western North American Naturalist, v. 62, no. 3, p. 307-315.

Meretsky, V.J., Wegner, D.L., and Stevens, L.E., 2000, Balancing endangered species and ecosystems-A case study of adaptive management in Grand Canyon: Environmental Management, v. 25, no. 6, p. 579-586.

Merritt, T.J.S., Shi, L., Chase, M.C., Rex, M.A., Etter, R.J., and Quattro, J.M., 1998, Universal cytochrome $b$ primers facilitate intraspecific studies in molluscan taxa: Molecular Marine Biology and Biotechnology, v. 7, no. 1, p. 7-11.

Miller, M.P., Stevens, L.E., Busch, J.D., Sorensen, J.A., and Keim, Paul, 2000, Amplified fragment length polymorphism and mitochondrial sequence data detect genetic differentiation and relationships in endangered southwestern USA ambersnails (Oxyloma spp.): Canadian Journal of Zoology, v. 78, no. 10, p. 1845-1854.

Miller, M.P., Weigel, D.E., Mock, K.E., and Roth, Barry, 2006, Evidence for an outcrossing reproductive strategy in the hermaphroditic heterobranch gastropod Valvata utahensis (Valvatidae), with notes on the genetic differentiation of $V$. utahensis and $V$. humeralis: Journal of Molluscan Studies, v. 72, no. 4, p. 397-403. 
Mills, L.S., and Allendorf, F.W., 1996, The one-migrantper-generation rule in conservation and management: Conservation Biology, v. 10, no. 6, p. 1509-1518.

Mishler, B.D., and Theriot, E.C., 2000, The phylogenetic species concept (sensu Mishler and Theriot)-Monophyly, apomorphy, and phylogenetic species concepts, in Wheeler, Q.D., and Meier, Rudolf, eds., Species concepts and phylogenetic theory-A debate: New York, Columbia University Press, 230 p.

Moritz, Craig, 1994, Defining 'Evolutionarily Significant Units' for conservation: Trends in Ecology and Evolution, v. 9, no. 10, p. 373-375.

Moritz, Craig, Dowling, T.E., and Brown, W.M., 1987, Evolution of animal mitochondrial DNA-Relevance for population biology and systematics: Annual Review of Ecology and Systematics, v. 18, p. 269-292.

O’Brien, S.J., and Mayr, Ernst, 1991, Bureaucratic mischiefRecognizing endangered species and subspecies: Science, v. 251, no. 4998, p. 1187-1188.

Örstan, Aydin, 2010, Reproductive biology and annual population cycle of Oxyloma retusum (Pulmonata Succineidae): American Malacological Bulletin, v. 28, p. 113-120.

Patterson, C.M., 1973, Generic and specific characters in the land snail family Succineidae: Malacological Review, v. 6, p. 54-56.

Patterson, C.M., 1970, Self-fertilization in the land snail family Succineidae: Journal of Conchology, v. 108, p. 61-62.

Pilsbry, H.A., 1939, Land mollusca of North America (north of Mexico): The Academy of Natural Sciences of Philadelphia, Monographs, no. 3, v. 1, part 1, p. i-Xvii and 1-573.

Pilsbry, H.A., 1948, Land mollusca of North America (north of Mexico): The Academy of Natural Sciences of Philadelphia, Monographs, no. 3, v. 2, part 2, p. i-xlviii and 521-1113.

Pilsbry, H.A., and Ferris, J.H., 1911, Mollusca of the southwestern states, V-The Grand Canyon and northern Arizona: Proceedings of the Academy of Natural Sciences of Philadelphia , v. 63., no. 1, p. 174-199.

Posada, David, and Crandall, K.A., 1998, MODELTESTTesting the model of DNA substitution: Bioinformatics, v. 14, no. 9, p. 817-818.

Pritchard, J.K., Stephens, Matthew, and Donnelly, Peter, 2000, Inference of population structure using multilocus genotype data: Genetics, v. 155, p. 945-959, accessed May 13, 2013, at http://pritch.bsd.uchicago.edu/structure.html.
Rambaut, Andrew, and Drummond, A.J., 2005, TracerMCMC Trace File Analyser, version 1.5 Oxford, United Kingdom, University of Oxford Web site, accessed November 26, 2012, at http://tree.bio.ed.ac.uk/software/ tracer/.

Ramos-Onsins, S.E., and Rozas, Julio, 2002, Statistical properties of new neutrality tests against population growth: Molecular Biology and Evolution, v. 19, no. 12, p. 2092-2100.

Raup, D.M., 1966, Geometric analysis of shell coilingGeneral problems: Journal of Paleontology, v. 40, no. 5, p. 1178-1190.

Rogers, A.R., and Harpending, H.C., 1992, Population growth makes waves in the distribution of pairwise genetic differences: Molecular Biology and Evolution, v. 9, no. 3, p. 552-569.

Ronquist, Fredrik, and Huelsenbeck, J.P., 2003, MrBayes 3-Bayesian phylogenetic inference under mixed models: Bioinformatics, v. 19, no. 12, p. 1572-1574.

Rosenberg, N.A., 2004, DISTRUCT-A program for the graphical display of population structure: Molecular Ecology Notes, v. 4, no. 1, p. 137-138.

Rosselló, J.A., Lázaro, Amparo, Cosín, Raúl, and Molins, Arántzazu, 2007, A phylogeographic split in Buxus balearica (Buxaceae) as evidenced by nuclear ribosomal markers-When ITS paralogues are welcome: Journal of Molecular Evolution, v. 64, no. 2, p. 143-157.

Roth, Barry, 2004, Observations on the taxonomy and range of Hesperarion Simroth, 1891 and the evidence for genital polymorphism in Ariolimax Mörch, 1860 (GastropodaPulmonata-Arionidae-Ariolimacinae): The Veliger, v. 47, no. 1, p. 38-46.

Rozas, Julio, Sánchez-DelBarrio, J.C., Messeguer, Xavier, and Rozas, Ricardo, 2003, DnaSP, DNA polymorphism analyses by the coalescent and other methods: Bioinformatics, v. 19, no. 18, p. 2496-2497.

Rozen, Steve, and Skaletzky, H.J., 2000, Primer3 on the WWW for general users and for biologist programmers, in Krawetz, S.A., and Misener, Stephen, eds., Bioinformatics methods and protocols: methods in molecular biology: Totowa, New Jersey, Humana Press, p. 365-386.

Scott, J.M., Goble, D.D., and Davis, F.W., eds., 2006, The Endangered Species Act at thirty-Conserving biodiversity in human-dominated landscapes, v. 2: Washington, D.C., Island Press, 360 p.

Shaklee, J.B., and Tamaru, C.S., 1981, Biochemical and morphological evolution of Hawaiian bonefishes (Albula): Systematic Zoology, v. 30, no. 2, p. 125-146. 
Slatkin, Montgomery, and Maddison, W.P., 1990, Detecting isolation by distance using phylogenies of genes: Genetics, v. 126, p. 249-260.

Sokolova, I.M., and Boulding, E.G., 2004, Length polymorphisms in an intron of aminopeptidase $\mathrm{N}$ provide a useful nuclear DNA marker for Littorina species (Caenogastropoda): Journal of Molluscan Studies, v. 70, no. 2, p. 165-172.

Spamer, E.E., and Bogan, A.E., 1993, Mollusca of the Grand Canyon and vicinity, Arizona-New and revised data on diversity and distributions, with notes on PleistoceneHolocene mollusks of the Grand Canyon: Proceedings of the Academy of Natural Sciences of Philadelphia, v. 144, p. 21-68.

Stamatakis, Alexandros, 2006, RAxML-VI-HPC-Maximum likelihood-based phylogenetic analyses with thousands of taxa and mixed models: Bioinformatics, v. 22, no. 21, p. 2688-2690.

Stephens, Matthew, and Scheet, Paul, 2005, Accounting for decay of linkage disequilibrium in haplotype inference and missing-data imputation: American Journal of Human Genetics, v. 76, no. 3, p. 449-462.

Stephens, Matthew, Smith, N.J., and Donnelly, Peter, 2001, A new statistical method for haplotype reconstruction from population data: American Journal of Human Genetics, v. 68, no. 4, p. 978-989.

Stevens, L.E., Ayers, T.J., Bennett, J.B., Christensen, Kerry, Kearsley, M.J.C., Meretsky, V.J., Phillips, A.M., III, Parnell, R.A., Spence, John, Sogge, M.K., Springer, A.E., and Wegner, D.L., 2001, Planned flooding and Colorado River riparian trade-offs downstream from Glen Canyon Dam, Arizona: Ecological Applications, v. 11, no. 3, p. 701-710.

Stevens, L.E., Keim, Paul, Miller, M.P., and Wu, S.-K., 2000, Morphological and genetic relatedness among succineid landsnails in the United States and Canada, with emphasis on the endangered Kanab ambersnail (Oxyloma haydeni kanabensis): Prepared for Grand Canyon Monitoring and Research Center by Bureau of Reclamation, Contract 98-FC-40-1230, 60 p., accessed November 26, 2012, at http://www.gcmrc.gov/library/reports/biological/terrestrial/ KAS/Stevens2000.pdf.

Swofford, D.L., 2002, PAUP*_Phylogenetic Analysis Using Parsimony (* and other methods), version 4: Sunderland, Mass., Sinauer Associates.

Tajima, Fumio, 1989, The effect of change in population size on DNA polymorphism: Genetics, v. 123, p. 597-601.

Tautz, Diethard, 1989, Hypervariability of simple sequences as a general source for polymorphic DNA markers: Nucleic Acids Research, v. 17, no. 16, p. 6463-6471.
Tautz, Diethard, Trick, Martin, and Dover, G.A., 1986, Cryptic simplicity in DNA is a major source of genetic variation: Nature, v. 322, p. 652-656.

Teshima, Hiroaki, Davidson, Angus, Kuwahara, Yasuhiro, Yokoyma, Jun, Chiba, Satoshi, Fukuda, Tatsuya, Ogimura, Hideo, and Kawata, Masakado, 2003, The evolution of extreme shell shape variation in the land snail Ainohelix edita - A phylogeny and hybrid zone analysis: Molecular Ecology, v. 12, p. 1869-1878.

Turgeon, D.D., Quinn, J.F., Jr., Bogan, A.E., Coan, E.V., Hochberg, F.G., Jr., Lyons, W.G., Mikkelsen, P.M., Neves, R.J., Roper, C.F.E., Rosenberg, Gary, Roth, Barry, Scheltema, A.H., Thompson, F.G., Vecchione, Michael, and Williams, J.D., 1998, Common and scientific names of aquatic invertebrates from the United States and CanadaMollusks (2d ed.): American Fisheries Society Special Publication 26, 526 p.

U.S. Fish and Wildlife Service, 1992a, Endangered and threatened wildlife and plants; final rule to list the Kanab ambersnail as endangered: Federal Register, v. 57, no. 75, p. 13657-13661.

U.S. Fish and Wildlife Service, 1992b, Kanab ambersnail (Oxyloma haydeni kanabensis): U.S. Fish and Wildlife Service, Endangered Species Technical Bulletin no. 17, no. $1-2$, p. 6.

U.S. Fish and Wildlife Service, 1996, Biological opinion on the effects of the spring 1996 beach-habitat building flow, Glen Canyon Dam: U.S. Fish and Wildlife Service, Denver, Colorado.

U.S. Fish and Wildlife Service, 1997, Biological opinion on the November 1997 fall test flow from Glen Canyon Dam: U.S. Fish and Wildlife Service, Denver, Colorado.

Verduin, Adriaan, 1982, How complete are diagnoses of coiled shells of regular build?-A mathematical approach: Basteria, v. 45, p. 127-142.

Vos, Pieter, Hogers, René, Bleeker, Marjo, Reijans, Martin, van de Lee, Theo, Hornes, Miranda, Frijters, Adrie, Pot, Jerina, Paleman, Johan, Kuiper, Martin, and Zabeau, Marc, 1995, AFLP — A new technique for DNA fingerprinting: Nucleic Acids Research, v. 23, no. 21, p. 4407-4414.

Wada, Shinishiro, Kawakami, Kazuto, and Chiba, Satoshi, 2011, Snails can survive passage through a bird's digestive system: Journal of Biogeography (Early View), DOI: 10.1111/j.1365-2699.2011.02559.x.

Weber, J.L., and Wong, Carmen, 1993, Mutation of human short tandem repeats: Human Molecular Genetics, v. 2, no. 8 , p. $1123-1128$. 
Wheeler, Q.D., and Platnick, N.I., 2000, The phylogenetic species concept (sensu Wheeler and Platnick), in Wheeler, Q.D., and Meier, Rudolf, eds., Species concepts and phylogenetic theory-A debate: New York, Columbia University Press, 230 p.

Wilson, A.C., Cann, R.L., Carr, S.M., George, Matthew, Gyllensten, U.B., Helm-Bychowski, K.M., Higuchi, R.G., Palumbi, S.R., Prager, E.M., Sage, R.D., and Stoneking, Mark, 1985, Mitochondrial DNA and two perspectives on evolutionary genetics: Biological Journal of the Linnean Society, v. 26, no. 4, p. 375-400.
Wilson, E.O., and Brown, W.L., Jr., 1953, The subspecies concept and its taxonomic application: Systematic Zoology, v. 2, no. 3, p. 97-111. 


\section{Glossary of Molecular Genetic Terms}

\author{
Alleles Different Forms Of A Gene, Or Region \\ Of Dna, At The Same Locus.
}

Amplicon Double-stranded DNA product generated from a PCR amplification reaction.

Amplified Fragment Length Polymorphism (AFLP) A PCR-based genetic method to detect DNA polymorphism. The method uses restriction enzymes to digest genomic DNA into restriction fragments, followed by ligation of adaptors onto the ends of the DNA fragments. A subset of the restriction fragments is selected for PCR amplification during the PCR-amplification process.

Analysis of Molecular Variance (AMOVA) A method to compare genetic variation within versus among populations.

Autosomal locus A position on a chromosome, other than a sex chromosome.

Bayesian A statistical phylogenetic treebuilding method that assigns probabilities or distributions after obtaining experimental data (posterior probability).

Bidirectional sequencing DNA sequencing from the forward and reverse directions; combining these sequences confirms the sequence because the forward and reverse sequences are not identical but are actually complementary sequences.

Bp Base pairs of deoxyribonucleic acid.

Codominant Both alleles of a gene, or region of DNA, are expressed.

Denature DNA Double-stranded DNA melts into single-stranded strands.

Diploid A double set of homologous chromosomes.

DNA Deoxyribonucleic acid, the molecular make-up of chromosomes.

DNA sequencing Sequence of nucleotide pairs along the DNA molecule.

Dominant Only one allele of a gene, or region of DNA, is expressed.

Electrophoresis Separating molecules based on different rates of travel in an electric field.
EtOH Ethanol, an alcohol used to precipitate

DNA in the process of extracting and purifying

DNA from cellular material.

Evolutionarily Significant Unit (ESU) A population of organisms that are distinct for the purpose of conservation.

Fluorometer An instrument for detecting and measuring fluorescence; for the purpose of quantifying DNA. Fluorescent dye is first bound to the DNA, and then measured to quantify the amount of DNA.

Fu's F statistic A test for population expansion. A significant Fu's $F$ means population expansion has occurred.

Genome The complete makeup of genetic material for an organism.

Haplotype Unique combination of linked mutations on a section of DNA.

Heterozygous Containing two different alleles at the same locus.

Homozygous Containing two of the same allele at the same locus.

Indel Refers to an insertion or deletion mutation.

ITS Internal transcribed spacer, refers to a piece of nonfunctional RNA (ribonucleic acid) located between structural rRNAs (ribosomal RNAs).

Kbp Kilo base pairs .

Locus The position of a specific gene, or region of DNA, on a chromosome.

Mantel test A statistical test of the correlation between two matrices, such as genetic distance and geographic distance.

Maximum Likelihood A statistical phylogenetic tree-building method used to fit a statistical model to data and to provide estimates for the model's parameters.

Maximum Parsimony (MP) A minimum evolution tree-building method used to estimate phylogenies with the fewest number of mutational steps. 
Median-joining network A phylogenetic graph used to visualize evolutionary relationships from sequences.

Microsatellite DNA locus A single location in the genome where a microsatellite occurs (tandem array of $2-6$ base pairs).

Microsatellite genotype All fragments generated from PCR of a microsatellite locus, and subsequent electrophoresis.

Mitochondrial DNA (mtDNA) DNA located in mitochondria organelle or eukaryotic cells, which converts energy from food into a form that cells can use. Mitochondrial DNA is maternally inherited and more rapidly evolving than nuclear DNA.

Mendelian inheritance How hereditary characteristics are passed from parent organisms to their offspring.

Metapopulation A group of spatially separated populations of the same species that interact at some level.

Molecular genetics Study of gene, or region of DNA, at the molecular level.

Molecular (genetic) marker An informative gene, or region of DNA, used for genetic study.

Monomorphic Having all alleles the same, with no variation.

Multilocus marker Genetic marker that simultaneously detects multiple loci throughout the genome.

Neighbor Joining (NJ) A phenetic- or geneticdistance-based method used for construction of phylogenetic trees that allows branches of the tree to have varying evolutionary rates.

Orthologous Genes evolved directly from a common ancestor.

Outgroup Group of organisms that serves as a reference group for determination of relationships of a monophyletic group of organisms (ingroup), and also forms the root of a phylogenetic tree.

Paralogous Genes evolved by duplication within a genome.
Phylogenetics A method to infer relationships among taxa, usually by building phylogenetic trees.

Polymerase Chain Reaction (PCR) Technique to make many copies of a specific region of DNA using oligonucleotide primers on each end of sequence to amplify.

Polymorphic Having many different alleles; variation among alleles.

\section{Restriction Fragment Length}

Polymorphism Variation in length of DNA fragments generated by endonuclease digestion.

Roza's value A test of neutrality for a set of DNA sequences, which tests for population growth versus population stability.

Single locus marker Genetic marker that detects only one locus in the genome at one time.

\section{Single Nucleotide Polymorphism (SNP)}

"snips" DNA sequence variant where one nucleotide differs from one individual to the next.

Species Taxonomic unit, group of organisms that are reproductively isolated from other such groups of organisms, and basic unit of biological classification.

Subspecies Taxonomic subdivision below the species level.

Tajima's D A test for population expansion or selection. A significant negative Tajima's D can mean population expansion or positive purifying selection.

Taxon A group of organisms.

Unweighted Pair Group Method with Arithmetic mean (UPGMA) A phenetic- or geneticdistance-based method used to build phylogenetic trees that assumes equal rates of evolution on all branches of the tree.

\section{Variable Number of Tandem Repeat}

(VNTR) Region of DNA whose alleles contain different numbers of tandemly repeated minisatellite oligonucleotide sequences.

Vicariance The separation of a group of organisms by a geographic barrier. 


\section{Appendix A. Genbank Accession Numbers}

Data are available for download at http://pubs.usgs/gov/sir/2013/5164/AppendixA.pdf

\section{Appendix B. DNA Sequences for Random Ambersnail Nuclear Clone 356}

Data are available for download at http://pubs.usgs/gov/sir/2013/5164/AppendixB.pdf

\section{Appendix C. DNA Sequences for Ribosomal First and Second Internal Transcribed Spacer}

Data are available for download at http://pubs.usgs/gov/sir/2013/5164/AppendixC.pdf 
This page intentioanlly left blank. 
Publishing support provided by the U.S. Geological Survey

Publishing Network, Tacoma Publishing Service Center

For more information concerning the research in this report, contact the Leader, Arizona Cooperative Fish and Wildlife Research Unit U.S. Geological Survey

325 Biosciences East

Tucson, Arizona 85721

http://www.coopunits.org/Arizona/ 
